2017-6

\title{
Conformational Studies of Gram-Negative Bacterial Quorum Sensing 3-oxo N-acyl Homoserine Lactone Molecules
}

\author{
Darren Crowe \\ Technological University Dublin \\ Alan Nicholson \\ Technological University Dublin \\ Adrienne Fleming \\ Technological University Dublin
}

See next page for additional authors

Follow this and additional works at: https://arrow.tudublin.ie/ittsciart

Part of the Medicinal-Pharmaceutical Chemistry Commons, Organic Chemistry Commons, and the Physical Chemistry Commons

\section{Recommended Citation}

Kelleher, F. et al. (2017) Conformational studies of Gram-negative bacterial quorum sensing 3-oxo N-acyl homoserine lactone molecules, Bioorganic and Medicinal Chemistry Vol. 25, no. 16, 15 August 2017, Pages 4285-4296 DOI: 10.1016/j.bmc.2017.06.006

This Article is brought to you for free and open access by the School of Science and Computing at ARROW@TU Dublin. It has been accepted for inclusion in Articles by an authorized administrator of ARROW@TU Dublin. For more information, please contact arrow.admin@tudublin.ie, aisling.coyne@tudublin.ie, gerard.connolly@tudublin.ie.

Funder: Irish Government; Irish Research Council

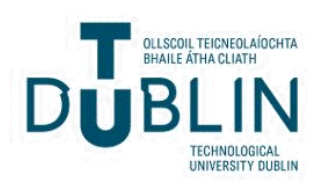




\section{Authors}

Darren Crowe, Alan Nicholson, Adrienne Fleming, Ed Carey, Goar Sanchez-Sanz, and Fintan Kelleher

This article is available at ARROW@TU Dublin: https://arrow.tudublin.ie/ittsciart/38 
Conformational studies of Gram-negative bacterial quorum sensing 3-oxo $N$-acyl homoserine lactone molecules

Darren Crowe, ${ }^{\mathrm{a}}$ Alan Nicholson, ${ }^{\mathrm{a}}$ Adrienne Fleming, ${ }^{\mathrm{a}}$ Ed Carey, ${ }^{\mathrm{a}}$ Goar Sánchez-Sanz ${ }^{\mathrm{b}}$ and Fintan Kelleher ${ }^{\mathrm{a} *}$

${ }^{a}$ Molecular Design and Synthesis Group, Centre of Applied Science for Health, Institute of Technology Tallaght, Dublin 24, Ireland.

${ }^{\mathrm{b}}$ Irish Centre of High-End Computing, Grand Canal Quay, Dublin 2, Ireland

Corresponding Author: $\quad$ Fintan Kelleher

Address: Department of Science,

Institute of Technology Tallaght,

Tallaght,

Dublin 24,

Ireland.

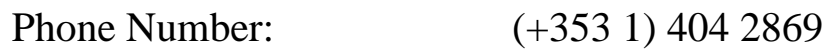

e-mail address: $\quad$ fintan.kelleher@ittdublin.ie

Graphical abstract:

Conformational studies of Gram-negative bacterial quorum sensing 3-oxo $N$-acyl homoserine lactone molecules

Darren Crowe, Alan Nicholson, Adrienne Fleming, Ed Carey, Goar Sánchez-Sanz and Fintan Kelleher*<smiles>[R]CC(=O)CC(=O)N[C@@H]1CCOC1=O</smiles>

Extended conformation<smiles></smiles>

H-bonded conformation

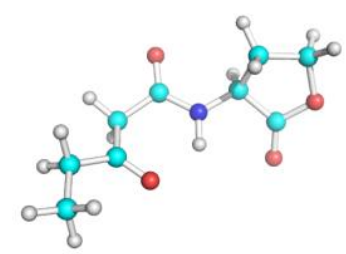


Conformational studies of Gram-negative bacterial quorum sensing 3-oxo $N$-acyl homoserine lactone molecules

Darren Crowe, ${ }^{\mathrm{a}}$ Alan Nicholson, ${ }^{\mathrm{a}}$ Adrienne Fleming, ${ }^{\mathrm{a}}$ Ed Carey, ${ }^{\mathrm{a}}$ Goar SánchezSanz ${ }^{\mathrm{b}}$ and Fintan Kelleher ${ }^{\mathrm{a} *}$

${ }^{a}$ Molecular Design and Synthesis Group, Centre of Applied Science for Health, Institute of Technology Tallaght, Dublin 24, Ireland.

${ }^{\mathrm{b}}$ Irish Centre of High-End Computing, Grand Canal Quay, Dublin 2, Ireland

\begin{abstract}
:
In their ${ }^{1} \mathrm{H}$ NMR spectra in $\mathrm{CDCl}_{3}$ 3-oxo- $N$-acyl homoserine lactones (OHLs) show significant downfield chemical shifts of the amide N-H proton when compared to the parent $\mathrm{N}$-acyl homoserine lactones (AHLs). NMR spectroscopic and DFT calculation studies have shown that this is most likely due to the presence of a stabilising intramolecular $\mathrm{H}$-bond from the $\mathrm{N}-\mathrm{H}$ to the 3-oxo group. The ${ }^{1} \mathrm{H}$ NMR spectra also show evidence for the enol tautomers and that the amount of enol present for a range of OHLs is $4.1-4.5 \%$ in $\mathrm{CDCl}_{3}$ and $6.5-7.2 \%$ in $\mathrm{CD}_{3} \mathrm{CN}$. In contrast, DFT calculations show that the lowest energy enol tautomer and the keto tautomer are of equal energy in the gas phase, but that the keto tautomer is more stable in chloroform, acetonitrile and water solution. The calculations also show that there is no evidence for any $n \rightarrow \pi^{*}$ or $\mathrm{C} 5 \mathrm{H}$-bonding interactions being present in either the lowest energy keto or enol tautomer of the OHLs in solution or the gas phase, which is in contrast to the reported solid-state structure.
\end{abstract}

\title{
Keywords:
}

Homoserine lactones; $\beta$-keto amide; DFT calculations; keto-enol tautomers; quorum sensing

\section{Introduction}

Antimicrobial resistance (AMR), particularly among Gram-negative species such as Klebsiella species, E. coli species and Pseudomonas aeruginosa, has been identified by the World Health Organisation as one of the greatest current threats facing the 
health of mankind. ${ }^{1}$ New antibiotics are therefore continuously required to combat the threat of AMR, with as many different approaches as possible being used. Many bacterial species use small molecules or peptides to communicate with each other, either within a bacterial species or between species. ${ }^{2}$ The concentration level of these communication molecules (autoinducers) is dependent on the number of bacteria present. When a sufficient number of bacteria are present a "quorum" is reached and the bacteria change their behaviour from that of a single-celled organism to multicelled. This quorum sensing causes an alteration in gene expression which can lead to changes in the virulence factors of the bacteria, and in some cases leads to biofilm formation. ${ }^{2}$ Therefore inhibition of quorum sensing may be an important method for halting the spread of bacterial infections, and very importantly is bacteriostatic rather bactericidal in nature, which may help to reduce incidences of the development of AMR.

In many clinically relevant Gram-negative bacteria these communication molecules are $\mathrm{N}$-acyl L-homoserine lactones (AHLs) and 3-oxo $\mathrm{N}$-acyl L-homoserine lactones (OHLs), as seen Figure 1.<smiles>CC(C)(C)C(=O)N[C@H]1CCOC1=O</smiles>

Acyl homoserine lactones (AHLs)<smiles>CCCC(C)CC(=O)N[C@@H]1CCOC1=O</smiles>

3-Oxo acyl homoserine lactones (OHLs)

Figure 1: Structures of AHL and OHL bacterial communication molecules ${ }^{2}$

Structurally they consist of a $\gamma$-lactone head-group linked to a hydrocarbon chain via an amide (AHLs) or $\beta$-ketoamide linkage (OHLs). The range of AHLs and OHLs found in nature differ mainly in the length of the hydrocarbon chain and whether it is branched, unsaturated, hydroxylated or indeed combinations of these. However, the amide or $\beta$-ketoamide linkage is ubiquitous. A number of groups have studied analogues of both AHLs and OHLs as agonists and antagonists of quorum sensing in a range of clinically important bacterial species, such as $P$. aeruginosa and $A$. baumannii. ${ }^{3}$ These analogues have included changes to the lactone head-group, the 
amide or $\beta$-ketoamide linker and the hydrocarbon chains, and some very active inhibitors have been identified. ${ }^{4}$ Recently, Blackwell has used receptor mutation studies to detail the important hydrogen bond (HB) interactions for binding of the both native and non-native molecules with the LasR receptor. ${ }^{5}$ The Raines group used computational methods in vacuo to identify possible $n \rightarrow \pi^{*}$ interaction in AHLs, ${ }^{6}$ which were recently confirmed by the Prabhakaran group. ${ }^{7}$ These reports studied how the $\mathrm{n} \rightarrow \pi^{*}$ interactions might influence the stability and reactivity of AHL molecules. More recently Raines reported the solid-state x-ray crystal structure of the OHL, $\mathrm{N}$-(3oxobutanoyl)-L-homoserine lactone, which showed evidence for two stabilising $\mathrm{n} \rightarrow \pi^{*}$ interactions between the ketone carbonyl to amide carbonyl and from the amide carbonyl to the lactone carbonyl (Figure 2). ${ }^{8}$ In addition the crystal packing shows intermolecular H-bonding between the amide carbonyl oxygen of one molecule with the amide $\mathrm{N}-\mathrm{H}$ of the next molecule in the unit cell. An examination of the published x-ray structures in the Protein Database (PDB) ${ }^{9}$ of receptor-bound OHLs shows that the preferred bound conformation is for an extended molecular structure (Figure 2). The fact that such significantly different conformations are observed would suggest that the molecules are relatively flexible allowing many possible conformations to be achieved. How exactly any of these conformations directly relate to the actual bioactive conformation is not clear, as both the receptor-bound and solidsate structures might just be the conformations that led to crystallisation under the experimental conditions used.

\section{Results and discussion}

We were interested in studying the conformational preferences for OHLs, to see how the extra carbonyl group might impact the overall preferred conformations of these molecules. Since Blackwell showed the importance of H-bonding of OHLs to their receptors ${ }^{5}$ it would be of interest to see whether there is any evidence for HBs within these molecules in vacuo and/or in solution, in the absence of their receptors. If such HBs are possible there is no guarantee that they would be also be present when the OHLs are receptor-bound as the HBs described by Blackwell, between the OHL and the receptor amino acid residues and/or water molecules within the binding site, are likely to be more important. However, a deeper understanding of the overall structural 
preferences of OHLs may possibly allow for the better design of quorum sensing inhibitors in the future.

\section{Extended conformation}

$$
\text { (x-ray receptor bound })^{5}
$$<smiles>[R]CC(=O)CC(=O)N[C@@H]1CCOC1=O</smiles><smiles>C=C</smiles>

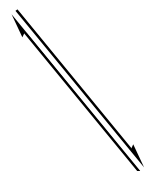

B

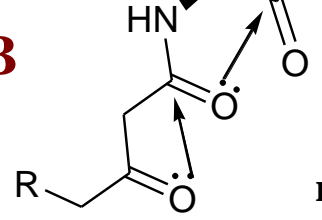

H-bonded conformation

(Solution and computational - this work)

Figure 2: Some possible conformations of OHLs $(\mathrm{R}=\mathrm{H} \text { or alkyl })^{5,8}$

\subsection{NMR studies of OHL molecules}

The ${ }^{1} \mathrm{H}$ NMR spectra, as measured in dilute $1 \mathrm{mM}$ solutions in $\mathrm{CDCl}_{3}$, for a number of commercially available OHLs $\left(\mathrm{C}_{6}-\mathrm{C}_{14}\right.$ side-chains $)$ all showed a downfield chemical shift for the amide $\mathrm{N}-\mathrm{H}$ protons at 7.6-7.7 ppm (Figure 3). $\mathrm{CDCl}_{3}$ was chosen as the solvent for the NMR studies because a recent report from the Mavri group used the dielectric constant of the internal protein environment as $\sim 4.0,{ }^{10}$ as previously reported by the Himo group. ${ }^{11}$ This value is very close to that of chloroform with a dielectric constant of 4.81 , while the dielectric constant of water (biological solvent) is $\sim 78.4$. 


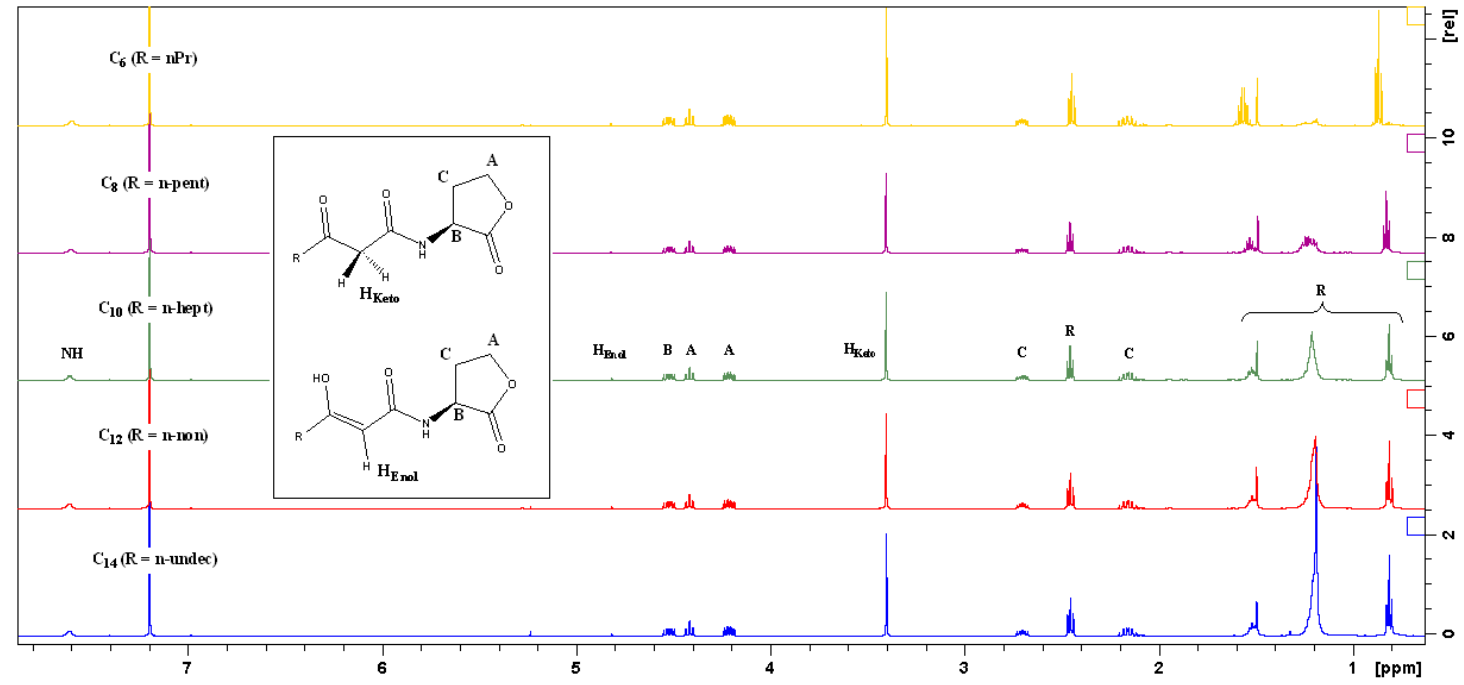

Figure 3. Stacked ${ }^{1} \mathrm{H}$ NMR spectra of $\mathrm{C}_{6}-\mathrm{C}_{14}$ OHLs in $\mathrm{CDCl}_{3}$ at 7 days

The chemical shifts obtained for the OHLs were all consistent with those reported in the literature for these compounds. ${ }^{4,12}$ The observed downfield chemical shift would be expected if the $\mathrm{N}-\mathrm{H}$ proton was $\mathrm{H}$-bonded to the 3-oxo group of the side-chain (Figure 2). Further evidence for the presence, in $\mathrm{CDCl}_{3}$ solution, of the $\mathrm{H}$-bonded keto conformer $\mathbf{C}$ comes from a comparison of the chemical shift of the amide N-H proton in the 3-oxo AHLs with the values reported (6.0-6.2 ppm) for the analogous AHL compounds which lack the 3 -oxo group. ${ }^{12}$ The solution concentration used was $1 \mathrm{mM}$ which is in contrast to the solution NMR studies by the Prabhakaran group on the analogous AHL molecules where concentrations of $10 \mathrm{mM}$ for ${ }^{1} \mathrm{H}$ NMR and $60 \mathrm{mM}$ for ${ }^{13} \mathrm{C}$ NMR were used. ${ }^{7}$ Raines described that similar peptides to those used in their study of C5 H-bonds were shown to be monomeric at a concentration of $10 \mathrm{mM} .^{13,14}$ Although the OHLs being studied here are not peptides there is no reason to think that at a concentration of an order of magnitude lower, i.e. $1 \mathrm{mM}$, that the molecules would be anything but monomeric in $\mathrm{CDCl}_{3}$ solution. The presence of an intramolecular, rather than intermolecular, $\mathrm{HB}$ was confirmed when the ${ }^{1} \mathrm{H}$ NMR spectra of the $\mathrm{C}_{8}-\mathrm{OHL}$ at concentrations of $1 \mathrm{mM}, 2.5 \mathrm{mM}, 5 \mathrm{mM}$ and $10 \mathrm{mM}$ (Figure 4) were acquired and the observed chemical shift of the $\mathrm{N}-\mathrm{H}$ proton in each case was consistent at $7.641 \mathrm{ppm}, 7.642 \mathrm{ppm}, 7.643 \mathrm{ppm}$ and $7.644 \mathrm{ppm}$, respectively. 


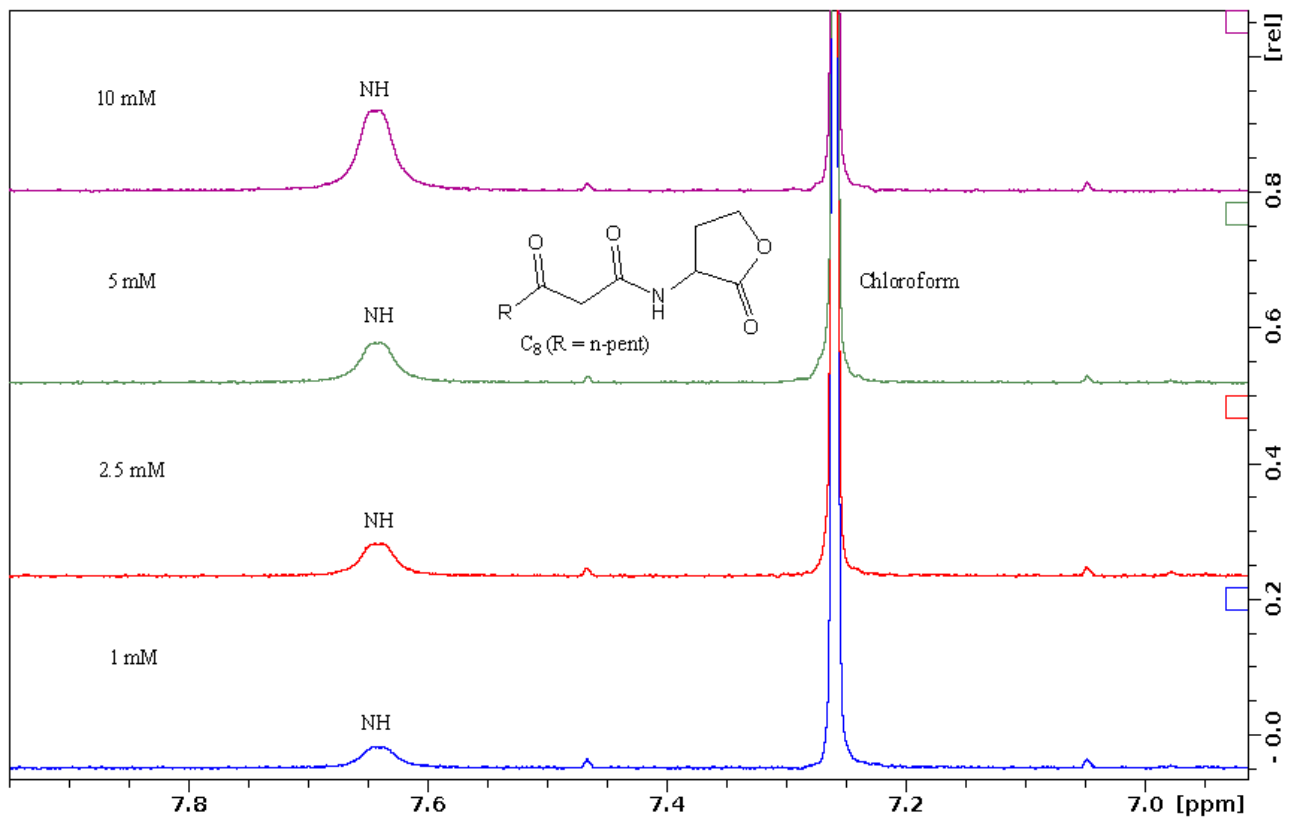

Figure 4. ${ }^{1} \mathrm{H}$ NMR stack of $\mathrm{C}_{8}-\mathrm{OHL} \mathrm{N}-\mathrm{H}$ region at $1-10 \mathrm{mM}$ concentrations in $\mathrm{CDCl}_{3}$

\subsection{Computational studies of a simple OHL molecule}

Density Functional Theory (DFT) calculations, at the B3LYP 6-311++G(d,p) computational level in vacuo, of a simple $\mathrm{OHL}$ structure (Figure $2, \mathrm{R}=\mathrm{CH}_{3}$ ) gave some unexpected results. A number of repetitions of calculations, involving changes to the starting orientation of the side-chain, by rotation around the amide carbonyl to $\mathrm{C}_{2}$ carbon bond and lactone $\alpha$-carbon to amide nitrogen (Figure 2) were undertaken. The array of starting conformations employed included those seen in the x-ray crystal structure of an isolated $\mathrm{OHL},{ }^{8}$ as well as receptor bound conformations. ${ }^{9}$ Any attempt to optimise conformation A resulted in a distorted structure with the two carbonyl groups pointing to different directions provoked by the repulsion between both groups (Figure 5). The minimum energy conformation found was quite different to the receptor bound conformation. ${ }^{9}$ 


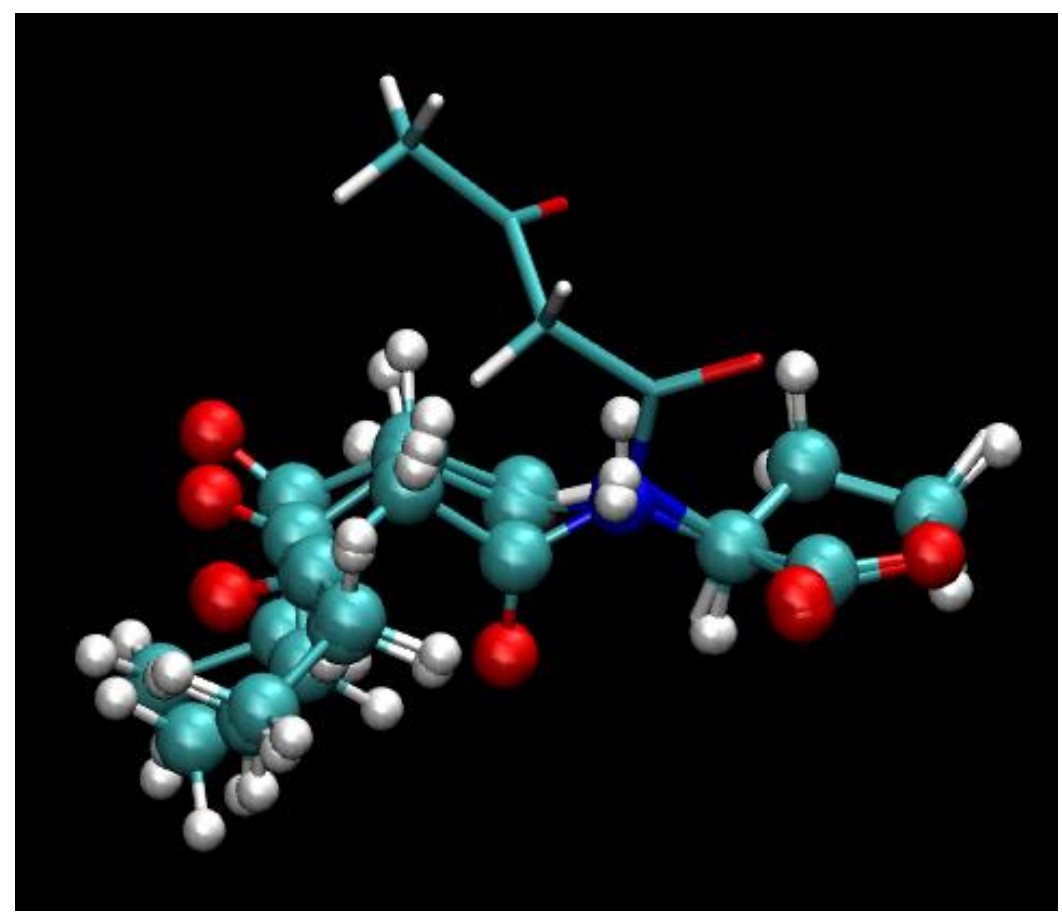

Figure 5. Overlay of the gas phase and solvent PCM model calculated structures of conformer A (balls and sticks) with the published crystal structure ${ }^{8}$ (licorice).

Regardless of the starting conformation of the side-chain the lowest energy conformation obtained (C) was a compact structure stabilised by one intramolecular HB (see Table S1 for full details). This HB (2.049 A, vide infra) is formed between the amide $\mathrm{N}-\mathrm{H}$ and the 3-oxo carbonyl group. Although there is the possibility of a C5 type H-bond (between the N-H and the oxygen atom of the lactone), which is now considered to be very important in stabilising peptide and protein structures, ${ }^{13,14}$ no evidence of such an interaction was found either by means of Natural Bond Orbital (NBO) calculations ${ }^{15}$ or by Atoms In Molecules (AIM) ${ }^{16}$ results.

The HB found in conformer $\mathbf{C}$ is an intramolecular HB forming a 6-membered ring, with the O--N distance being $2.793 \AA$ and an O--H-N angle of $128.2^{\circ}$. The HB is characterised (by AIM) by the presence of a bond critical point (BCP) between both interacting atoms with an electron density $\left(\rho_{\mathrm{BCP}}\right)$ of 0.0224 a.u., which is in the range of HBs. ${ }^{16}$ The Laplacian value $\left(\nabla^{2} \rho\right)$ of that HB shows that this interaction is in the closed shell regimen (see Table S1). It has been stated that the negative value of the total electron energy density at the $\mathrm{BCP}, \mathrm{H}_{\mathrm{BCP}}$, confirms the covalent character of the corresponding interaction. ${ }^{17}$ Furthermore, positive and small values of the electron 
total energy, $\mathrm{H}_{\mathrm{BCP}}$, indicates small covalent character of the interactions. According to Jeffrey's classification this would be moderately strong HB. ${ }^{18}$

To study conformer B in more detail we have carried out PCM solvent calculations at the B3LYP/6-311++G(d,p) computational level, using water $(\varepsilon=78.4)$, acetonitrile $(\varepsilon=35.7)$ and chloroform $(\varepsilon=4.7)$. In all three cases, conformer $\mathbf{C}$ was the lowest energy conformation found (Table 1). The HB between the N-H and the oxygen atom of 3-oxo carbonyl groups occurs with $\mathrm{H}$... O distances of 1.946, 1.949 and $1.968 \AA$ for water, acetonitrile and chloroform, respectively (vide infra). The evolution of the intramolecular distance is coherent with the polarity of the solvent considered, i.e. the larger dielectric constant, the shorter HB distance.

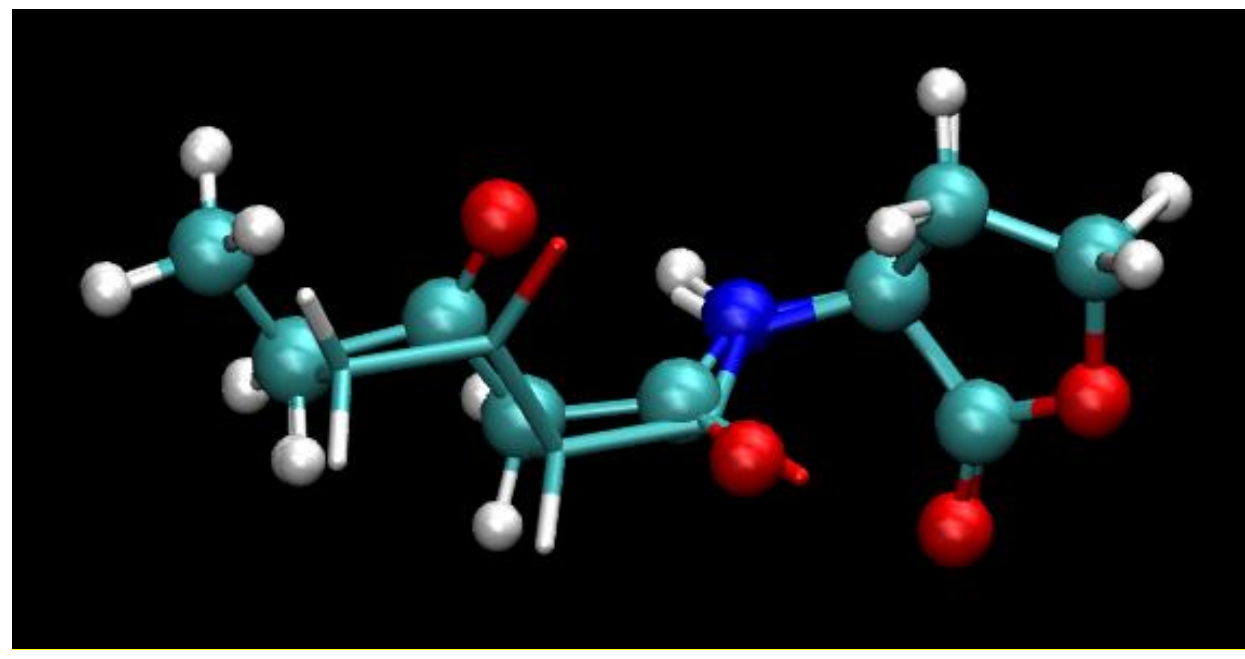

Figure 6. Overlay of the calculated structures of conformer $\mathbf{B}$ in water and acetonitrile (balls and sticks), with the published crystal structure conformation ${ }^{8}$ (licorice)

Regarding the X-ray conformation $\mathbf{B}$ reported by Raines, ${ }^{8}$ any attempt to optimise it in the gas phase or chloroform solution shows it reverting to conformer C. However, conformation B was obtained as an energy minimum in the polar solvents acetonitrile and water (Figure 6) but $\mathbf{C}$ was still the lowest energy conformer obtained (Table 1).

Table 1. Relative energies (in $\mathrm{kcal} / \mathrm{mol}$ ), at the B3LYP/6-311++G(d,p) computational level, for the conformers A-C in the gas phase, chloroform, acetonitrile and water solvent models, including zero-point correction. 


\begin{tabular}{ccccc}
\hline Conformer & Gas Phase & Chloroform & Acetonitrile & Water \\
\hline $\mathbf{A}$ & 2.27 & 1.60 & 2.26 & 1.70 \\
$\mathbf{B}$ & $1.64^{\mathrm{a}}$ & $1.63^{\mathrm{a}}$ & 1.09 & 1.77 \\
$\mathbf{C}$ & $\mathbf{0 . 0 0}$ & $\mathbf{0 . 0 0}$ & $\mathbf{0 . 0 0}$ & $\mathbf{0 . 0 0}$
\end{tabular}

${ }^{a}$ In gas phase and chloroform, conformer $\mathbf{B}$ does not present two simultaneous $n \rightarrow \pi^{*}$ interactions but the structure exists as minimum.

For conformer $\mathbf{B}$ the intramolecular distance between the $\mathrm{O}$ electron donor of the amide group and carbon atom of the lactone carbonyl group, acting as an acceptor (2.810 and $2.913 \AA$ in acetonitrile), are less than the sum of the van der Waal's radii (3.22 A). Besides, NBO analyses reveal a small donation $[\mathrm{E}(2)=1.01 \mathrm{kcal} / \mathrm{mol}]$ from the $\mathrm{O}$ lone pair of the amide carbonyl oxygen into the $\pi^{*} \mathrm{CO}$ antibonding orbital of the lactone carbonyl. However, AIM results (Figure 7a) do not show any BCP between the corresponding interacting atoms. Nevertheless, it is well-known that in some cases, the absence of a BCP does not indicate the absence of an interaction. Additionally, Non-Covalent Interaction (NCI) plots ${ }^{19}$ show (Figure $7 b$ ) a green area between the amide oxygen donor and the lactone carbonyl, indicating a weak $\left(\lambda_{2} \approx 0\right)$ interaction, as seen in the $\mathrm{x}$-ray crystal structure reported by Raines. ${ }^{8}$ This type of stabilising interaction was reported in different systems and the interaction is reminiscent of the Bürgi-Dunitz trajectory for nucleophilic additions to carbonyl groups and eventually should provoke pyramidalisation of the acceptor carbonyl group. ${ }^{20-23}$ The conformation $\mathbf{B}$ obtained in water is almost identical to that found for acetonitrile (see Figure 6 and Figure 7). 

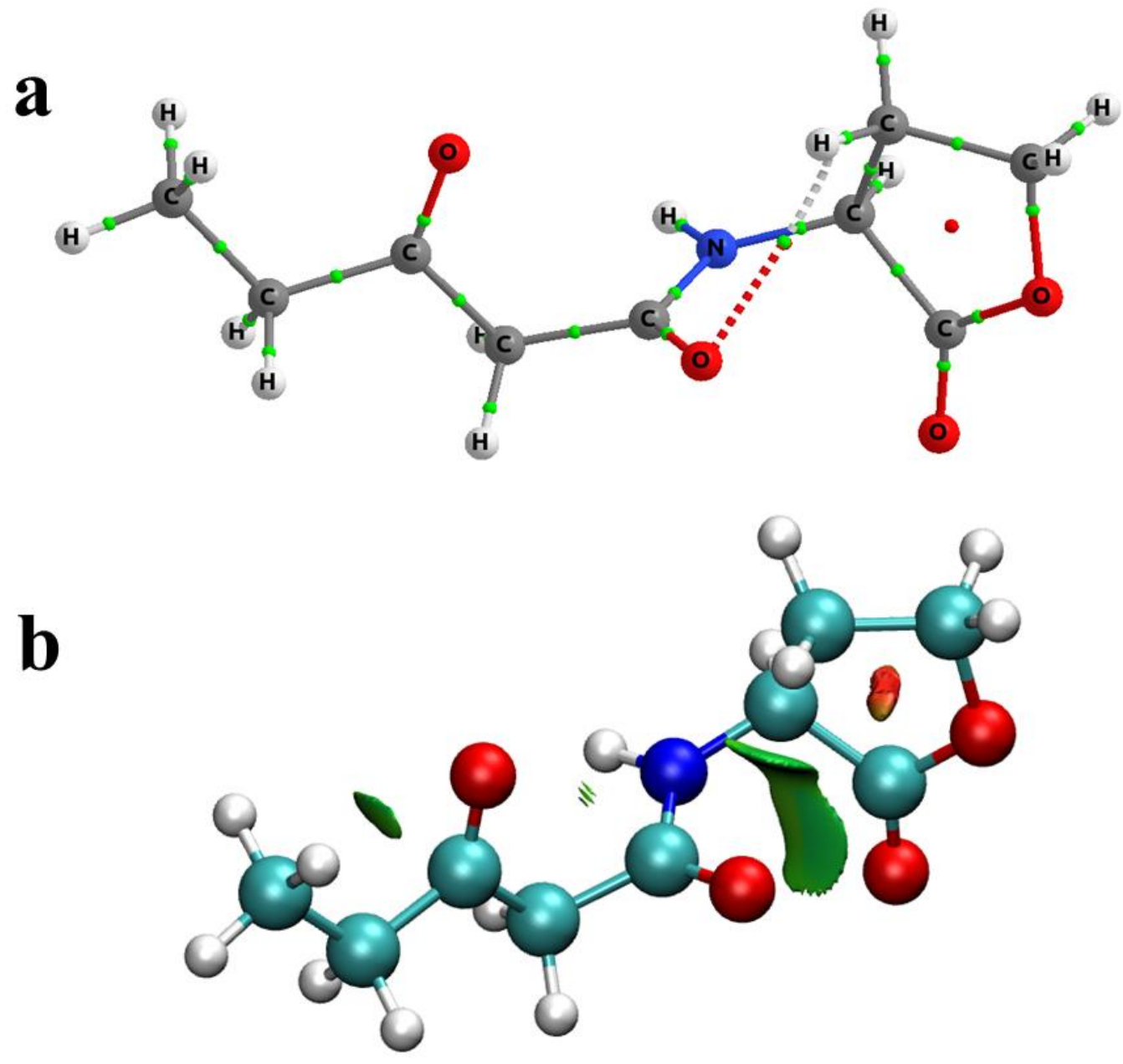

Figure 7. a) Molecular graph corresponding to the conformer $\mathbf{B}$ structures at the B3LYP/6-311++G(d,p) computational level in acetonitrile. Green and red dot corresponds to the bond and ring critical points respectively; b) Non-covalent interaction (NCI) plots for conformation $\mathbf{B}$ in acetonitrile. Green areas correspond to $\lambda_{2} \approx 0$ (weak). $\lambda_{2}$ is one of the three eigenvalues of the electron density Hessian with $\lambda_{1} \leq \lambda_{2} \leq \lambda_{3}$.

Raines recently described the cis and trans conformers of a $\beta$-keto amide of proline methyl ester (Figure 8a), where the trans conformer was stabilised by an $n \rightarrow \pi^{*}$ interaction. $^{24}$ It is well known that in proline there is a very low energy barrier between the cis and trans rotameric conformers of the tertiary amide. This system is not a direct comparison to the OHL molecules in this study because OHLs are 
secondary amides with an N-H which is capable of intramolecular $\mathrm{H}$-bonding. If conformer $\mathbf{B}$ was present in solution then it would be expected that the chemical shift of the N-H proton would be similar to that of the AHLs (6.0-6.2 ppm), which both Raines and Prabhakaran reported to contain stabilisation by an $n \rightarrow \pi^{*}$ interaction (Figure 8b). ${ }^{6,7}$

(a)
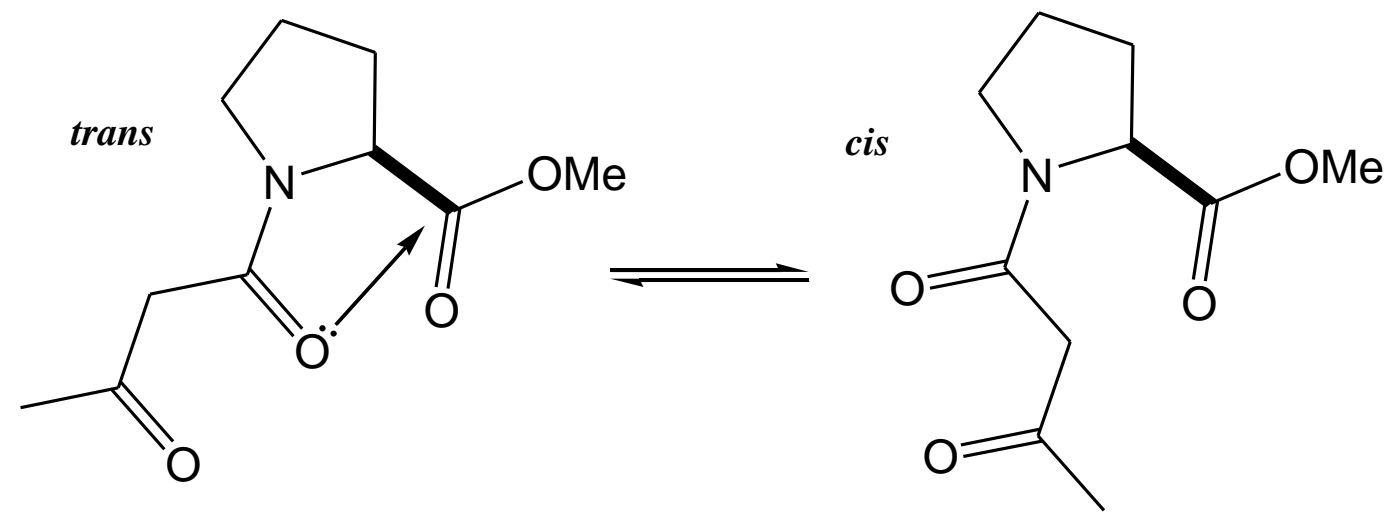

(b)
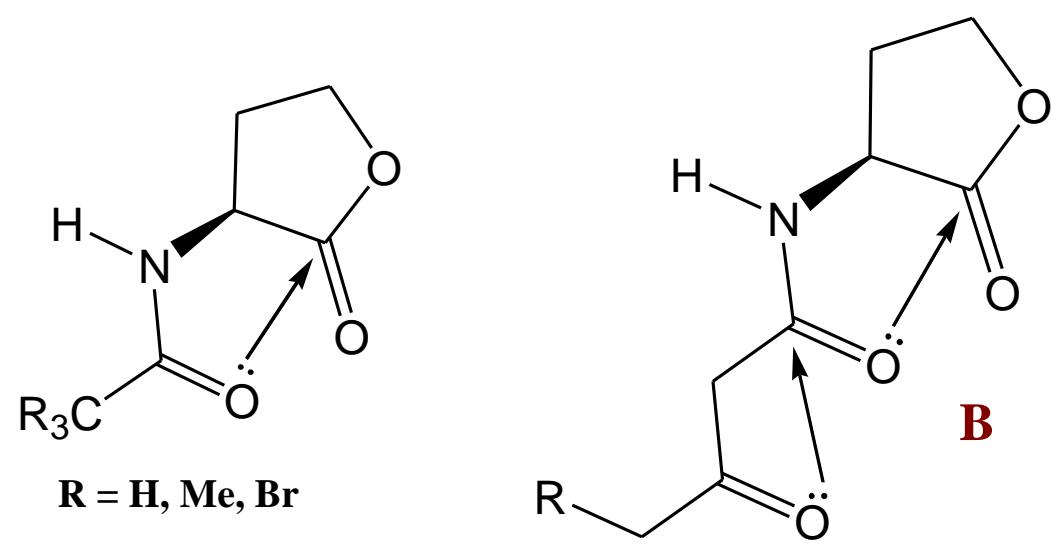

Figure 8. (a) Cis and trans conformers of $\beta$-keto amides of proline methyl ester, ${ }^{23}$ and (b) comparison of $\mathrm{n} \rightarrow \pi^{*}$ stabilised conformers of AHLs ${ }^{6,7}$ versus conformer $\mathbf{B}$

\subsection{Keto-enol tautomerism in OHLs}

As stated previously x-ray structural analyses of OHLs bound to their native receptors (e.g. LasR and TraR) have been reported, ${ }^{5,9,25}$ and these have shown that the OHL autoinducers are bound in an extended keto form, with no evidence of any enol form, or other keto conformer (e.g. conformer $\mathbf{C}$ ), being present. In order to try to get an 
understanding of the possible relative ratios of keto and enol forms of the OHLs, computational and solution NMR studies were undertaken.

\subsubsection{Keto-enol tautomeric NMR studies for OHLs}

The measurement of keto-enol tautomeric ratios by ${ }^{1} \mathrm{H}$ NMR spectroscopy for $\beta$ diketones and $\beta$-keto esters is well known, ${ }^{26}$ but the corresponding studies for $\beta$ ketoamides are far less numerous, with only a few examples having been reported. ${ }^{27}$ In most of the cases reported the $\beta$-ketoamides contain aromatic groups which are in conjugation with the enol tautomer, thus affecting significantly the observed equilibrium keto:enol ratio. Raines also described the keto and enol tautomers of the $\beta$-keto amide of proline methyl ester (Figure 5), which showed an overall enol content (cis and trans) of $>20 \% .{ }^{24}$ Thus far there have been no reports on studies of the ketoenol tautomeric ratios of the OHL autoinducers in solution. To the best of our knowledge there has been only one report, from the Kline group, on the synthesis of analogues which directly mimicked the keto and enol forms, but these showed no biological activity. ${ }^{28}$

A closer examination of the ${ }^{1} \mathrm{H}$ NMR spectra of all the OHLs in $\mathrm{CDCl}_{3}$ showed evidence for the presence of small quantities of the enol tautomers of the $\beta$-keto amide moiety (Figure 9). ${ }^{1} \mathrm{H}$ NMR spectroscopy was chosen as the method to measure the keto-enol tautomeric equilibrium constants of the same five $\left(\mathrm{C}_{6}, \mathrm{C}_{8}, \mathrm{C}_{10}, \mathrm{C}_{12}\right.$ and $\mathrm{C}_{14}$ ) naturally occurring OHLs, with the experiments being conducted in both $\mathrm{CDCl}_{3}$ solution, which mimics the protein binding site, and the polar aprotic $\left(\mathrm{CD}_{3} \mathrm{CN}\right)$ solvent at a concentration of $1 \mathrm{mM}$. Due to a lack of solubility (cloudiness of solutions) it was not possible to run the spectra in DMSO-d6, a solvent consistently used for tautomeric studies of $\beta$-keto amides, esters and $\beta$-diketones reported in the literature. ${ }^{16,17}$ Spectra were acquired immediately after preparation of the solution $\left(\mathrm{T}_{0}\right)$, and again at seven days $\left(\mathrm{T}_{7}\right)$, in order to make sure that equilibrium had been reached, in each case. Figure 6 shows the stacked spectra of the OHLs with $\mathrm{C}_{6}-\mathrm{C}_{14}$ side-chains in $\mathrm{CDCl}_{3}$ at the $\mathrm{T}_{7}$ timepoint (see Supporting Information for spectra in $\left.\mathrm{CD}_{3} \mathrm{CN}\right)$ 


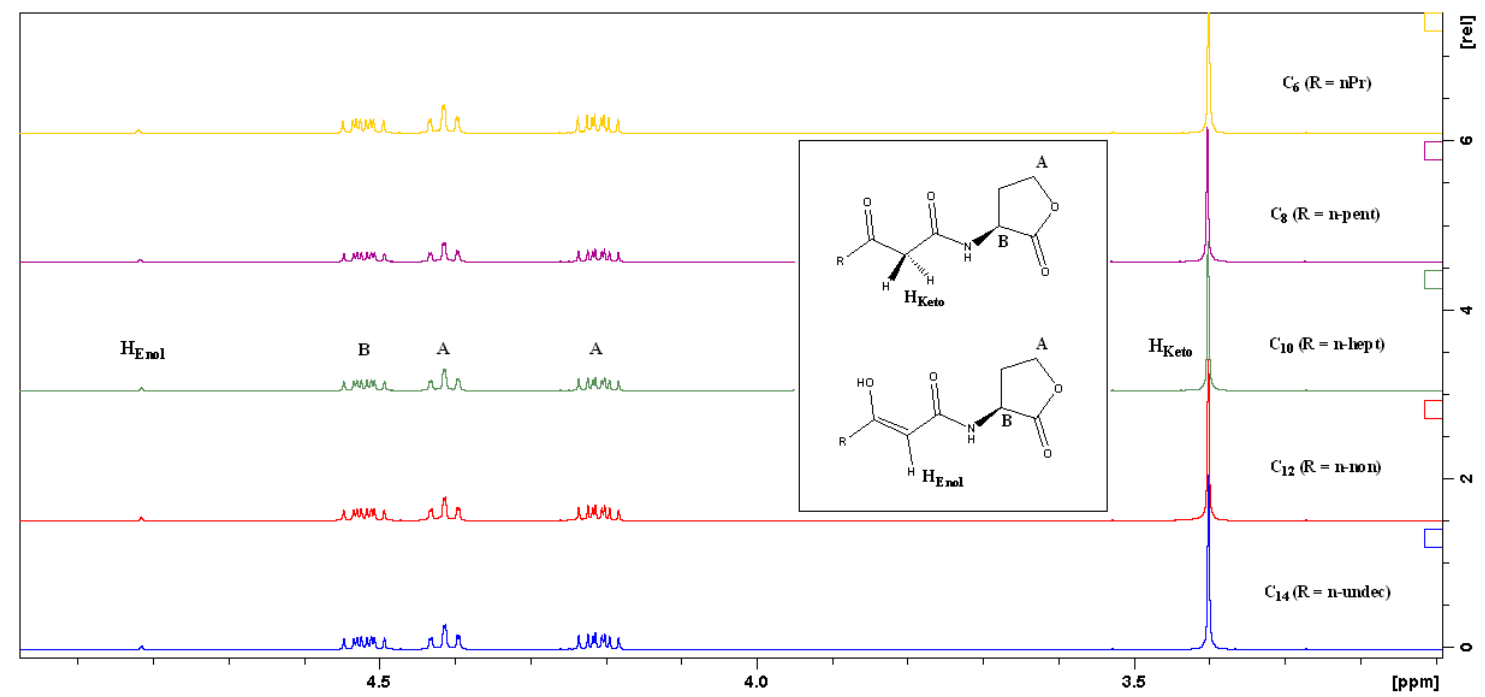

Figure 9. Stacked ${ }^{1} \mathrm{H}$ NMR spectra of $\mathrm{C}_{6}-\mathrm{C}_{14}$ OHLs in $\mathrm{CDCl}_{3}$ at 7 days, showing signals due to both the keto and enol tautomers

In each case, the integration of the $\beta$-ketoamide $\alpha$-methylene peak was measured and compared to the integration (x2) for the vinyl hydrogen peak in the enol tautomer. This allowed the tautomeric equilibrium constant $\left(\mathrm{K}_{\mathrm{T}}\right)$ and \% enol values to be calculated (Table 2). The results show that the $\%$ enol in $\mathrm{CDCl}_{3}$ is between 4.1 and $4.5 \%$, while it is slightly higher in the more polar $\mathrm{CD}_{3} \mathrm{CN}$ solvent $(6.5-7.2 \%)$. The chemical shift of the N-H proton showed a slight movement upfield to $\sim 7.2 \mathrm{ppm}$ in the $\mathrm{CD}_{3} \mathrm{CN}$ solutions.

Table 2. Equilibrium \% enol and $\mathrm{K}_{\mathrm{T}}$ values for $\mathrm{C}_{6}-\mathrm{C}_{14} \mathrm{OHLs}$ in $\mathrm{CDCl}_{3}$ and $\mathrm{CD}_{3} \mathrm{CN}$

\begin{tabular}{|c|c|c|c|}
\hline Solvent & Chain Length & \% enol $\left.\mathbf{~}_{\mathbf{7}}\right)$ & $\mathbf{K}_{\mathbf{T}}$ \\
\hline \multirow{4}{*}{$\mathbf{C D C l}_{3}$} & $\mathrm{C}_{6}$ & 4.51 & 0.047 \\
\cline { 2 - 4 } & $\mathrm{C}_{8}$ & 4.18 & 0.044 \\
\cline { 2 - 4 } & $\mathrm{C}_{10}$ & 4.08 & 0.043 \\
\cline { 2 - 4 } & $\mathrm{C}_{12}$ & 4.21 & 0.044 \\
\cline { 2 - 4 } & $\mathrm{C}_{14}$ & 4.34 & 0.045 \\
\hline \hline \multirow{4}{*}{$\mathbf{C D}_{3} \mathbf{C N}$} & $\mathrm{C}_{6}$ & 6.81 & 0.073 \\
\cline { 2 - 4 } & $\mathrm{C}_{8}$ & 7.19 & 0.077 \\
\cline { 2 - 4 } & $\mathrm{C}_{10}$ & 6.61 & 0.071 \\
\cline { 2 - 4 } & $\mathrm{C}_{12}$ & 6.50 & 0.070 \\
\cline { 2 - 4 } & $\mathrm{C}_{14}$ & 6.98 & 0.075 \\
\hline
\end{tabular}

In a manner similar to the $\mathrm{N}-\mathrm{H}$ proton, the chemical shift of the enol O-H did not change with varying concentration (see Figure S2 in supporting information), being observed at 13.215-13.217 ppm over the 1-10 $\mathrm{mM}$ concentration range. This 
demonstrates that the enol $\mathrm{HB}$, like the $\mathrm{N}-\mathrm{H}$ of the keto tautomer, is also intramolecular in nature.

\subsubsection{Computational studies of OHL keto and enol tautomers}

DFT calculations were performed in vacuo, and in a PCM solvent model, to find the relative energy of the keto tautomer $\mathbf{A}$ compared to a series of isomeric and rotameric enol tautomers (see Figure 10 and Supporting Information). The starting conformation for the first enol studied was the enol form of conformer $\mathbf{B}$, where the $n \rightarrow \pi^{*}$ interaction between the oxygen of the keto group and the amide carbonyl group was replaced with a 6-membered ring $\mathrm{HB}$ from the $\mathrm{O}-\mathrm{H}$ to the oxygen atom of the amide carbonyl group. However, the energy minimised structure obtained was conformer $\mathbf{D}$, with a 6-membered ring formed through an intramolecular $\mathrm{HB}$ with a $\mathrm{H} \cdots \mathrm{O}$ distance of $1.674 \AA$ and a $147.9^{\circ} \mathrm{O}-\mathrm{H} \cdots \mathrm{O}$ angle in vacuo (see Table S1), confirming the solution NMR results. Even shorter $\mathrm{O} \cdots \mathrm{H}$ distances were found in the solvent environment, 1.669, 1.669, $1.671 \AA$ for water, acetonitrile and chloroform, respectively. Furthermore, the large value of the electron density at the $\mathrm{BCP}$, in conjunction with the negative value of the $\mathrm{H}_{\mathrm{BCP}}$, indicates a strong $\mathrm{HB}$ with partial covalent character. However, it is worth mentioning that in vacuo, and in the nonpolar solvent chloroform, the amide $\mathrm{N}-\mathrm{H}$ bond and $\mathrm{C}=\mathrm{O}$ carbonyl group of the lactone remain parallel, i.e. the $\mathrm{H}-\mathrm{N}-\mathrm{C}-\mathrm{O}$ dihedral angle is $14.5^{\circ}$ and $24.1^{\circ}$, while in polar solvents the dihedral angle is wider $\left(78.8^{\circ}\right.$ and $78.1^{\circ}$ for water and acetonitrile, respectively), which results from a rotation of the lactone head group which stabilises the structure. One possible explanation for this is that the dipole of each N-H and $\mathrm{C}=\mathrm{O}$ might favour the parallel alignment in the gas phase and in non-polar solvents (chloroform) while the polar solvents (acetonitrile and water) largely destabilise the "dipole-dipole" interaction. However, there is no evidence for any dipole-dipole interactions being present. This lactone head group rotation, upon solvation in polar solvents, has been found in all of the structures shown in Figure 10, except $\mathbf{B}, \mathbf{F}$ and $\mathbf{J}$. It is also worth noting that any attempt to obtain enol $\mathbf{E}$ shows it to revert to enol $\mathbf{D}$ at any computational level, both in the gas phase or using a solvent model. 
<smiles>CCC(=O)[CH]C(=O)N[C@H]1CCOC1=O</smiles><smiles>CCC(=O)NC12OCC[C@H]1NC(=O)[C-][O+]=C2CC</smiles>

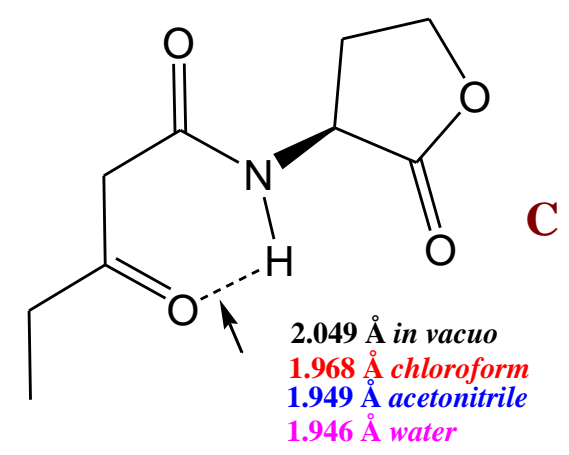<smiles></smiles><smiles>CCC1=[O+][CH]OC(N[C@@H]2CCOC2=O)=C1</smiles>

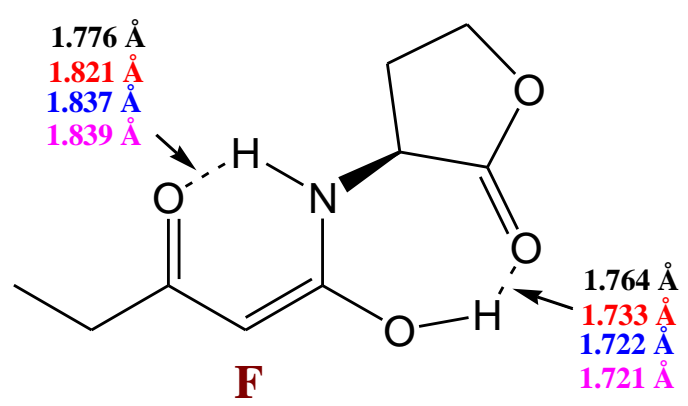

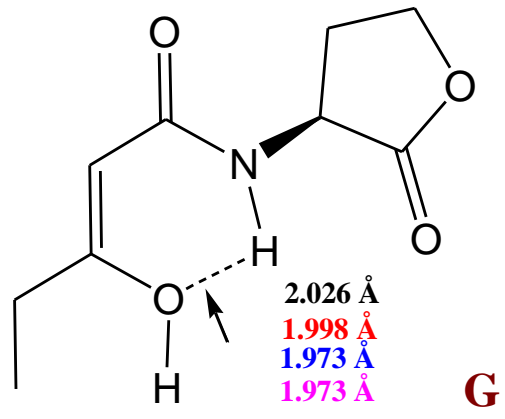

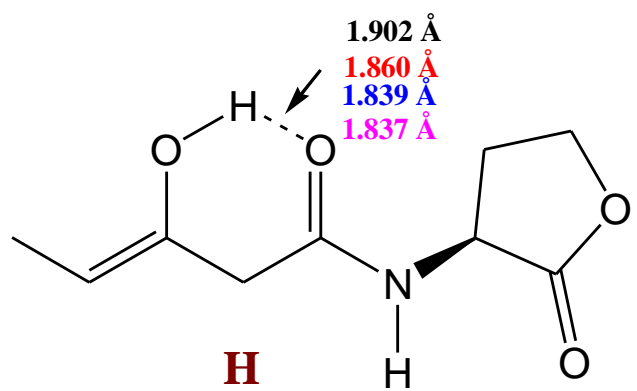

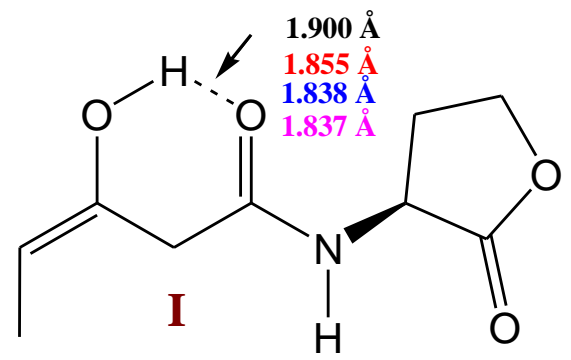

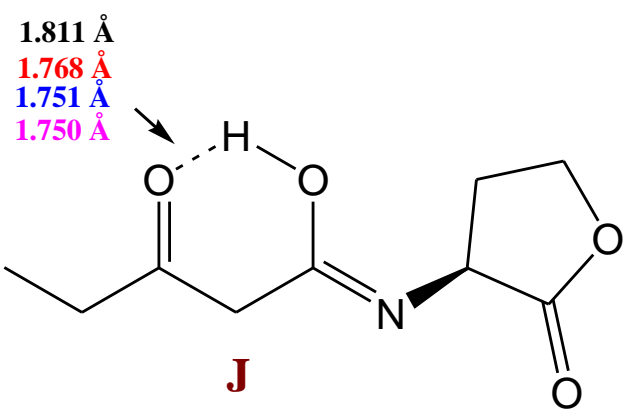

Figure 10. Keto and enol tautomers of OHLs, with HB distances shown 
Interestingly the overall lowest energy conformer obtained in vacuo (Figure 11) was the enol conformer $\mathbf{D}$, being more stable than the keto conformer $\mathbf{C}$, by $1.53 \mathrm{kcal} / \mathrm{mol}$ (Table 3).
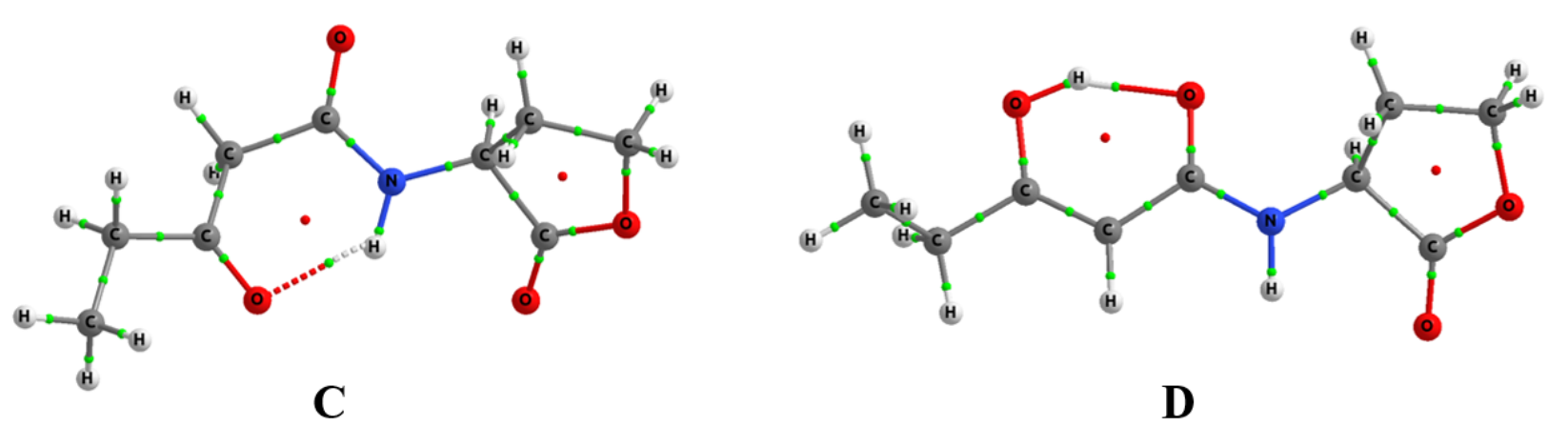

Figure 11. (a) Molecular graph corresponding to the $\mathbf{C}$ and $\mathbf{D}$ conformers at the B3LYP/6-311++G(d,p) computational level. Green and red dot corresponds to the $\mathrm{BCP}$ and ring critical points, respectively.

Table 3. Relative energies (in $\mathrm{kcal} / \mathrm{mol}$ ), at the B3LYP/6-311++G(d,p) computational level, for the conformers A-J in the gas phase, chloroform, acetonitrile and water solvent models, including zero-point correction.

\begin{tabular}{cllll}
\hline Conformer & Gas Phase & Chloroform & Acetonitrile & Water \\
\hline A & 3.81 & 2.26 & 1.70 & 1.60 \\
B & 3.18 & 1.63 & 1.09 & 1.77 \\
$\mathbf{C}$ & 1.53 & $\mathbf{0 . 0 0}$ & $\mathbf{0 . 0 0}$ & $\mathbf{0 . 0 0}$ \\
$\mathbf{D}$ & $\mathbf{0 . 0 0}$ & 0.78 & 1.35 & 1.41 \\
$\mathbf{F}$ & 11.40 & 11.44 & 12.27 & 12.34 \\
$\mathbf{G}$ & 11.02 & 9.20 & 8.79 & 8.77 \\
$\mathbf{H}$ & 11.04 & 10.68 & 11.03 & 10.98 \\
I & 13.34 & 12.54 & 12.75 & 12.71 \\
J & 15.42 & 14.20 & 14.43 & 14.44
\end{tabular}

However, solvent calculations show that the keto conformer $\mathbf{C}$ is marginally more stable than conformer $\mathbf{D}$ in solution, and that the difference is more appreciable in polar than non-polar solvents, at up to $1.41 \mathrm{kcal} / \mathrm{mol}$ (Table 3). This is in agreement with the solution NMR results which show that the keto form is predominant in $\mathrm{CDCl}_{3}$ and $\mathrm{CD}_{3} \mathrm{CN}$. This energy difference is small when compared to all of the other 
enol tautomers examined which showed significantly higher energy differences ( 11.4-15.42 kcal/mol, Table 3).

Regarding possible stabilising $\mathrm{n} \rightarrow \pi^{*}$ interactions in the enol structures studied, AIM results in all the cases (Figure S1 in Supporting Information) do not show the presence of a BCP between the corresponding atoms. Furthermore, NBO calculations do not show any evidence for the existence of the $n \rightarrow \pi^{*}$ interactions in these particular conformers. As observed in Table S1, the main intramolecular charge transfer occurs due to the existence of an intramolecular $\mathrm{HB}$ with $\mathrm{E}(2)$ values ranging from 3.7 to $25.7 \mathrm{kcal} / \mathrm{mol}$ for the gas phase. When the solvent is taken into account (acetonitrile) there is a slight enhancement of the NBO charge transfer, as expected for polar solvents. As observed the second order interaction energy values increase, with up to $4.2 \mathrm{kcal} / \mathrm{mol}$ for enol $\mathbf{J}$. This is in agreement with the AIM results which show the presence of a BCP in the HBs, with electron density values ranging from 0.0115 to 0.0515 a.u. Furthermore, the negative value of the total electron energy density at $\mathrm{BCP}, \mathrm{H}_{\mathrm{BCP}}$, confirms the covalent character of the corresponding interaction. The correlation between the negative $\mathrm{H}_{\mathrm{BCP}}$ values and the covalent character in $\mathrm{HBs}$ was already studied; it was found that those $\mathrm{HB}$ with negative $\mathrm{H}_{\mathrm{BCP}}$ values were classified as the strong interactions possessing some covalent character. $^{29,30}$ Similar negative values was also found in compound $\mathbf{D}, \mathbf{F}$ and $\mathbf{J}$, which classified those HBs as strong interactions. ${ }^{18}$

\subsection{Conformers of lactone head replacements for OHLs}

A number of lactone head replacements have also shown significant bioactivity. ${ }^{4 a, b}$ These include the phenyl, cyclopentyl and thiolactone substituted molecules ( $\mathbf{K}, \mathbf{M}$ and $\mathbf{O})$ shown in Figure 12. 

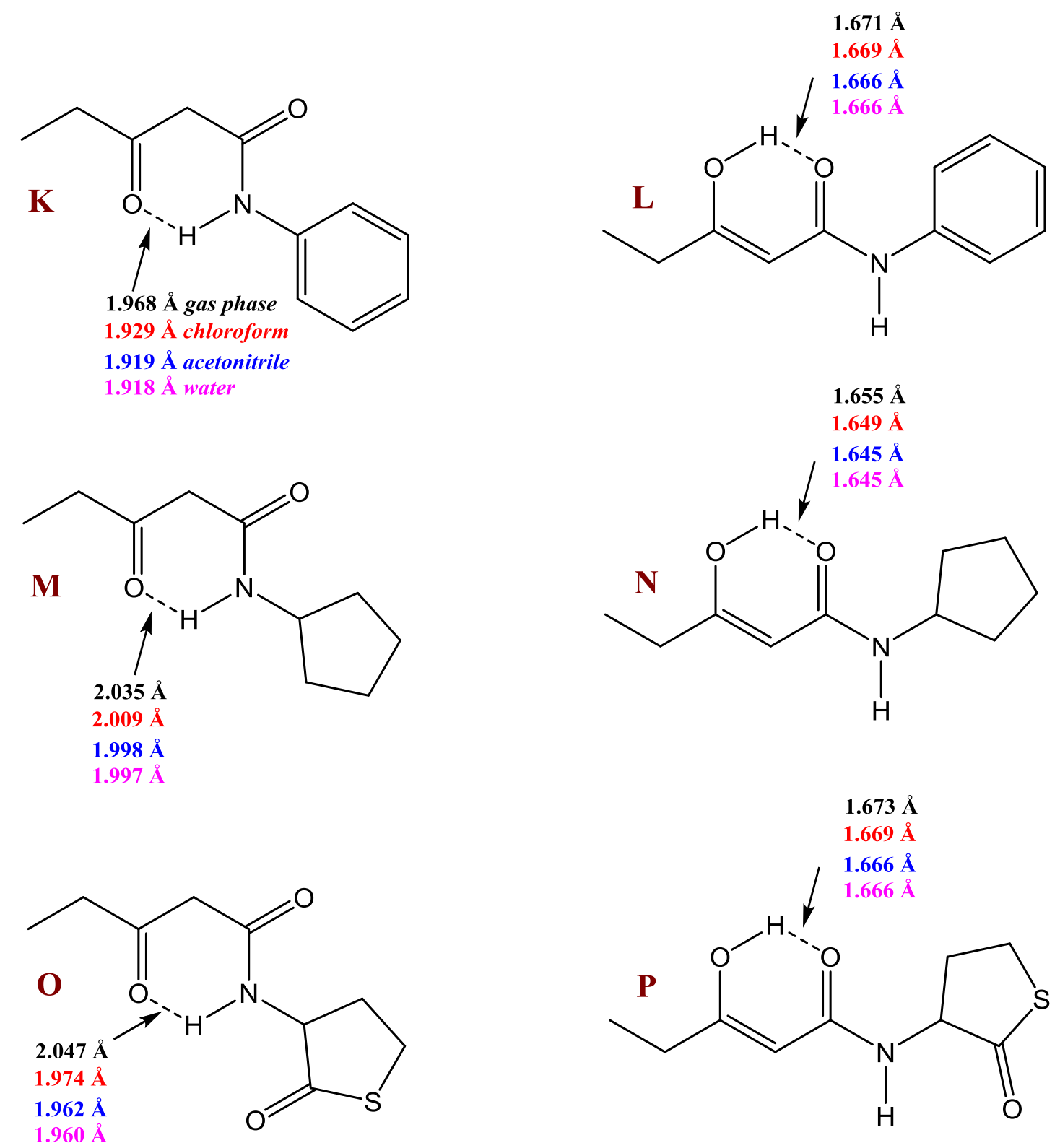

Figure 12. Observed conformers of OHLs with lactone head group replacements, with HB distances shown.

When DFT calculations were undertaken to find the relative energies of their keto and enol tautomers, similar results to those of the parent OHLs were found, although with some slight differences in their relative minimised energy differences (0.03-1.54 $\mathrm{kcal} / \mathrm{mol}$ ) (Table 4). 
Table 4. Relative energies (in $\mathrm{kcal} / \mathrm{mol}$ ) at the B3LYP/6-311++G(d,p) computational level for the K-P structures in gas phase, chloroform, acetonitrile and water solvent models, including zero-point correction

\begin{tabular}{ccccc}
\hline Conformer & Gas Phase & Chloroform & Acetonitrile & Water \\
\hline $\mathbf{K}$ & 0.00 & 0.00 & 0.00 & 0.00 \\
$\mathbf{L}$ & 0.03 & 1.21 & 1.51 & 1.54 \\
$\mathbf{M}$ & 0.41 & 0.00 & 0.00 & 0.00 \\
$\mathbf{N}$ & 0.00 & 0.85 & 1.23 & 1.26 \\
$\mathbf{O}$ & 1.54 & 0.00 & 0.00 & 0.00 \\
$\mathbf{P}$ & 0.00 & 0.87 & 1.31 & 1.33
\end{tabular}

In the case of $\mathbf{K}$ and $\mathbf{L}$, both tautomers show an intramolecular $\mathrm{HB}$, with keto $\mathbf{K}$ being marginally more stable than enol $\mathbf{L}$ in the gas phase. This difference is more appreciable when the solvent effects are taken into account. In the case of $\mathbf{M - N}$ and O-P the enol forms are more stable than the keto forms in the gas phase. However, in solution the stability is reversed. In order to give an insight on the strength of the intramolecular bonds, AIM and NBO analysis have been carried out (Table S2 in Supporting Information). For consistency, only HBs which involve similar type of atoms can be compared. In the case of keto tautomers $\mathbf{K}, \mathbf{M}$ and $\mathbf{O}$, despite the three HBs being relatively close in terms of stability, the observed trend in the gas phase in the $\mathrm{H} \cdots \mathrm{O}$ distances $(\mathrm{K}<\mathrm{M}<\mathrm{O})$ and $\rho_{\mathrm{BCP}}(\mathrm{K}>\mathrm{M}>\mathrm{O})$ suggests that $\mathbf{K}$ presents the strongest HB. This is corroborated by the NBO E(2) values for the donation from the $\mathrm{O}_{\mathrm{lp}}$ into the $\mathrm{N}-\mathrm{H} \sigma^{*}$ antibonding orbital, $\mathbf{K}(7.1 \mathrm{kcal} / \mathrm{mol})>\mathbf{M}(5.1 \mathrm{kcal} / \mathrm{mol})>\mathbf{O}(4.9$ $\mathrm{kcal} / \mathrm{mol}$ ). Similar trends were found in acetonitrile as solvent, with slightly larger $\mathrm{E}(2)$ values and shorter distances, evidencing an enhancement of the intramolecular HBs in polar solvents.

In the case of enol tautomers $\mathbf{L}, \mathbf{N}$ and $\mathbf{P}$, the shortest observed $\mathrm{H} \cdots \mathrm{O}$ distance for $\mathbf{N}$, in conjunction with the largest $\rho_{\mathrm{BCP}}$ and $\mathrm{E}(2)$ values indicate that tautomer $\mathbf{N}$ presents the strongest intramolecular HB. Additionally, the most negative $\mathrm{H}_{\mathrm{BCP}}$ values found in $\mathbf{N}$ corroborates the larger covalent character of that particular HB. As occurred with the keto tautomers $\mathbf{K}, \mathbf{M}$ and $\mathbf{O}$, enol tautomers $\mathbf{L}, \mathbf{N}$ and $\mathbf{P}$ show an enhancement of the HB strengths in polar solvents (acetonitrile) due to an increase of the second order 
orbital interaction energies, electron density values at the BCPs, in conjunction with a shortening of the $\mathrm{H} \cdots \mathrm{O}$ distances.

As seen for the OHLs there was no evidence for any extended keto tautomer, with compact H-bonded conformers, analogous to $\mathbf{C}$, being observed in every case. Furthermore, due to the conformational arrangement, there is no evidence for any minimised energy conformations involving stabilising $n \rightarrow \pi *$ interactions.

It is noteworthy that the published ${ }^{1} \mathrm{H}$ NMR chemical shifts in $\mathrm{CDCl}_{3}$ for the $\mathrm{N}-\mathrm{H}$ proton for the phenyl, cyclopentyl and thiolactone compounds are 9.15 ppm, 6.99 ppm and $7.55 \mathrm{ppm}$, respectively, and are shown in Figure 13, along with other structures of relevance to this study. ${ }^{4}$ The value for the $N$-phenyl derivative is high because of the electron-withdrawing effect of the phenyl group. In general, the $\mathrm{N}$ alkyl substituents show an upfield movement in chemical shift due to the electrondonating alkyl groups, while the other OHL analogues, containing $\beta$-amide, ester and sulfoxide groups, show chemical shifts in the same region as those observed for the natural OHLs used in this study. 
<smiles>CCCCC(=O)CC(=O)Nc1ccccc1</smiles>

$9.15 \mathrm{ppm}$<smiles>CCCCCC(=O)CC(=O)N[C@H]1CCSC1=O</smiles>

$7.40 \mathrm{ppm}$<smiles>CCCCCC(=O)CC(=O)N[C@@H](C)C(=O)OC</smiles>

7.46 ppm<smiles>CCCC(=O)CC(=O)N[C@H]1CCCCC1=O</smiles>

$7.53 \mathrm{ppm}$<smiles>CCOC(=O)CC(=O)N[C@H]1CCOC1=O</smiles>

$7.80 \mathrm{ppm}$<smiles>CCCCC(=O)CC(=O)NC1CCCC1</smiles>

$6.99 \mathrm{ppm}$<smiles>CCCCC(C)=O</smiles>

6.87 ppm<smiles>CCCCC(C)C(=O)CC(=O)N[C@@H]1CCCC1=O</smiles>

$7.40 \mathrm{ppm}$<smiles>CCNC(=O)CC(=O)N[C@@H]1CCOC1=O</smiles>

$7.80 \mathrm{ppm}$<smiles>CCC[S+]([O-])CC(=O)N[C@H]1CCOC1=O</smiles>

$7.80 \mathrm{ppm}$

Figure 13. ${ }^{1} \mathrm{H}$ NMR chemical shift data for the amide N-H proton, for a range of head-group and side-chain OHL analogues

\subsection{Conformational flexibility of OHLs}

The conformational preferences of the keto forms of OHLs observed in vacuo, in solution (NMR and computational), in the solid-state and receptor-bound are different, which along with the possibility of enol tautomer conformations shows that the molecules have a significant level of flexibility. In order to examine this flexibility 
we measured a series of dihedral angles for the observed conformations of the keto and enol tautomers (Figure 14).<smiles>CCC(=O)CC(=O)N[C@H]1CCOC1=O</smiles>

A

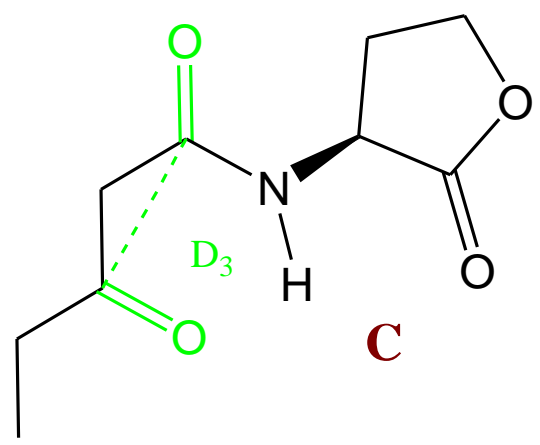

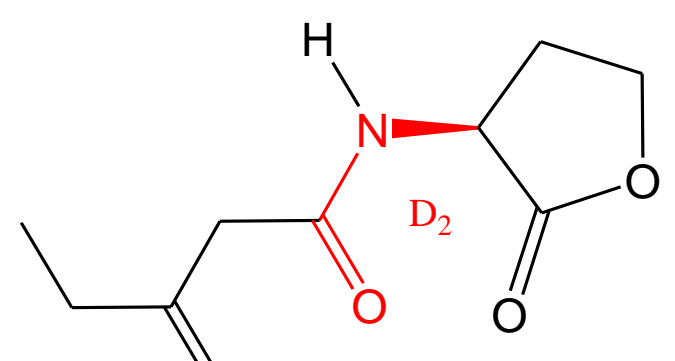

B

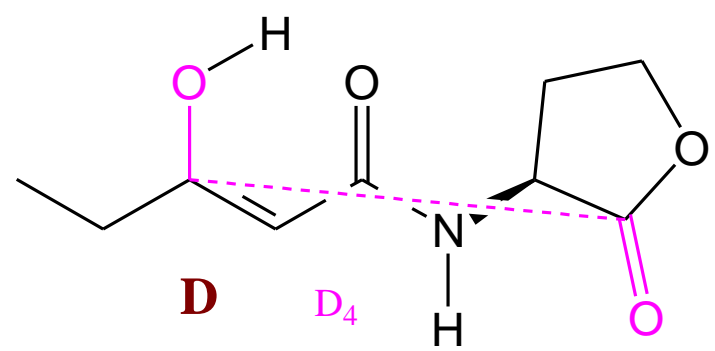

Figure 14. Graphical representation of the dihedral angles $D_{1}-D_{4}$ for OHL conformations A-D

For the conformers A-D the dihedral angles are defined as: a) $D_{1}$ shows the alignment of the $\mathrm{N}-\mathrm{H}$ and the lactone $\mathrm{C}=\mathrm{O}$ group which shows how the side chain is aligned relative to the lactone ring ; b) $\mathrm{D}_{2}$ is the amide linker dihedral and would be expected to be close to $0^{\circ}$; c) $D_{3}$ is the dihedral formed by the two carbonyl groups in the side chain which shows the overall extension (linearity) of the side chain ; and d) $\mathrm{D}_{4}$ is dihedral between the keto or enol $\mathrm{C}-\mathrm{O}$ and the lactone carbonyl, which shows the overall planarity of the side chain relative to the lactone head group. Table 5 shows these measured dihedral angle values for the important OHL conformations A-D.

\begin{tabular}{|c|c|c|c|c|}
\hline Conformer A & $\mathbf{D}_{\mathbf{1}}$ & $\mathbf{D}_{\mathbf{2}}$ & $\mathbf{D}_{\mathbf{3}}$ & $\mathbf{D}_{\mathbf{4}}$ \\
\hline Gas phase & 17.6 & 5.6 & 79.0 & 110.9 \\
\hline Chloroform & 33.0 & 3.1 & 60.1 & 151.7 \\
\hline Acetonitrile & 79.4 & 1.5 & 53.2 & 140.3 \\
\hline Water & 80.6 & 1.7 & 50.6 & 134.9 \\
\hline Conformer B & & & & \\
\hline
\end{tabular}




\begin{tabular}{|c|c|c|c|c|}
\hline Gas phase & 65.7 & 5.5 & 164.1 & 99.3 \\
\hline Chloroform & 72.0 & 0.9 & 164.0 & 101.8 \\
\hline Acetonitrile & 73.6 & 1.1 & 81.2 & 179.8 \\
\hline Water & 73.8 & 1.2 & 79.6 & 178.3 \\
\hline Conformer C & & & & \\
\hline Gas phase & 38.9 & 2.7 & 160.3 & 52.3 \\
\hline Chloroform & 70.8 & 0.3 & 160.7 & 89.9 \\
\hline Acetonitrile & 77.9 & 1.0 & 164.8 & 96.0 \\
\hline Water & 78.3 & 1.1 & 165.3 & 96.1 \\
\hline Conformer D & & & & \\
\hline Gas phase & 14.5 & 9.4 & 0.1 & 153.7 \\
\hline Chloroform & 24.1 & 7.4 & 0.3 & 147.4 \\
\hline Acetonitrile & 78.1 & 0.3 & 0.0 & 97.8 \\
\hline Water & 78.8 & 0.0 & 0.0 & 97.2 \\
\hline
\end{tabular}

Table 5. Measured values of dihedral angles $\mathrm{D}_{1}-\mathrm{D}_{4}$, from DFT calculations of OHL keto and enol conformations A-D

As expected, the dihedral $D_{2}$ is close to zero for all conformations in the gas phase and solvent models. The $\mathrm{D}_{1}$ dihedral angle, for conformations $\mathbf{A}, \mathbf{C}$ and $\mathbf{D}$ shows a marked solvent dependence when compared to the value in the gas phase. As the solvent polarity increases then the alignment of the $\mathrm{N}-\mathrm{H}$ and $\mathrm{C}=\mathrm{O}$ moves from almost parallel in the gas phase to almost perpendicular in water, thus demonstrating a significant level of flexibility. The relative alignment of the two side chain carbonyl groups, as measured by the $\mathrm{D}_{3}$ dihedral, shows significant differences for all four conformations. For conformation A, the two carbonyl groups are offset by $50^{\circ}$ to $79^{\circ}$ most probably due to the electronic repulsion of the two groups. For conformation $\mathbf{B}$, in the gas phase and in non-polar chloroform the two carbonyls are aligned in an almost anti-parallel arrangement $\left(\mathrm{D}_{3}=164^{\circ}\right)$, while in the polar solvents the groups are close to perpendicular. Not surprisingly, for conformation $\mathbf{C}, \mathrm{D}_{3}$ is similar in all cases as this conformation is stabilised by presence of the intramolecular HB. Again it was observed, as expected, that the enol $\mathrm{C}-\mathrm{O}$ and amide $\mathrm{C}=\mathrm{O}$ would be aligned in a syn-parallel arrangement due to the planarity of the six-membered ring of the intramolecularly H-bonded enol tautomer. Finally dihedral $\mathrm{D}_{4}$ in conformer $\mathbf{B}$ is close to a right angle for the gas phase and in chloroform but is anti-parallel in polar solvents, as is evident in figure $7 \mathbf{a}$ and $\mathbf{b}$. Further evidence for the strength of the 
intramolecular $\mathrm{HB}$ in solution in conformer $\mathbf{C}$ comes from the fact that $\mathrm{D}_{4}$ is a right angle in all three solvent models.

\subsection{Conclusions}

Blackwell reported that the order of importance of the HBs when binding to the LasR receptor is amide $\mathrm{N}-\mathrm{H}>3$-keto $\mathrm{C}=\mathrm{O}>$ lactone $\mathrm{C}=\mathrm{O}>$ amide $\mathrm{C}=\mathrm{O} .{ }^{5}$ Therefore, when the extended keto conformer A (see Figure 2) of OHLs binds to the LasR receptor the loss of the one stabilising intramolecular HB present in $\mathbf{C}$ is more than compensated by the new individual HBs between the amino acid residues of the receptor binding pocket and the HB donor/acceptor groups of the OHLs. However, the computational studies reported here can not preclude the possibility that the enol tautomer $\mathbf{D}$, or a closely related enol structure H-bonded to the receptor, is a bioactive conformation of 3-oxo AHLs in vivo. However, it is an extended keto tautomer which is present when the receptor-ligand complex crystallises. ${ }^{8}$

In conclusion, DFT calculations have shown that a compact $\mathrm{H}$-bonded structure $(\mathbf{C})$ is the lowest energy keto conformation for OHLs in the gas phase, as well as in solvent models. In the gas phase the keto $(\mathbf{C})$ and enol (D) tautomers are of equal energy but the keto tautomer is more stable in solution. ${ }^{1} \mathrm{H}$ NMR studies in dilute solutions (1 $\mathrm{mM}$ in $\mathrm{CDCl}_{3}$ and $\mathrm{CD}_{3} \mathrm{CN}$ ) of a range of natural OHLs show that the enol tautomer is the minor tautomer (4-7\%). The NMR studies show that the chemical shift of the amide N-H proton is significantly further downfield in the OHLs when compared to the AHLs, which lack the 3-oxo group. The chemical shift of the amide N-H is also independent of concentration confirming that the $\mathrm{HB}$ is intramolecular. An examination of key dihedral angles for conformations A-D shows the flexibility of the OHL molecules but especially demonstrates how the conformational preferences are highly solvent dependent. Finally, and most importantly, these detailed computational and NMR studies again reiterate the fact that care must be taken in reaching conclusions on exact ligand (or protein) bioactive conformations based solely on calculations in vacuo or one solvent model, x-ray crystal structures including ligandbound receptor structures, or indeed solution NMR data, as in reality the actual picture is likely to be far more complicated. ${ }^{31}$ 


\subsection{Materials and methods}

The $\mathrm{C}_{6}-\mathrm{C}_{14}$ OHLs were purchased from Sigma-Aldrich (Irl) Ltd. NMR spectra were obtained on a Bruker Avance III 300 spectrometer operating at $300 \mathrm{MHz}$ for ${ }^{1} \mathrm{H}$ spectra or Bruker Avance III 500 spectrometer operating at $500 \mathrm{MHz}$. Compounds were dissolved to a final concentration of $1 \mathrm{mM}$ in $\mathrm{CDCl}_{3}$ or $\mathrm{CD}_{3} \mathrm{CN}$ and allowed to equilibrate for seven days.

Geometry optimisations were carried out at the B3LYP/6-311++G(d,p) level of theory as implemented. Harmonic vibrational frequencies were computed at the same level used for the geometry optimisations in order to classify the stationary points either as local minima or transition states (TS). Calculations were performed using the Gaussian09 programme. $^{32}$

The Natural Bond Orbital (NBO) method ${ }^{15}$ was employed to analyse chargetransfer interactions between occupied and unoccupied orbitals using the NBO-3 programme. The Atoms in Molecules (AIM) methodology ${ }^{16}$ was used to analyze the electron density of the systems with the AIMAll program. ${ }^{33}$ The NCI (non-covalent interactions) index, ${ }^{19}$ based on the reduced gradient of the electron density, has been calculated to identify attractive and repulsive interactions with the NCI program and plotted with the VMD programme. ${ }^{34}$ The energy minimized structure in the graphical abstract was produced using the PyMol 1.3 graphics system. ${ }^{35}$

\section{Acknowledgements}

We are grateful to the Higher Education Authority's Programme for Research in Third-Level Institutions (Cycle IV) for funding for AN, and to the Irish Research Council and VEC Dublin for funding for DC. Thanks are given to the Irish Centre for High-End Computing (ICHEC) for the provision of computational facilities.

\section{Supplementary data}

${ }^{1} \mathrm{H}$ NMR spectra for OHLs in $\mathrm{CDCl}_{3}$ and $\mathrm{CD}_{3} \mathrm{CN}$; Cartesian co-ordinates for minimised energy conformations of the keto and enol tautomers for conformers A-P in the gas phase, chloroform, acetonitrile and water; and molecular graphs for conformers A-P are included. 


\section{References and Notes}

1. World Health Organisation (2014) Antimicrobial Resistance: Global report on surveillance.

http://www.who.int/drugresistance/documents/surveillancereport/en/, accessed on January $23^{\text {rd }} 2017$.

2. Kalia, V. C. Biotechnol. Adv. 2013, 31, 224.

3. Schuster, M.; Sexton, D. J.; Diggle, S. P.; Greenberg, E. P. Annu. Rev. Microbiol. 2013, 67, 43.

4. A non-exhaustive list includes (a) Welsh, M. A.; Blackwell, H. E. FEMS Microbiol. Rev. 2016, 40, 774. (b) Moore, J. D.; Rossi, F. M.; Welsh, M. A.; Nyffler, K. E.; Blackwell, H. E. J. Am. Chem. Soc. 2015, 137, 14626. (c) Guo, M.; Zheng, Y.; Starks, R.; Opoku-Temeng, C.; Ma, X.; Sintim, H. O. Med. Chem. Commun. 2015, 6, 1086. (d) McInnis, C.; Blackwell, H. E. ChemBioChem 2014, 15, 87. (e) Syrpas, M.; Ruysbergh, E.; Stevens, C. V.; De Kimpe, N.; Mangelinckx, S. Beilstein J. Org. Chem. 2014, 10, 2539. (f) Stacy, D. M.; Le Quement, S. T.; Hansen, C. L.; Clausen, J. W.; Tolker-Nielsen, T.; Brummond, J. W.; Givskov, M.; Nielsen, T. E.; Blackwell, H. E. Org. Biomol. Chem. 2013, 11, 938. (g) Zhao, M.; Yu, Y.; Hua, Y.; Feng, F.; Tong, Y.; Yang, X.; Xiao, J.; Song, H. Molecules 2013, 18, 3266. (h) Stacy, D. M.; Welsh, M. A.; Rather, P. N.; Blackwell, H. E. ACS Chem. Biol. 2012, 7, 1719. (i) Sabbah, M.; Fontaine, F.; Grand, L.; Boukraa, M.; Efrit, M. L.; Doutheau, A.; Soulère, L.; Queneau, Y. Bioorg. Med. Chem. Lett. 2012, 20, 4727. (j) McInnis, C.; Blackwell, H. E. Bioorg. Med. Chem. 2011, 19, 4820. (k) Marsden, D. M.; Nicholson, R. L.; Skindersoe, M. E.; Galloway, W. R.; Sore, H. F.; Givskov, M.; Salmond, G. P.; Ladlow, M.; Welch, M.; Spring, D. R. Org. Biomol. Chem. 2010, 8, 5313. (1) Thiel, V.; Kunze, B.; Verma, P.; Wagner-Döbler, I.; Schulz, S. ChemBioChem 2009, 10, 1861. (m) Frezza, M.; Soulère, L.; Reverchon, S.; Guiliani, N.; Jerez, C.; Queneau, Y.; Doutheau, A. Bioorg. Med. Chem. 2008, 16, 3550. (n) Geske, G. D.; Mattman, M. E.; Blackwell, H. E. Bioorg. Med. Chem. Lett. 2008, 18, 5978.

5. Gerdt, J. P.; McInnis, C. E.; Schell, T. L.; Blackwell, H. E. Org. Biomol. Chem. 2015, 13, 1453.

6. Newberry, R. W.; Raines, R. T. ACS Chem. Biol. 2014, 9, 880. 
7. Tumminakatti, S.; Khatri, B.; Krishnamurti, V.; Athavale, V.; Prabhakaran, E. N. Tetrahedron Lett. 2015, 56, 5771.

8. Newberry, R. W.; Raines, R. T. Acta Cryst. 2016, E72, 136

9. www.rcsb.org, Berman H. M.; Westbrook, J.; Feng, Z.; Gilliland, G.; Bhat, T. N.; Weissig, H.; Shindyalov, I. N.; Bourne, P. E. Nucleic Acids Res. 2000, 28, 235, accessed on January $23^{\text {rd }} 2017$.

10. Kržan, M.; Vianello, R.; Maršavelski, A.; Repič, M.; Zakšek, M.; Kotnik, K.; Fijan., Mavri, J. PLoS ONE, 2016, 11, e0154002.

11. Liao, R.; Georgieva, P.; Yu, J.; Himo, F. Biochemistry, 2011, 50, 1505.

12. a) Geske, G. D.; O’Neill, J. C.; Miller, D. M.; Mattman, M. E.; Blackwell, H. E. J. Am. Chem. Soc. 2003, 129, 13613. b) Chhabra, S. R.; Harty, C.; Hooi, D. S.; Daykin, M.; Williams, P.; Telford, G.; Pritchard, D. I.; Bycroft, B. W. J. Med. Chem. 2003, 46, 97.

13. Formaggio, F.; Crisma, M.; Ballano, G. Peggion, C.; Venanzi, M.; Toniolo, C. Org. Biomol. Chem. 2012, 10, 2413.

14. Newberry, R. W.; Raines, R. T. Nat. Chem. Biol. 2016, 12, 1084.

15. Reed, A. E.; Curtiss, L. A.; Weinhold, F. Chem. Rev. 1988, 88, 899.

16. a) Bader, R. F. Atoms in Molecules: A Quantum Theory. Clarendon Press: Oxford, 1990; b) Popelier, P. L., Atoms In Molecules. An Introduction. Prentice Hall: Harlow, England, 2000.

17. a) Cremer, D.; Kraka, E., Croat. Chem. Acta 1984, 57, 1259. b) Jenkins, S.; Morrison, I., Chem. Phys. Lett. 2000, 317, 97. c) Arnold, W. D.; Oldfield, E., J. Am. Chem. Soc. 2000, 122, 12835.

18. An Introduction to Hydrogen Bonding, G. A. Jeffrey, Oxford University Press, 1997.

19. Johnson, E. R.; Keinan, S.; Mori-Sánchez, P.; Contreras-García, J.; Cohen, A. J.; Yang, W. J. Am. Chem. Soc. 2010, 132, 6498.

20. Azofra, L. M.; Scheiner, S. J. Chem. Phys. 2015, 142, 34307.

21. Altarsha, M.; Ingrosso, F.; Ruiz-Lopez, M. F. ChemPhysChem 2012, 13, 3397. 
22. San-Fabián, E.; Ingrosso, F.; Lambert, A.; Bernal-Uruchurtu, M. I.; RuizLopez, M. F. Chem. Phys. Lett. 2014, 601, 98.

23. Bartlett, G. J.; Choudhary, A.; Raines, R. T.; Woolfson, D. N. Nat. Chem. Biol. 2010, 6, 615 .

24. Newberry, R. W.; Orke, S. J.; Raines, R. T. Org. Lett. 2016, 18, 3614.

25. a) Lintz, M. J.; Oinuma, K. -I.; Wysoczynski, C. L.; Greenberg, E. P.; Churchill, M. E. Proc. Nat. Acad. Sci. 2011, 108, 15673. b) Churchill, M. E.; Chen, L. Chem. Rev. 2011, 111, 68. c) Zou, Y.; Nair, S. K. Chem. Biol. 2009, 16, 961. d) Bottomley, M. J.; Muraglia, E.; Bazzo, R.; Carfi, A. J. Biol. Chem. 2007, 282, 13592. e) Debler, E. W.; Kaufmann, G. F.; Kirchdoerfer, R. N.; Mee, J. M.; Janda, K. D.; Wilson, I. A. L. Mol. Biol. 2007, 368, 1392. f) Vannini, A.; Volpari, C.; Gargioli, C.; Muraglia, E.; Cortese, R.; De Francesco, R.; Neddermann, P.; Di Marco, S. EMBO J. 2002, 21, 4393. g) Zhang, R. -G.; Pappas, T.; Brace, J. L.; Miller, P. C.; Oulmassov, T.; Molyneaux, J. M.; Anderson, J. C.; Bashkin, J. K.; Wians, S. C.; Joachimiak, A. Nature 2002, 417, 971.

26. a) Smith, K. T.; Young, S. C.; DeBlasio, J. W.; Hamann, C. S. J. Chem. Educ. 2016, 93, 790. b) Claramunt, R. M.; López, C.; Santa María, M. D.; Sanz, D.; Elguero, J. Prog. Nucl. Magn. Reson. Spectrosc. 2006, 49, 169.

27. a) Laurella, S. L.; Gonzalez Sierra, M.; Furlong, J. J.; Allegretti, P. E. Open J. Phys. Chem. 2013, 3, 138. b) Laurella, S.; Gonzalez Sierra, M.; Furlong, J.; Allegretti, P. J. Appl. Sol. Chem. Model. 2012, 1, 6. c) Sung, K.; Wu, R. -R, Sun, S. -Yi. J. Phys. Org. Chem. 2002, 15, 775. d) Bunting, J. W.; Kanter, J. P. J. Am. Chem. Soc. 1993, 115, 11705.

28. Kline, T.; Bowman, J.; Iglewski, B. H.; de Kievit, T.; Kakai, Y.; Passador, L. Bioorg. Med. Chem. Lett. 1999, 9, 3447.

29. Alkorta, I.; Sánchez-Sanz, G.; Elguero, J.; Del Bene, J. E. J. Phys. Chem. A 2014, 118, 1527.

30. Grabowski, S. J. Chem. Rev. 2011, 111, 2597.

31. a) Kuhnert, M.; Diederich, W. Synlett 2016, 27, 641. b) Deller, M. C.; Rupp, B. J. Comput. Aided Mol. Des. 2015, 29, 817. c) Davis, A. M.; StGallay, S. A.; Kleywegt, G. J. Drug Discov. Today 2008, 13, 831. 
32. Frisch, M. J.; Trucks, G. W.; Schlegel, H. B.; Scuseria, G. E.; Robb, M.

A.; Cheeseman, J. R.; Scalmani, G.; Barone, V.; Mennucci, B.; Petersson,

G. A.; Nakatsuji, H.; Caricato, M.; Li, X.; Hratchian, H. P.; Izmaylov, A.

F.; Bloino, J.; Zheng, G.; Sonnenberg, J. L.; Hada, M.; Ehara, M.; Toyota,

K.; Fukuda, R.; Hasegawa, J.; Ishida, M.; Nakajima, T.; Honda, Y.; Kitao,

O.; Nakai, H.; Vreven, T.; Montgomery, J., J. A.; Peralta, J. E.; Ogliaro,

F.; Bearpark, M.; Heyd, J. J.; Brothers, E.; Kudin, K. N.; Staroverov, V.

N.; Kobayashi, R.; Normand, J.; Raghavachari, K.; Rendell, A.; Burant, J.

C.; Iyengar, S. S.; Tomasi, J.; Cossi, M.; Rega, N.; Millam, N. J.; Klene,

M.; Knox, J. E.; Cross, J. B.; Bakken, V.; Adamo, C.; Jaramillo, J.;

Gomperts, R.; Stratmann, R. E.; Yazyev, O.; Austin, A. J.; Cammi, R.;

Pomelli, C.; Ochterski, J. W.; Martin, R. L.; Morokuma, K.; Zakrzewski, V. G.; Voth, G. A.; Salvador, P.; Dannenberg, J. J.; Dapprich, S.; Daniels, A. D.; Farkas, Ö.; Foresman, J. B.; Ortiz, J. V.; Cioslowski, J.; Fox, D. J. Gaussian 09, Revision d1, Inc.: Wallingford CT, 2009.

33. Keith, T. A. AIMAll, TK Gristmill Software Version 15.09.27; 2015.

34. Humphrey, W.; Dalke, A.; Schulten, K. J. Mol. Graph. 1996, 14, 33.

35. The PyMOL Molecular Graphics System, Version 1.3 Schrödinger, LLC.

Supporting Information 


\section{Conformational studies of Gram-negative bacterial quorum sensing 3-oxo $N$-acyl}

homoserine lactone molecules

Darren Crowe, ${ }^{\mathrm{a}}$ Alan Nicholson, ${ }^{\mathrm{a}}$ Adrienne Fleming, ${ }^{\mathrm{a}}$ Ed Carey, ${ }^{\mathrm{a}}$ Goar Sánchez-Sanz ${ }^{\mathrm{b}}$ and Fintan Kelleher ${ }^{\text {a* }}$

${ }^{a}$ Molecular Design and Synthesis Group, Centre of Applied Science for Health, Institute of Technology Tallaght, Dublin 24, Ireland.

${ }^{\mathrm{b}}$ Irish Centre of High-End Computing, Grand Canal Quay, Dublin 2, Ireland

\section{Materials and methods}

The $\mathrm{C}_{6}-\mathrm{C}_{14}$ OHLs were purchased from Sigma-Aldrich (Irl) Ltd. NMR spectra were obtained on a Bruker Avance III 300 spectrometer operating at $300 \mathrm{MHz}$ for ${ }^{1} \mathrm{H}$ spectra or Bruker Avance III 500 spectrometer operating at $500 \mathrm{MHz}$. Compounds were dissolved to a final concentration of $1 \mathrm{mM}$ in $\mathrm{CDCl}_{3}$ or $\mathrm{CD}_{3} \mathrm{CN}$ and allowed to equilibrate for seven days.

Geometry optimisations were carried out at the B3LYP/6-311++G(d,p) level of theory. Harmonic vibrational frequencies were computed at the same level used for the geometry optimisations in order to classify the stationary points either as local minima or transition states (TS). Calculations were performed using the Gaussian09 programme. $^{1}$

The Atoms in Molecules (AIM) methodology ${ }^{2,3}$ was used to analyze the electron density of the systems with the AIMAll program. ${ }^{4}$ The Natural Bond Orbital (NBO) ${ }^{5}$ method was employed to analyse charge-transfer interactions between occupied and unoccupied orbitals NBO-3 program.

The NCI (Non-Covalent Interactions) index, based on the reduced gradient of the electron density, has been calculated to identify attractive and repulsive interactions with the NCI program ${ }^{6}$ and plotted with the VMD program. ${ }^{7}$ 


\section{Supplementary data}

1. NMR spectra for $\mathrm{C}_{6}-\mathrm{C}_{14}$ OHLs in $\mathrm{CDCl}_{3}$ at 7 day time point

$\mathbf{C}_{\mathbf{6}} \mathrm{CDCl}_{3}$ time 7 days

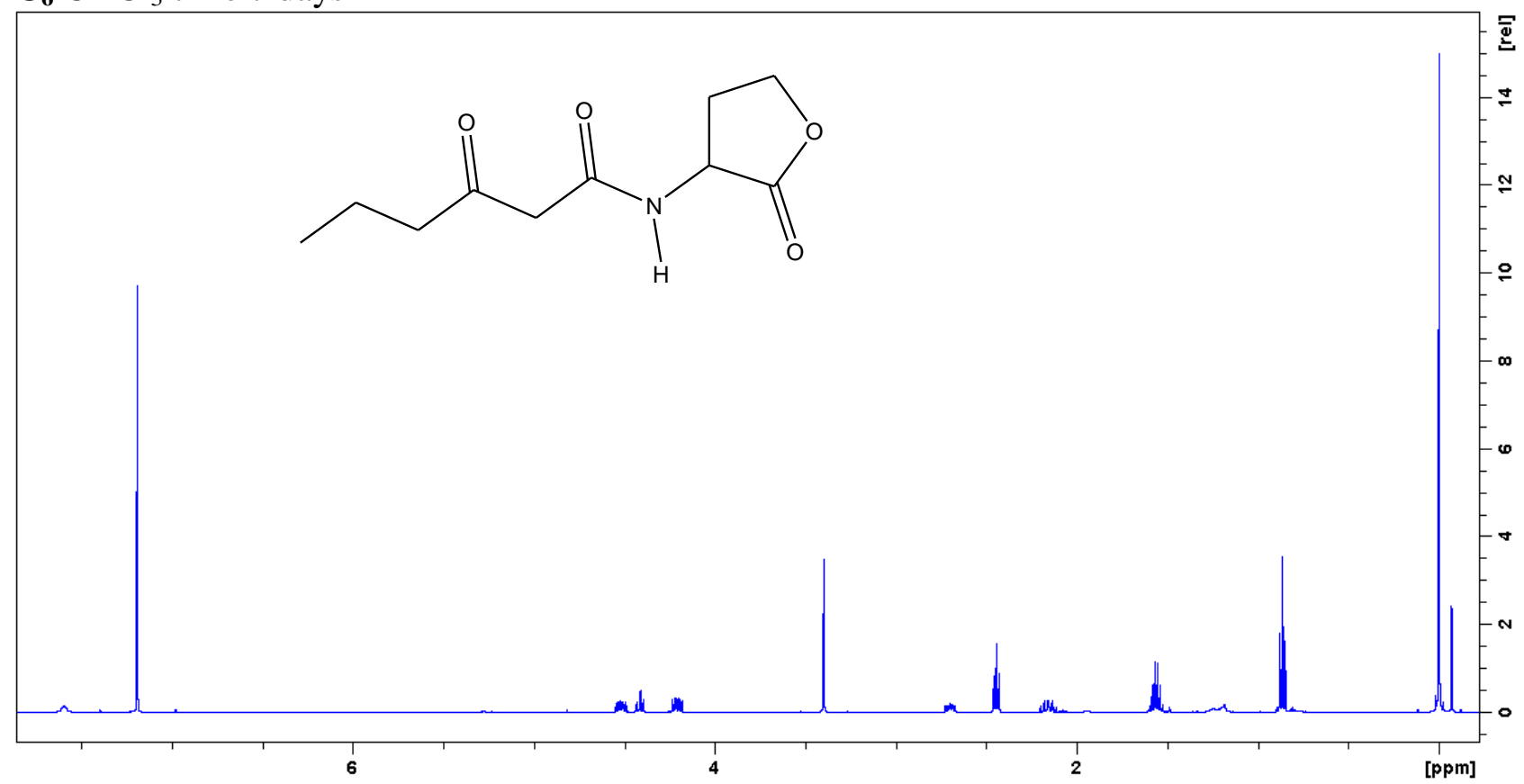

$\mathbf{C}_{\mathbf{8}} \mathrm{CDCl}_{3}$ time 7 days

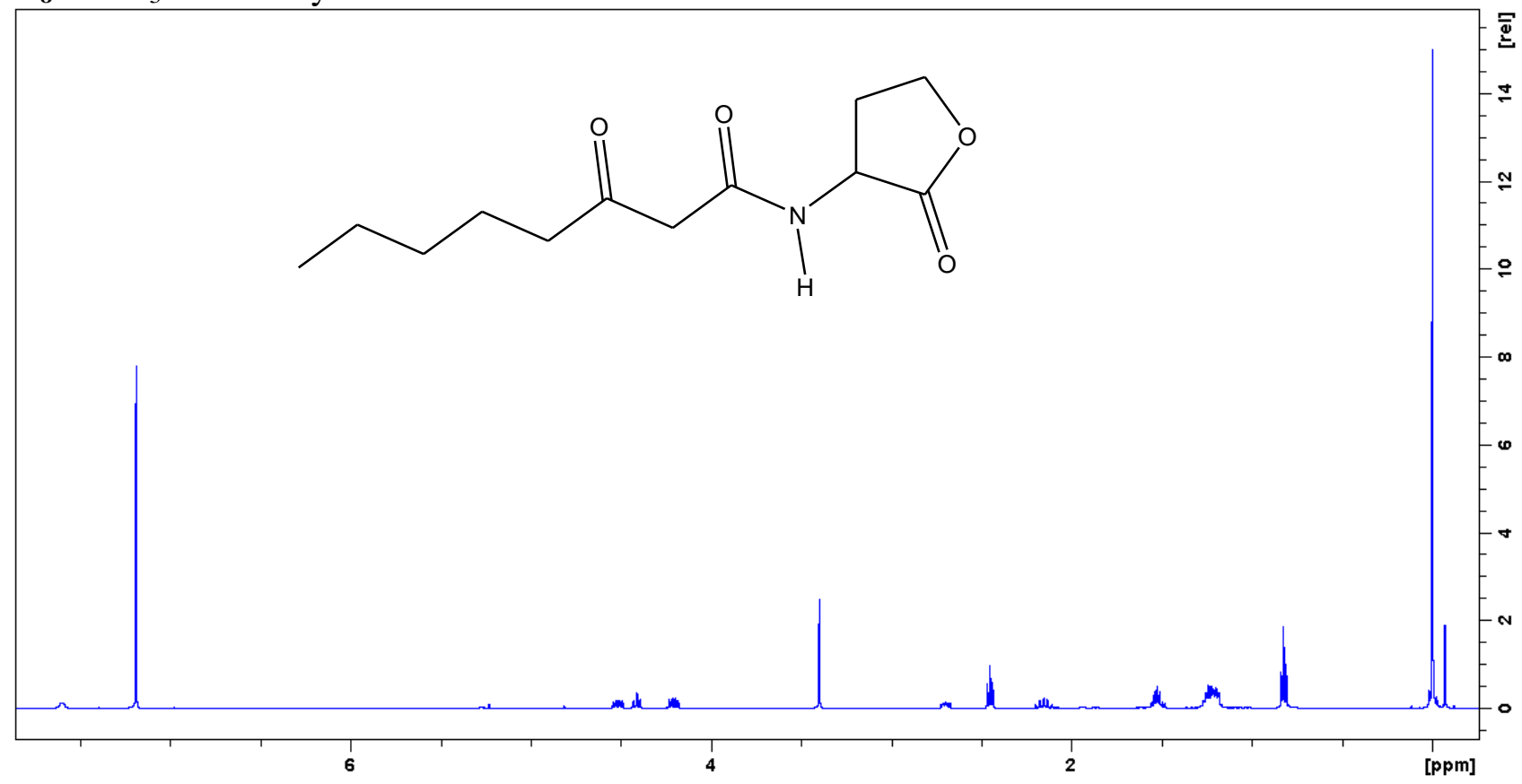


$\mathbf{C}_{\mathbf{1 0}} \mathrm{CDCl}_{3}$ time 7 days

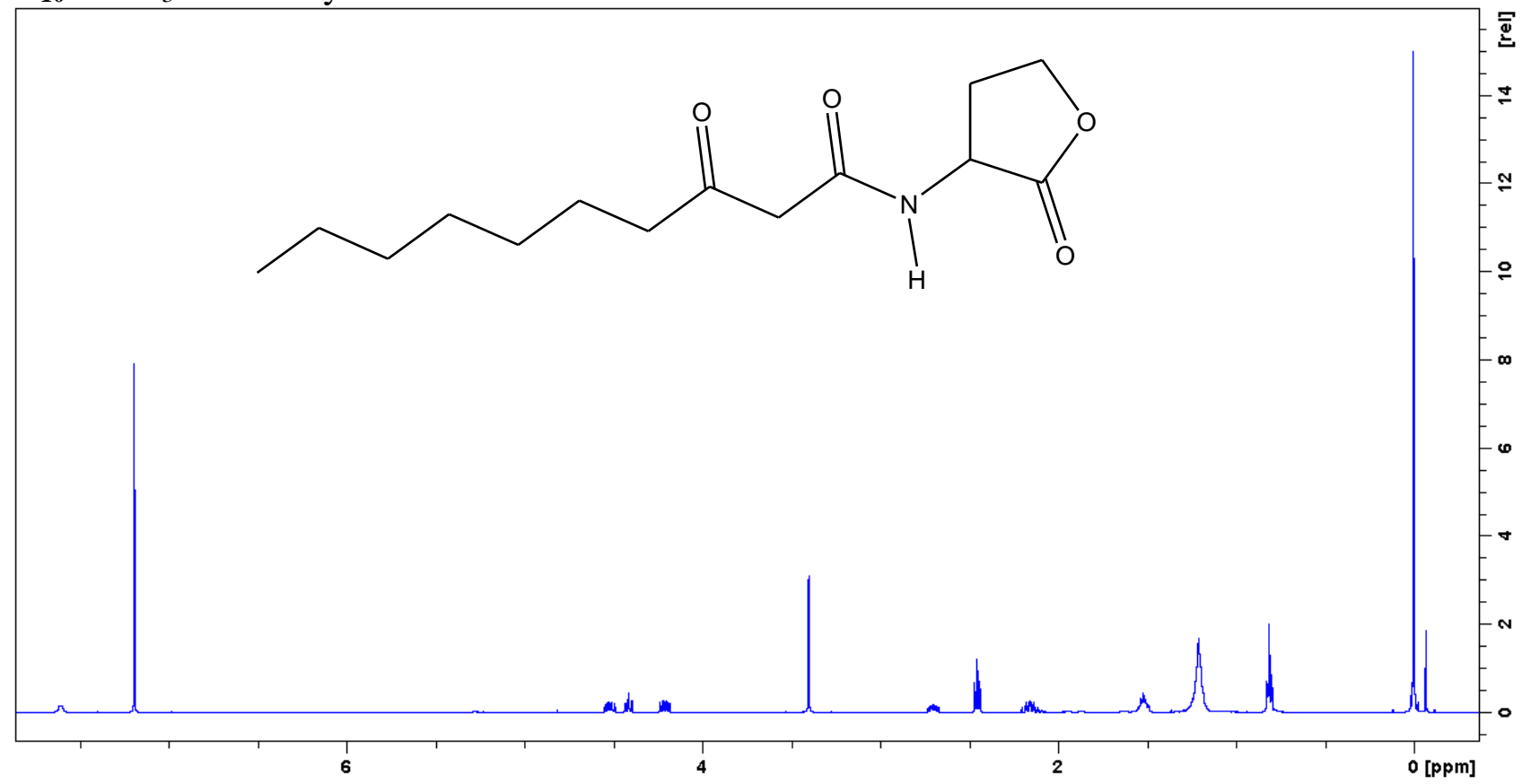

$\mathbf{C}_{\mathbf{1 2}} \mathrm{CDCl}_{3}$ time 7 days

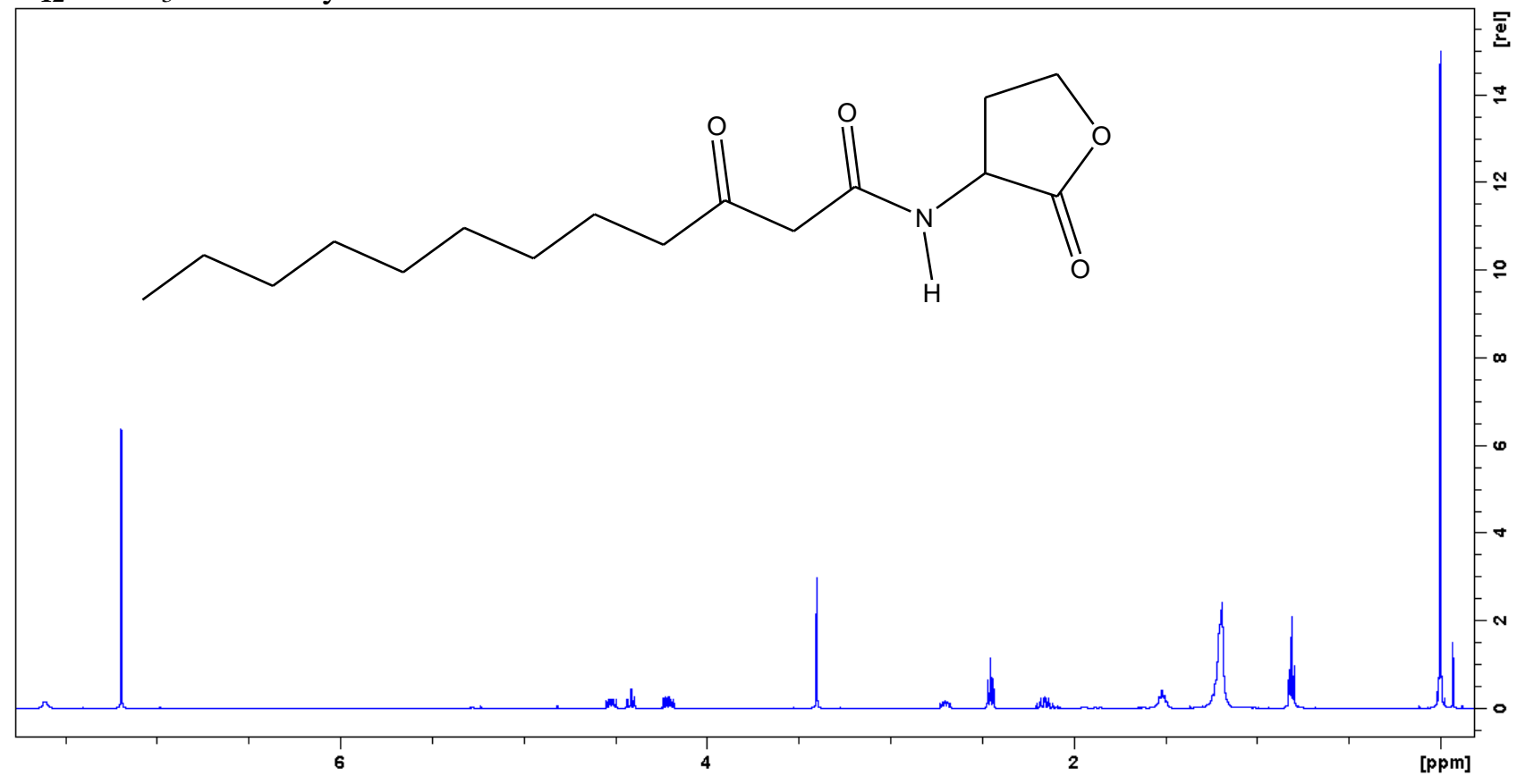


$\mathbf{C}_{\mathbf{1 4}} \mathrm{CDCl}_{3}$ time 7 days

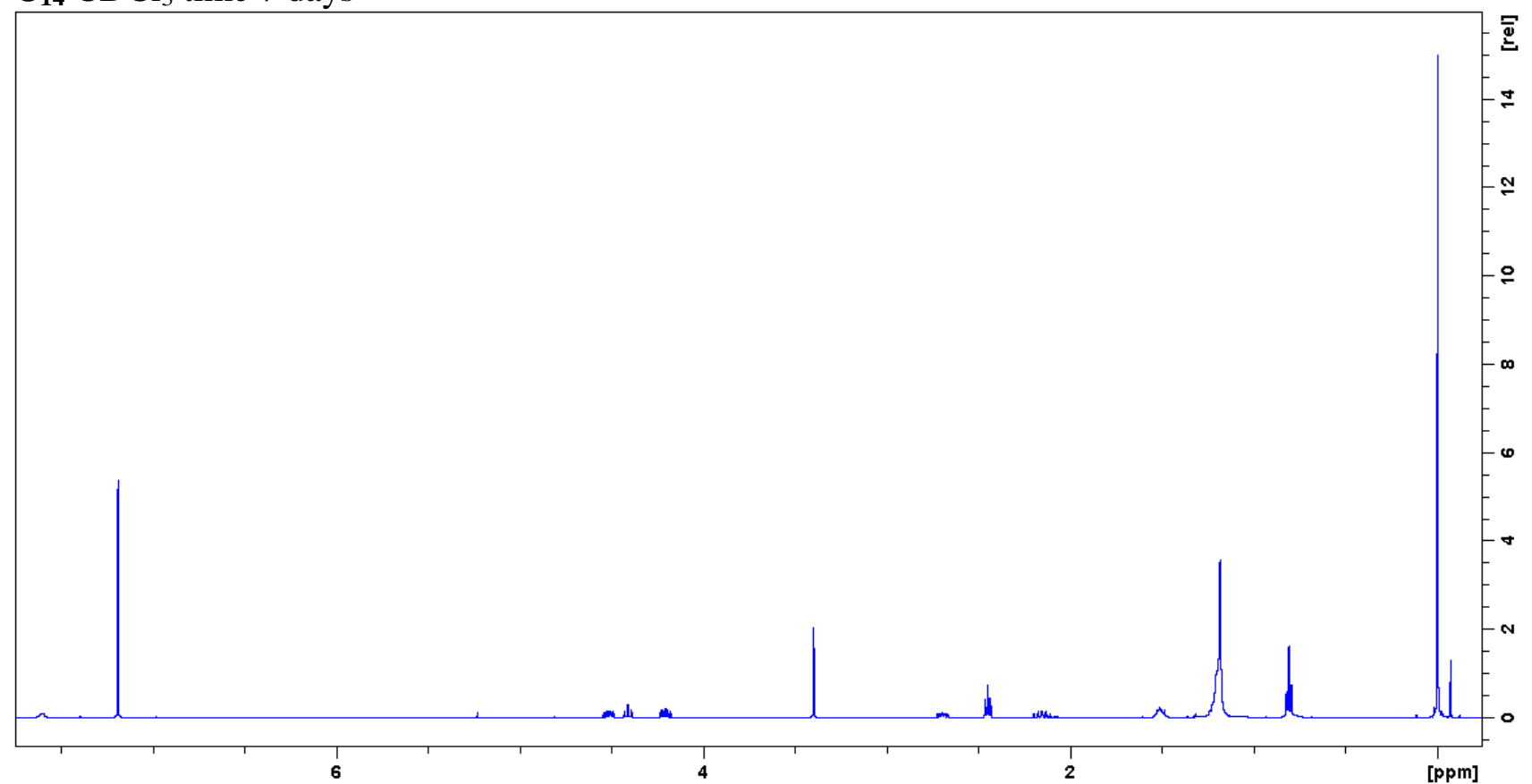


2. NMR spectra for $\mathrm{C}_{6}-\mathrm{C}_{14} \mathrm{OHLs}$ in $\mathrm{CD}_{3} \mathrm{CN}$ at 7 day time point

$\mathbf{C}_{6} \mathrm{CD}_{3} \mathrm{CN}$ time 7 days

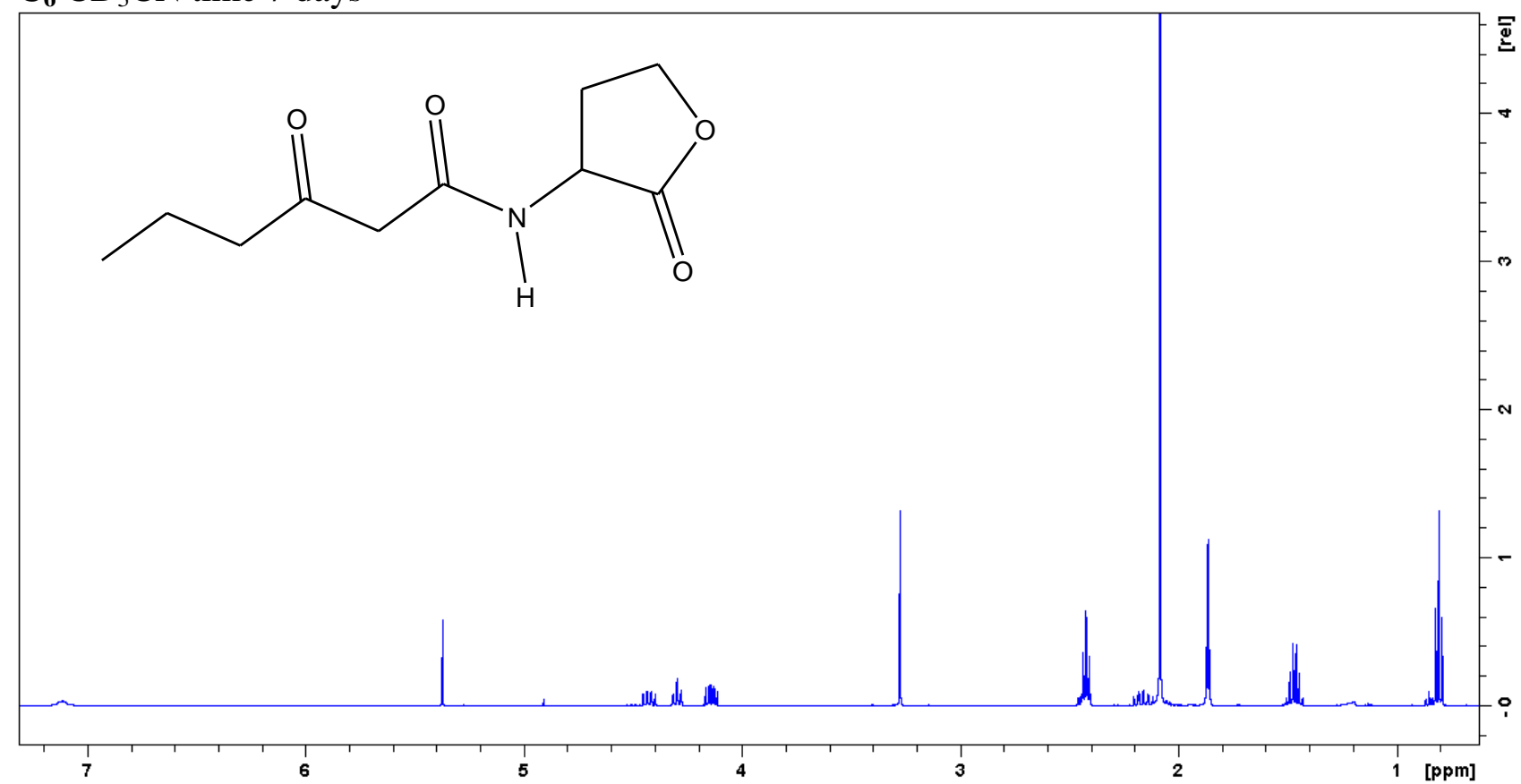

$\mathbf{C}_{\mathbf{8}} \mathrm{CD}_{3} \mathrm{CN}$ time 7 days

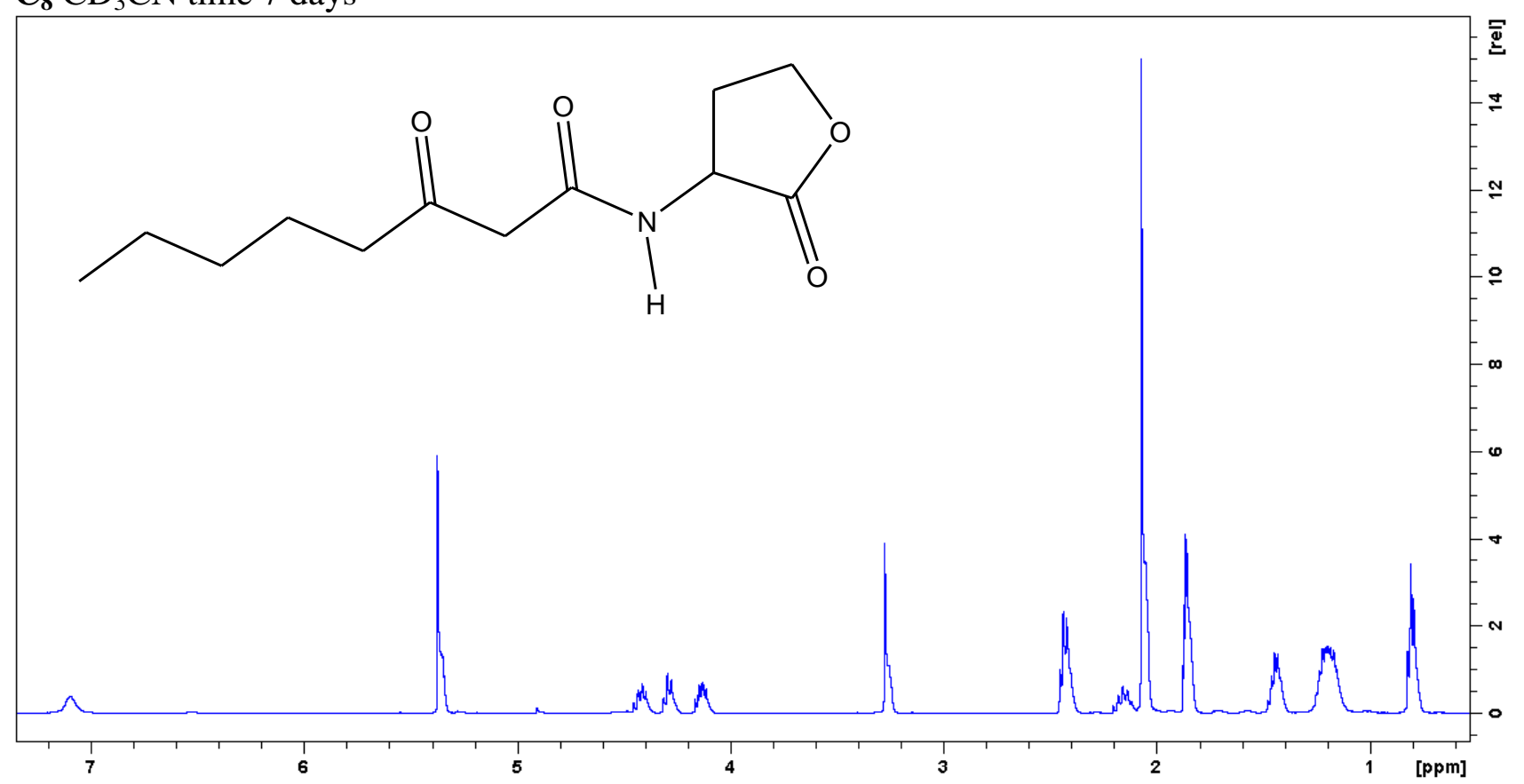


$\mathbf{C}_{\mathbf{1 0}} \mathrm{CD}_{3} \mathrm{CN}$ time 7 days

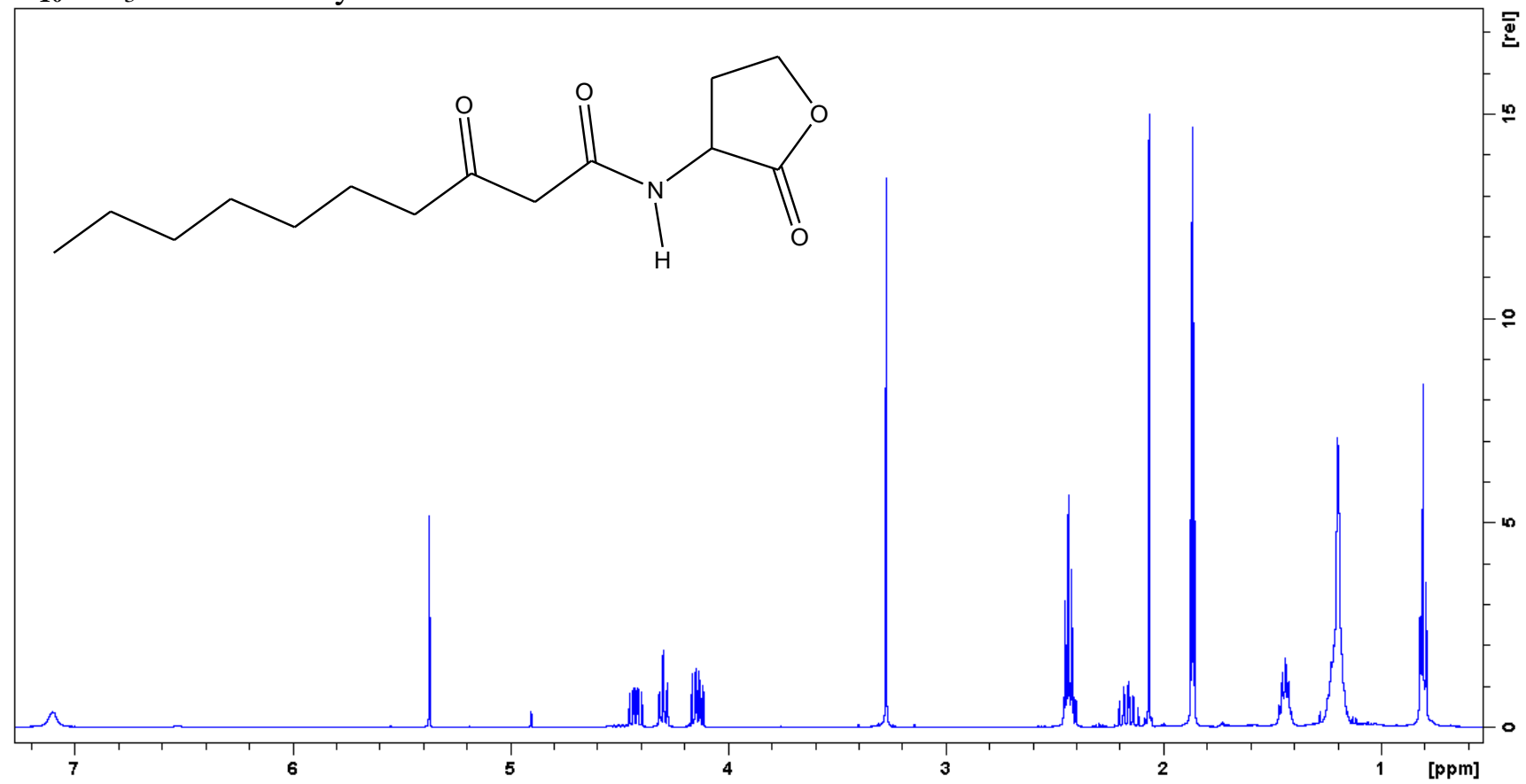

$\mathbf{C}_{\mathbf{1 2}} \mathrm{CD}_{3} \mathrm{CN}$ time 7 days

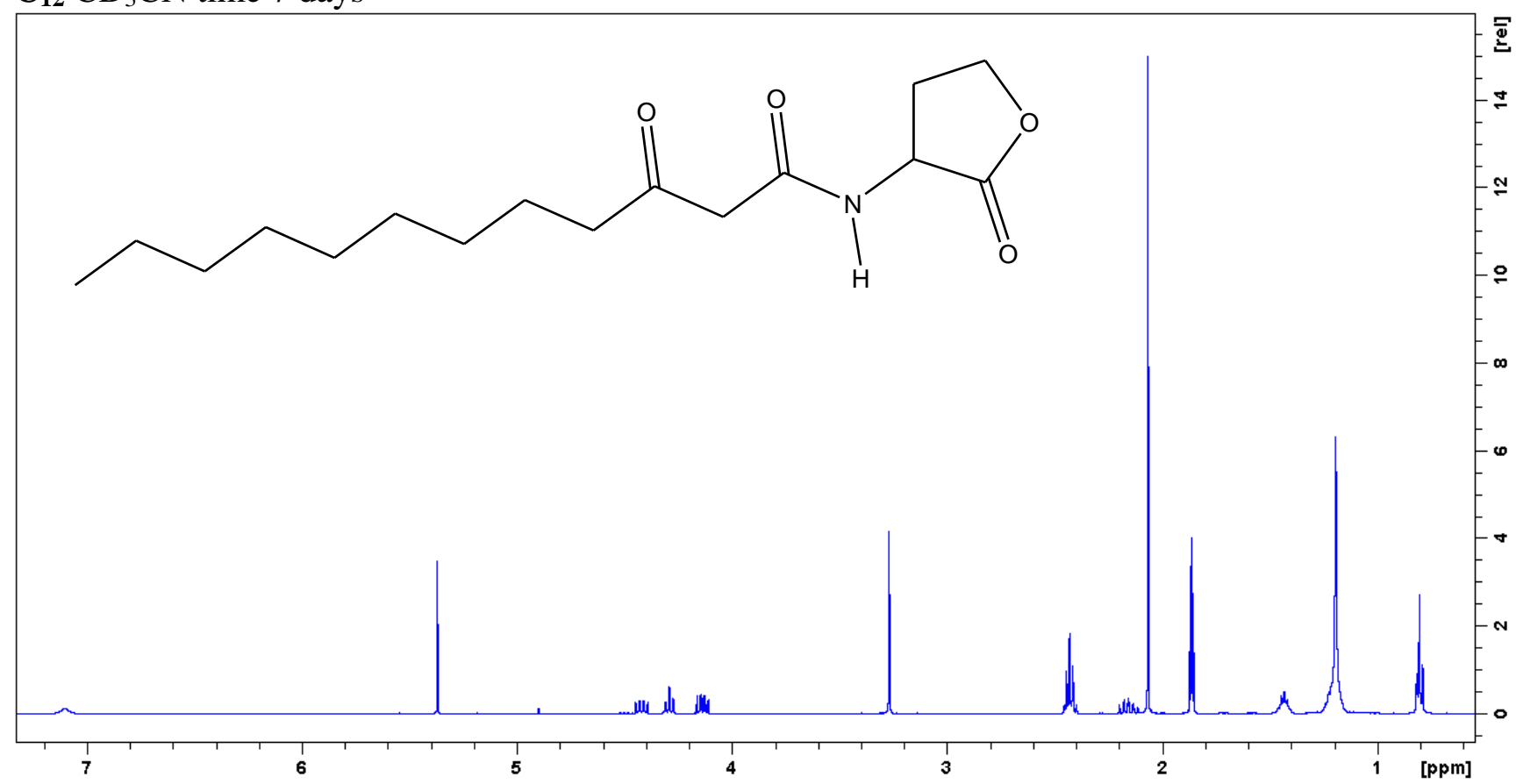




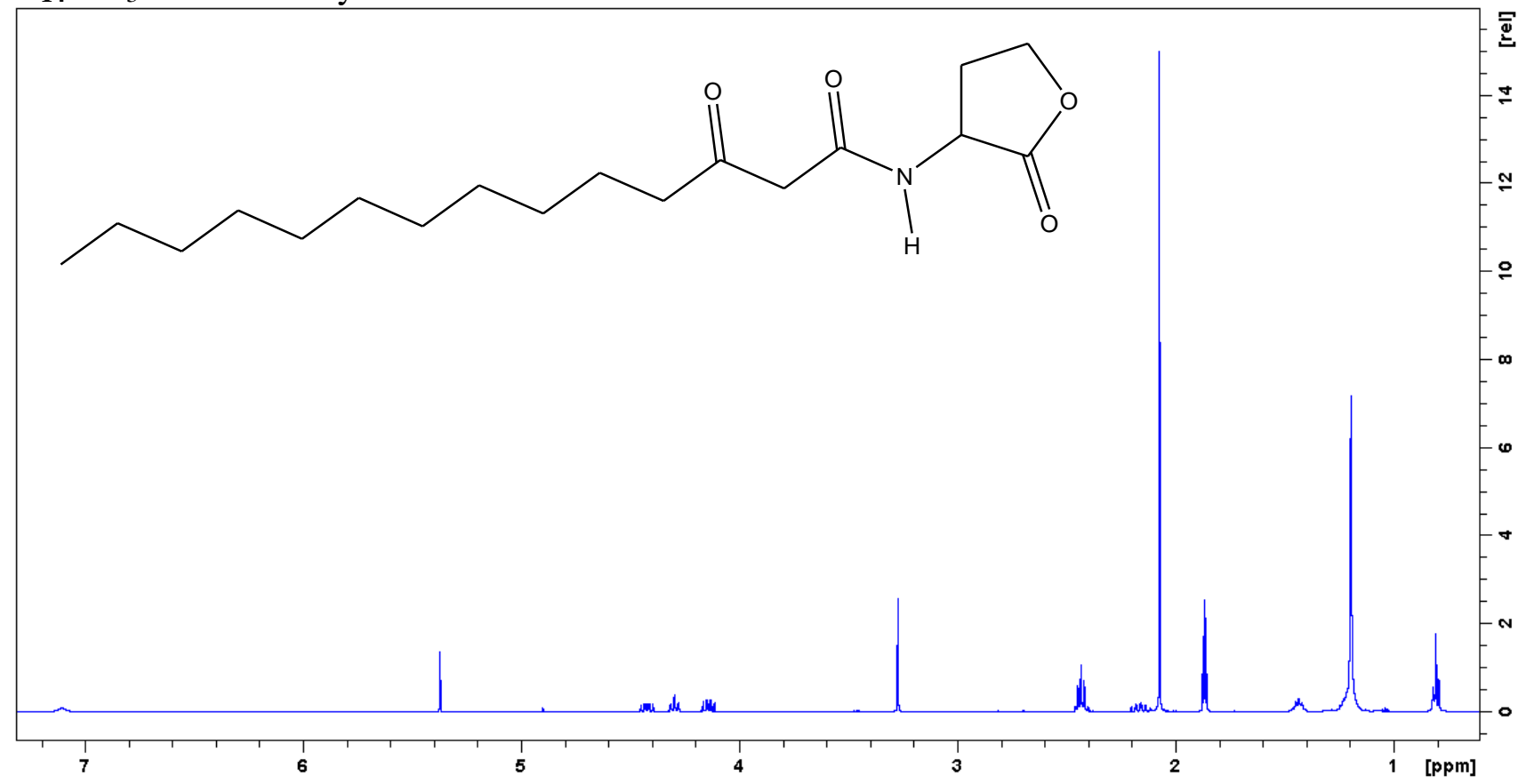

Cartesian coordinates of all the compounds studied in gas phase, chloroform, acetonitrile and water.

$\begin{array}{lrrr}\text { Gas phase } & & \\ \text { A } & & & \\ \text { O } & 2.33198 & 4.91195 & -0.00817 \\ \mathrm{C} & 3.19507 & 3.74137 & -0.09279 \\ \mathrm{C} & 2.30229 & 2.62007 & -0.63308 \\ \mathrm{C} & 0.94629 & 3.01714 & -0.03939 \\ \mathrm{H} & 4.02824 & 4.00550 & -0.74136 \\ \mathrm{H} & 3.57213 & 3.52985 & 0.91100 \\ \mathrm{H} & 2.25200 & 2.65503 & -1.72451 \\ \mathrm{H} & 2.62709 & 1.62712 & -0.32733 \\ \mathrm{H} & 0.89888 & 2.67578 & 1.00405 \\ \mathrm{C} & 1.03555 & 4.54428 & -0.02123 \\ \mathrm{O} & 0.11973 & 5.31935 & -0.03911 \\ \mathrm{~N} & -0.24813 & 2.60309 & -0.73992 \\ \mathrm{H} & -0.88124 & 3.33995 & -1.02140 \\ \mathrm{C} & -0.67508 & 1.30592 & -0.69977 \\ \mathrm{C} & -2.83204 & -0.09403 & -0.81039 \\ \mathrm{C} & -3.12798 & -0.00075 & 0.67468 \\ \mathrm{H} & -2.16778 & -0.10354 & 1.19281 \\ \mathrm{H} & -3.46724 & 1.02184 & 0.88757 \\ \mathrm{C} & -4.13427 & -1.03445 & 1.17300 \\ \mathrm{H} & -3.77855 & -2.04794 & 0.98035\end{array}$

$\begin{array}{lrrr}\text { Chloroform } & & \\ \text { A } & & & \\ \text { O } & -3.96391 & 0.65942 & -0.17662 \\ \text { C } & -4.00808 & -0.74266 & -0.59438 \\ \text { C } & -2.66810 & -1.32995 & -0.14812 \\ \text { C } & -1.74952 & -0.10683 & -0.27752 \\ \text { H } & -4.87722 & -1.18865 & -0.11664 \\ \text { H } & -4.13589 & -0.75957 & -1.67821 \\ \text { H } & -2.71342 & -1.65225 & 0.89494 \\ \text { H } & -2.35145 & -2.16921 & -0.76493 \\ \text { H } & -1.44478 & 0.00783 & -1.32492 \\ \text { C } & -2.69798 & 1.04755 & 0.04740 \\ \text { O } & -2.40439 & 2.14094 & 0.45741 \\ \text { N } & -0.57022 & -0.05444 & 0.55675 \\ \text { H } & -0.57260 & 0.59008 & 1.33451 \\ \text { C } & 0.58300 & -0.68362 & 0.20709 \\ \text { C } & 3.08168 & -0.27858 & 0.45286 \\ \text { C } & 3.18162 & 0.96433 & -0.40885 \\ \text { H } & 2.37869 & 0.91339 & -1.15358 \\ \text { H } & 2.92833 & 1.82140 & 0.22852 \\ \text { C } & 4.53747 & 1.15997 & -1.08057 \\ \text { H } & 4.77391 & 0.32258 & -1.74013\end{array}$

\begin{tabular}{lccc|} 
Acetonitrile & & \\
A & & & \\
O & 2.00473 & 4.71253 & 0.64474 \\
C & 3.04345 & 4.16330 & -0.22887 \\
C & 2.32157 & 3.14781 & -1.11468 \\
C & 1.20246 & 2.66342 & -0.18424 \\
$\mathrm{H}$ & 3.48011 & 4.99999 & -0.76866 \\
$\mathrm{H}$ & 3.79818 & 3.70122 & 0.40936 \\
$\mathrm{H}$ & 1.89559 & 3.63900 & -1.99317 \\
$\mathrm{H}$ & .97825 & 2.34477 & -1.44627 \\
$\mathrm{H}$ & 1.56905 & 1.87854 & 0.48393 \\
$\mathrm{C}$ & 0.93678 & 3.89681 & 0.69133 \\
$\mathrm{O}$ & -0.04607 & 4.14760 & 1.34118 \\
$\mathrm{~N}$ & 0.01541 & 2.14742 & -0.81984 \\
$\mathrm{H}$ & -0.46240 & 2.73238 & -1.49040 \\
$\mathrm{C}$ & -0.47846 & 0.90658 & -0.56716 \\
$\mathrm{C}$ & -2.67337 & -0.34034 & -0.58346 \\
$\mathrm{C}$ & -3.49111 & 0.38451 & 0.46409 \\
$\mathrm{H}$ & -2.79804 & 0.96089 & 1.08842 \\
$\mathrm{H}$ & -4.08587 & 1.13895 & -0.06715 \\
$\mathrm{C}$ & -4.38201 & -0.51548 & 1.31435 \\
$\mathrm{H}$ & -3.79010 & -1.24791 & 1.86772
\end{tabular}
Water 


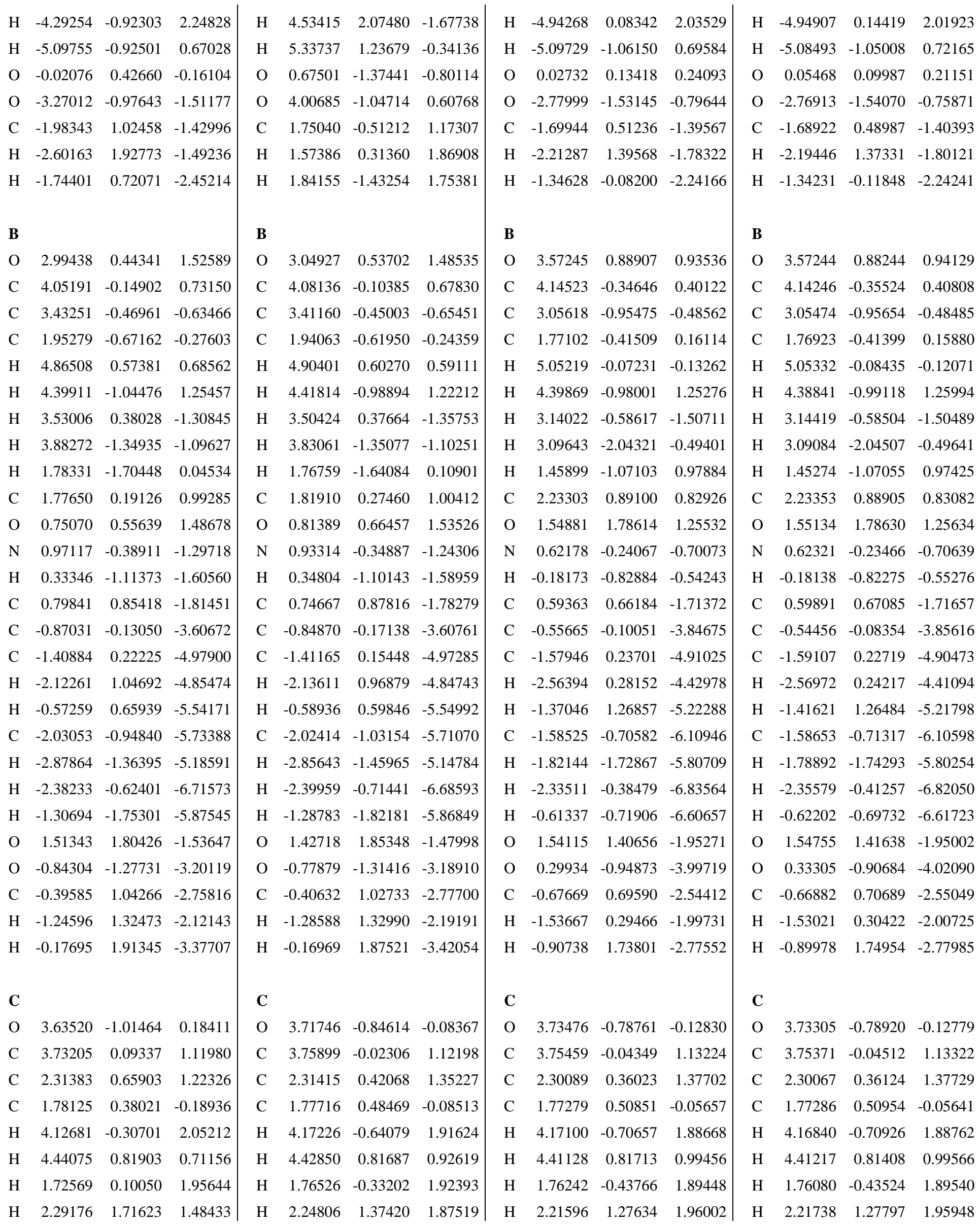




\begin{tabular}{|c|c|c|c|c|c|c|c|c|c|c|c|c|c|c|c|}
\hline $\mathrm{H}$ & 3691 & 16854 & 86472 & $\mathrm{H}$ & 04394 & 4166 & 1 & $\mathrm{H}$ & 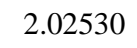 & 516 & & $\mathrm{H}$ & 02628 & & \\
\hline $\mathrm{O}_{2}$ & 2.18669 & .72788 & -1.37990 & 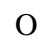 & 2.34697 & -1.16397 & .82718 & $\mathrm{O}$ & .38734 & 148 & -1.90091 & ) & .38644 & 1.01074 & -1.90097 \\
\hline & .06739 & .67372 & -0.4 & I & .08485 & -0.57072 & 426 & [ & .09099 & -0.53643 & 6190 & H & -0.09220 & -0.53240 & 06780 \\
\hline $\mathrm{C}$ & .43856 & 72 & 43 & $\mathrm{C}$ & 50 & 92 & .65874 & 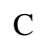 & 66 & 56 & 3380 & 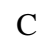 & & 096 & 831 \\
\hline 7 & .0 & 0 & & $\mathrm{C}$ & 2 & 98 & 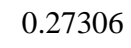 & $\mathrm{C}$ & & & 4 & 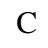 & & & 0.27444 \\
\hline $\mathrm{H}$ & -3.9 & 0.8 & & $\mathrm{H}$ & & & & Н & & & 5040 & H & & 66 & 269 \\
\hline $\mathrm{H}$ & 4.57260 & 0.53512 & 63 & $\mathrm{H}$ & -4.5 & 700 & . & $\mathrm{H}$ & -4. & 57 & 75 & I & -4 & 31 & 147 \\
\hline $\mathrm{C}$ & -4.68491 & 22483 & .062 & $\mathrm{C}$ & 237 & .13613 & 704 & C & -4.69983 & 21 & 9866 & E & 359 & 03 & 10 \\
\hline $\mathrm{H}$ & 93 & 20 & 1 & $\mathrm{H}$ & 69 & -1 & 10 & 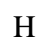 & 45 & 4 & 70 & $\mathrm{H}$ & -4 & 2 & 74 \\
\hline $\mathrm{O}$ & -2.00962 & .20631 & 86 & $\mathrm{O}$ & -1.9 & 698 & 40 & 0 & 80 & -1. & & ) & & -1 . & oo \\
\hline C & -1.9 & 96 & 64 & $\mathrm{C}$ & 76 & 649 & 8 & $\mathrm{C}$ & -1 & 12 & 32 & & -1 & 55 & 960 \\
\hline $\mathrm{H}$ & -2.4 & 036 & & $\mathrm{H}$ & & & & & & & & I & & & \\
\hline $\mathrm{H}$ & 4 & 0.9 & -1 & $\mathrm{H}$ & -2 . & 8 & 05 & $\mathrm{H}$ & -2 & & & & & & \\
\hline D & & & & D & & & & & & & & & & & \\
\hline $\mathrm{O}$ & 274 & 17 & 51 & 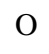 & 09 & 7 & 00 & D & 98 & & -( & 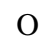 & & & 15 \\
\hline $\mathrm{C}$ & -3.93995 & .15040 & 30 & $\mathrm{C}$ & -3.9 & 388 & 62 & 0 & 02 & -0 . & 27 & r & & 34 & 3 \\
\hline $\mathrm{H}$ & -1.90552 & -0.44619 & ( & $\mathrm{H}$ & 670 & -0. & 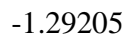 & $\mathrm{H}$ & 374 & -1 . & & $H$ & -1 & & - \\
\hline$c$ & -5.0 & 0.9 & 700 & $\mathrm{C}$ & -3 . & 1 & 353 & C & -2.87019 & 076 & 2649 & $\mathrm{C}$ & -2 & 741 & -0 \\
\hline $\mathrm{O}$ & -2.97446 & 2.09645 & -0.2 & $\mathrm{O}$ & -2.9 & 465 & 192 & $\mathrm{O}$ & -2. & 25 & 547 & D & 769 & 974 & 4449 \\
\hline IV & 9 & 89 & & & & & & $\mathrm{~N}$ & & & o & $N$ & & & \\
\hline $\mathrm{H}$ & -0.68213 & 1.50522 & 665 & $\mathrm{H}$ & -0.66157 & 640 & 904 & $\mathrm{H}$ & 309 & 404 & 5276 & 1 & 734 & 4660 & 95105 \\
\hline 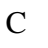 & 9 & 6 & & & & -0. & & $\mathrm{C}$ & & & & & & & \\
\hline $\mathrm{C}$ & 386 & 0.0 & 428 & $\mathrm{C}$ & 24 & 9 & 3272 & $\mathrm{C}$ & 9017 & 9076 & 2624 & 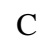 & 8917 & 7727 & 62 \\
\hline C & 23 & 297 & 00 & $\mathrm{C}$ & 500 & 2 & 35 & $\mathrm{C}$ & 47 & 84 & 52 & 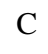 & 5 & 307 & 3823 \\
\hline $\mathrm{H}$ & 4.77301 & 30 & 236 & & 4.7 & 593 & & $\mathrm{H}$ & 4.71422 & 2767 & -0.75852 & & 1547 & & $-0.80<0$ \\
\hline $\mathrm{H}$ & 705 & 1.85152 & 651 & $\mathrm{H}$ & 841 & 05 & 272 & $\mathrm{H}$ & 529 & 192 & 663 & I & 244 & 1. & 75884 \\
\hline $\mathrm{C}$ & 110 & 62 & 20 & . & 99 & & & $\mathrm{C}$ & & & & 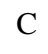 & & & 年 \\
\hline 1 & 042 & -0.88125 & 500 & . & 82 & 669 & 67 & $\mathrm{H}$ & 6 & -0 . & 0 & & 19 & -0 & 237 \\
\hline $\mathrm{H}$ & 6.11612 & 0.69561 & .05231 & 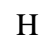 & 6.09959 & 0.09114 & 1.09466 & $\mathrm{H}$ & 692 & 0.55710 & 1.08549 & 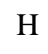 & 124 & 830 & 5213 \\
\hline$H$ & 4.69830 & 0.15427 & 1.96182 & $\mathrm{H}$ & 4.67302 & 233 & 1.96245 & $\mathrm{H}$ & 521 & -0.44031 & 1.68663 & $\mathrm{H}$ & 1827 & -0 & .67569 \\
\hline 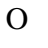 & 3.09791 & 1.16304 & -0.68649 & $\mathrm{O}$ & 3.12040 & -1.12343 & 0.78563 & O & 3.18339 & -0.63499 & -1.27500 & $\mathrm{O}$ & 3.17619 & -0.66416 & -1.27941 \\
\hline C & 1.7 & 0.6 & -0.00260 & $\mathrm{C}$ & 1.74737 & 0.63597 & -0.00263 & $\mathrm{C}$ & 1.75548 & 0.56965 & 0.17639 & C & 1.75716 & 0.56719 & .15830 \\
\hline$H$ & .68825 & .66983 & .35015 & $\mathrm{H}$ & 03 & 1.63665 & 3 & $\mathrm{H}$ & 1.65632 & 5 & 158 & & 1.66286 & 1.33685 & 001 \\
\hline
\end{tabular}




\begin{tabular}{|c|c|c|c|c|c|c|c|c|c|c|c|c|c|c|c|}
\hline 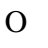 & .52942 & -1.29804 & -0.61080 & $\mathrm{O}$ & 0.55280 & -1.28639 & -0.71981 & $\mathrm{O}$ & 0.64116 & -1.01953 & -1.18762 & $\mathrm{O}$ & 0.63381 & -1.04008 & -1.17692 \\
\hline $\mathrm{H}$ & 2.17869 & -1.53927 & -0.76737 & $\mathrm{H}$ & 2.20203 & -1.49744 & -0.88584 & $\mathrm{H}$ & 2.28474 & -1.01348 & -1.47994 & $\mathrm{H}$ & 2.27555 & -1.04340 & -1.47438 \\
\hline $\mathbf{F}$ & & & & $\mathbf{F}$ & & & & $\mathbf{F}$ & & & & $\mathbf{F}$ & & & \\
\hline $\mathrm{O}$ & 3.78525 & -0.33828 & -0.29593 & $\mathrm{O}$ & 3.82827 & -0.07716 & -0.27462 & $\mathrm{O}$ & 3.78237 & -0.29270 & -0.35280 & $\mathrm{O}$ & 3.78242 & -0.29142 & -0.35334 \\
\hline $\mathrm{C}$ & 3.48014 & -1.67902 & 8193 & $\mathrm{C}$ & 3.56560 & -1.42886 & 0.22472 & $\mathrm{C}$ & 3.53550 & -1.65192 & 4471 & $\mathrm{C}$ & 53672 & -1.65131 & 4399 \\
\hline $\mathrm{C}$ & 1.95182 & -1.77030 & 0.18539 & $\mathrm{C}$ & 2.04098 & -1.54367 & 0.27987 & $\mathrm{C}$ & 2.01275 & -1.77945 & 0.20598 & $\mathrm{C}$ & 2.01412 & -1.77969 & 0.20568 \\
\hline $\mathrm{C}$ & 1.53647 & -0.31604 & 0.42515 & $\mathrm{C}$ & 1.60906 & -0.09395 & 0.51913 & $\mathrm{C}$ & 1.57029 & -0.33444 & 437 & $\mathrm{C}$ & 1.57095 & 504 & 0.45493 \\
\hline 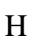 & 3.96806 & -2.37880 & -0.49363 & $\mathrm{H}$ & 4.04151 & -2.12018 & -0.46606 & $\mathrm{H}$ & 4.01453 & -2.33508 & -0.55137 & $\mathrm{H}$ & 4.01597 & -2.33379 & -0.55253 \\
\hline $\mathrm{H}$ & 3.91197 & -1.77939 & 1.18044 & $\mathrm{H}$ & 4.03442 & -1.50618 & 1.20654 & $\mathrm{H}$ & 4.00876 & -1.72447 & 1.12411 & $\mathrm{H}$ & 4.01026 & -1.72347 & 1.12323 \\
\hline $\mathrm{H}$ & 1.58487 & -2.09242 & -0.79248 & $\mathrm{H}$ & 1.64999 & -1.88685 & 3085 & I & 1.62122 & -2.1 & -0.75423 & $\mathrm{H}$ & 256 & -2 & 52 \\
\hline $\mathrm{H}$ & 1.57465 & -2.45809 & 0.94195 & $\mathrm{H}$ & 1.70573 & -2.22588 & 1.05979 & $\mathrm{H}$ & 1.68887 & -2.46628 & 0.98620 & $\mathrm{H}$ & 1.69109 & -2.46689 & 0.98589 \\
\hline $\mathrm{H}$ & 1.54803 & -0.09062 & 1.50393 & 1 & 1.64629 & 0.14152 & 1.59329 & I & 1.6 & -0.10401 & 1.52875 & $\mathrm{H}$ & .61239 & -0.1 & 1.52933 \\
\hline $\mathrm{C}$ & 2.71780 & 0.46034 & -0.17480 & $\mathrm{C}$ & 2.75644 & 0.69510 & -0.12267 & $\mathrm{C}$ & 2.70622 & 0.46617 & -0.19082 & $\mathrm{C}$ & 2.70602 & 0.46639 & -0.19049 \\
\hline $\mathrm{O}$ & 2.73440 & 1.62840 & -0.48022 & $\mathrm{O}$ & 2.74141 & 1.86720 & -0.43571 & $\mathrm{O}$ & 2.67824 & 1.64140 & -0.50001 & $\mathrm{O}$ & 2.67708 & 1.64192 & -0.49937 \\
\hline $\mathrm{N}$ & 0.25284 & 0.00713 & -0.16971 & $\mathrm{~N}$ & 0.29918 & 0.20656 & -0.03865 & $\mathrm{~N}$ & 259 & -0.04087 & 292 & $\mathrm{~N}$ & 263 & 187 & 9152 \\
\hline $\mathrm{H}$ & 0.40603 & -0.77584 & -0.29971 & $\mathrm{H}$ & -0.34216 & -0.58538 & -0.17104 & $\mathrm{H}$ & -0.38051 & -0.83687 & -0.23150 & $\mathrm{H}$ & -0.37988 & -0.83815 & -0.23047 \\
\hline $\mathrm{C}$ & -0.44682 & 1.15022 & 0.10901 & $\mathrm{C}$ & -0.40200 & 1.34825 & 0.21029 & C & -0.45225 & 1.09675 & 82 & $\mathrm{C}$ & 235 & 50 & 170 \\
\hline $\mathrm{C}$ & -1.82258 & 1.17731 & 0.10039 & $\mathrm{C}$ & -1.78124 & 1.38664 & 0.18389 & $\mathrm{C}$ & -1.83323 & 1.13611 & 0.11609 & $\mathrm{C}$ & -1.83349 & 1.13519 & 0.11618 \\
\hline $\mathrm{H}$ & -2.29969 & 2.13817 & 0.23403 & $\mathrm{H}$ & -2.24947 & 2.35436 & 0.30053 & $\Pi$ & -2 & 394 & 520 & $\mathrm{H}$ & 083 & 11 & 3558 \\
\hline 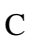 & -2.62215 & -0.00355 & -0.07612 & $\mathrm{C}$ & -2.59552 & 0.22175 & 0.00267 & $\mathrm{C}$ & -2.64933 & -0.02333 & -0.07632 & $\mathrm{C}$ & -2.64996 & -0.02359 & -0.07722 \\
\hline $\mathrm{O}$ & -2.14428 & -1.13706 & -0.27857 & $\mathrm{O}$ & -2.13165 & -0.92414 & -0.18496 & $\mathrm{O}$ & 3668 & -1.17082 & 6911 & $\mathrm{O}$ & 8759 & -1.17130 & 7053 \\
\hline $\mathrm{C}$ & -4.13574 & 0.18137 & -0.02375 & $\mathrm{C}$ & -4.10576 & 0.43880 & 0.02535 & $\mathrm{C}$ & -4.15887 & 0.19900 & -0.06390 & $\mathrm{C}$ & -4.15939 & 0.19944 & -0.06563 \\
\hline $\mathrm{H}$ & -4.37856 & 0.78043 & 0.86136 & $\mathrm{H}$ & 425051 & 1.04964 & 0.90142 & $\mathrm{H}$ & -4.40544 & 0.83512 & 070296 & $\mathrm{H}$ & -4.40597 & 0.83762 & 0.78965 \\
\hline H & -4.41355 & 0.80575 & -0.88282 & $\mathrm{H}$ & -4.35395 & 1.06335 & -0.84225 & $\mathrm{H}$ & -4.40155 & 0.79922 & -0.95011 & $\mathrm{H}$ & -4.40154 & 0.79773 & -0.95330 \\
\hline $\mathrm{C}$ & -4.92714 & -1.12367 & -0.03495 & $\mathrm{C}$ & -4.93388 & -0.84316 & 0.00948 & $\mathrm{C}$ & -4.99397 & -1.07867 & -0.04773 & $C$ & -4.99536 & -1.07765 & -0.04685 \\
\hline $\mathrm{H}$ & -4.68674 & -1.73816 & 0.83559 & $\mathrm{H}$ & -4.72528 & -1.46106 & 0.88608 & $\mathrm{H}$ & -4.79178 & -1.67419 & 0.84603 & $\mathrm{H}$ & -4.79367 & -1.67149 & 0.84817 \\
\hline $\mathrm{H}$ & -6.00096 & -0.91912 & -0.02368 & $\mathrm{H}$ & -6.00057 & -0.60457 & 0.00849 & $H$ & -6.05896 & -0.83331 & -0.05635 & $\mathrm{H}$ & -6.06014 & -0.83148 & .05585 \\
\hline$\Pi$ & -4.69656 & -1.71496 & -0.92272 & $\mathrm{H}$ & -4.71732 & -1.44376 & -0.87601 & $\mathrm{H}$ & -4.78199 & -1.70315 & -0.91778 & $\mathrm{H}$ & -4.78415 & -1.70401 & -0.91576 \\
\hline O & 0.23528 & 2.26567 & 0.39282 & $\mathrm{O}$ & 0.27545 & 2.47097 & 0.48091 & $\mathrm{O}$ & 0.21941 & 2.22242 & 0.42470 & $\mathrm{O}$ & 0.21894 & 2.22135 & 0.42580 \\
\hline 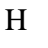 & 1.15636 & 2.21265 & 0.04989 & $\mathrm{H}$ & 1.20187 & 2.41193 & 0.14500 & $\mathrm{H}$ & 1.15032 & 2.16453 & 0.09785 & $\mathrm{H}$ & 1.15033 & 2.16332 & 0.10004 \\
\hline G & & & & y & & & & I & & & & 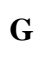 & & & \\
\hline U & 3.67865 & -1.05033 & 0.05083 & $\mathrm{O}$ & 3.64151 & -1.06827 & -0.06018 & $\mathrm{O}$ & 3.63891 & -0.98127 & -0.38041 & $\mathrm{O}$ & 3.63857 & -0.98063 & -0.38086 \\
\hline $\mathrm{C}$ & 4.02827 & 0.33485 & 0.32837 & $\mathrm{C}$ & 4.01479 & 0.26943 & 0.39840 & $C$ & 3.96374 & 0.09991 & 0.55213 & $\mathrm{C}$ & 3.96226 & 0.09769 & 0.55588 \\
\hline 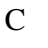 & 2.69614 & 1.04316 & 0.58383 & $\mathrm{C}$ & 2.68806 & 0.96950 & 0.69165 & $\mathrm{C}$ & 2.61572 & 0.70115 & 0.94692 & $\mathrm{C}$ & 2.61420 & 0.70127 & 0.94721 \\
\hline $\mathrm{C}$ & 1.75989 & 0.25030 & -0.33718 & $\mathrm{C}$ & 1.76409 & 0.31347 & -0.34643 & $\mathrm{C}$ & 1.78126 & 0.46289 & -0.32119 & $\mathrm{C}$ & 1.78176 & 0.46470 & -0.32249 \\
\hline $\mathrm{H}$ & 4.70802 & 0.32901 & 1.17893 & $\mathrm{H}$ & 4.65981 & 0.13992 & 1.26465 & $\mathrm{H}$ & 4.51717 & -0.34617 & 1.37505 & $\mathrm{H}$ & 4.51123 & -0.35190 & 1.37984 \\
\hline $\mathrm{H}$ & 4.55062 & 0.73121 & -0.54658 & $\mathrm{H}$ & 4.57491 & 0.74982 & -0.40637 & $\mathrm{H}$ & 4.60084 & 0.80968 & 0.02176 & $\mathrm{H}$ & 4.60316 & 0.80694 & 0.02958 \\
\hline $\mathrm{H}$ & 2.38051 & 0.91782 & 1.62301 & I & 2.33762 & 0.73314 & 1.69936 & 1 & 2.18197 & 0.15562 & 1.78867 & 1 & 2.17770 & 0.15704 & 1.78831 \\
\hline $\mathrm{H}$ & 2.71936 & 2.10561 & 0.34832 & $\mathrm{H}$ & 2.75051 & 2.05099 & 0.58326 & $\mathrm{H}$ & 2.69240 & 1.75436 & 1.21416 & $\mathrm{H}$ & 2.69252 & 1.75436 & 1.21435 \\
\hline $\mathrm{H}$ & 1.87662 & 0.62817 & -1.36340 & $\mathrm{H}$ & 1.91148 & 0.80682 & -1.31566 & $\mathrm{H}$ & 1.96998 & 1.25528 & -1.05221 & $\mathrm{H}$ & 1.97050 & 1.25819 & -1.05228 \\
\hline$C$ & 2.37529 & -1.14922 & -0.29609 & $\mathrm{C}$ & 2.35759 & -1.09044 & -0.46451 & $\mathrm{C}$ & 2.40461 & -0.81768 & -0.89178 & $\mathrm{C}$ & 2.40633 & -0.81441 & -0.89507 \\
\hline $\mathrm{O}$ & 1.82855 & -2.19452 & -0.51425 & $\mathrm{O}$ & 80919 & -2.09402 & -0.84140 & $\mathrm{O}$ & 1.92278 & -1.59392 & -1.67817 & $\mathrm{O}$ & 1.92637 & -1.58753 & -1.68608 \\
\hline 10 & 0.36158 & 0.20158 & 0.00756 & $\mathrm{~N}$ & 0.35354 & 0.26478 & -0.05721 & $\mathrm{~N}$ & 0.35581 & 0.37945 & -0.15281 & $\mathrm{~N}$ & 0.35615 & 0.37979 & -0.15518 \\
\hline $\mathrm{H}$ & -0.05888 & -0.70718 & 0.15541 & $\mathrm{H}$ & 0.05940 & -0.61595 & 0.21956 & $\mathrm{H}$ & 0.03270 & 5322 & 0.42603 & $\mathrm{H}$ & -0.03093 & -0.34703 & 0.43204 \\
\hline
\end{tabular}




\begin{tabular}{|c|c|c|c|c|c|c|c|c|c|c|c|c|c|c|c|}
\hline$C$ & .43973 & 9 & 2 & $\mathrm{C}$ & 63 & 9 & 1 & $C$ & 4 & 51 & 73156 & $\mathrm{C}$ & -0 & 4 & \\
\hline & 4.83833 & .87215 & -049689 & $\mathrm{C}$ & -481301 & -0.93483 & .43490 & $C$ & 4.76381 & -1.06731 & -0.21640 & $\mathrm{C}$ & -4.76522 & -1.06440 & -021565 \\
\hline & 17 & .60981 & -1.53319 & $\mathrm{H}$ & -4.60666 & -0.72938 & -1.48762 & $\mathrm{H}$ & 856 & -1.0 & 277 & $\mathrm{H}$ & & 932 & 9278 \\
\hline 1 & .55933 & 92100 & -0.35123 & $\mathrm{H}$ & 36 & 318 & 556 & $\mathrm{H}$ & 791 & 026 & 670 & I & 25 & 929 & 0201 \\
\hline & ( & 9 & 1 & $P$ & 18 & -1.0 & 10 & $\mathrm{O}$ & 97 & 31 & & $\mathrm{O}$ & & & 37 \\
\hline 11 & -2.6 & 398 & 14 & $\mathrm{H}$ & -2 & -1.7 & 946 & Н & -2.47498 & -1 . & 1.41286 & H & & 780 & 1705 \\
\hline & -1.89847 & .14936 & -0.01894 & - & -1.91822 & 1.16057 & - & $\mathrm{C}$ & -1.94921 & 122 & 7410 & $\mathrm{C}$ & -1 & 816 & 7740 \\
\hline$\Pi$ & -2.43472 & 2.07157 & -0.19647 & $\mathrm{H}$ & -2.48301 & 2.04493 & .40773 & $\mathrm{H}$ & -2.55406 & 1.86847 & 53 & I & & & 651 \\
\hline $\mathrm{C}$ & -4.1 & 0 & 0.4 & $\mathrm{C}$ & -4 & 0 & 63 & $C$ & 942 & 573 & 18 & $\mathrm{C}$ & -4 & 507 & 43674 \\
\hline$\Pi$ & & & & $\mathbf{H}$ & & & & I & & & & & & & \\
\hline ( & 58 & 43 & 33 & $\mathrm{O}$ & -4 & 9 & 84 & $\mathrm{O}$ & 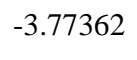 & & -( & $\mathrm{O}$ & & & 20 \\
\hline $\mathrm{C}$ & -4.0 & -0.88316 & 809 & $\mathrm{C}$ & -4.0 & -0.87107 & 369 & $\mathrm{C}$ & 827 & 554 & & z & & 94 & 870 \\
\hline$C$ & -2.61814 & 330 & 0.17569 & $\mathrm{C}$ & -2.6 & 243 & 71 & $\mathrm{C}$ & -2 & -0 & 73 & $C$ & -2 & 37 & 680 \\
\hline C & -1.79944 & .06572 & -0.2 & $\mathrm{C}$ & -1 & 77 & 80 & C & 44 & 40 & 53 & 5 & 59 & 71 & 132 \\
\hline $\mathrm{H}$ & -48 & 71 & 05 & $\mathrm{H}$ & -4 & -1 & 0 . & $\mathrm{H}$ & 437 & -0 & 0 & 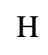 & 96 & 60 & 899 \\
\hline 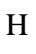 & 70 & 644 & 92 & 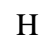 & -4 & -1. & 91 & I & 3 & 34 & 15 & $\mathrm{H}$ & & & 238 \\
\hline $\mathrm{H}$ & -2.59561 & .33609 & 683 & $\mathrm{H}$ & -2.6 & -1.25832 & 1.3 & $\mathrm{H}$ & -2.92062 & 37 & 89 & $\mathrm{I}$ & 14 & 28 & 1852 \\
\hline$C$ & 0.51238 & .50323 & T & $\mathrm{C}$ & 0.52352 & -0.50813 & 0.3 & $C$ & 0.61092 & -0 . & & 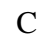 & & -0 & 09 \\
\hline$C$ & 2.99012 & -0.08447 & .24932 & $\mathrm{C}$ & 3.00611 & -0.07603 & 0.21506 & $\mathrm{C}$ & 3.04883 & -0.08236 & 0.06442 & C & 3.04906 & -0.08068 & .05814 \\
\hline$r$ & 3.82060 & 0.94589 & 576 & $\mathrm{C}$ & 297 & 101 & 495 & $\mathrm{C}$ & 908 & 24 & 19 & F & 2 & 014 & 7054 \\
\hline 11 & & & 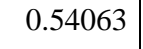 & H & 260110 & & 0.60697 & S & & & & $H$ & & & 0156 \\
\hline $\mathrm{C}$ & 5.07975 & 0.88978 & -0.75716 & $\mathrm{C}$ & 053 & 0.92457 & 192 & $\mathrm{C}$ & 5.05781 & 057 & -0.50995 & 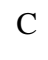 & 71 & 270 & -0.50330 \\
\hline 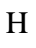 & 5 & 4 & -1.51433 & & & & & & & & & & & & \\
\hline $\mathrm{H}$ & 654 & 1.03519 & 914 & $\mathrm{H}$ & 6.00367 & 1.03423 & 800 & H & 134 & 233 & 2355 & I & 5473 & 7764 & 3034 \\
\hline $\mathrm{H}$ & 7810 & .07149 & 220 & $\mathrm{H}$ & 25 & -0.00971 & 390 & $\mathrm{H}$ & .20324 & 24 & $-1 . ?$ & $H$ & 9 & 5717 & 4737 \\
\hline$U$ & 13 & 216 & -0.20847 & $\mathrm{O}$ & 0.55736 & -1.55352 & -0.53150 & $\mathrm{O}$ & 0.69933 & -1.50224 & -0.90120 & 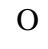 & & 9095 & -0.91733 \\
\hline $\mathrm{O}$ & 992 & .32160 & -0.27321 & $\mathrm{O}$ & 090 & -1. & 335 & $\mathrm{O}$ & 599 & -1 . & 756 & $\mathrm{O}$ & 331 & 419 & -0.91317 \\
\hline 11 & 15 & -1.79689 & -0.35705 & $\mathrm{H}$ & 2.40325 & -1.74950 & -0.47176 & $\mathrm{H}$ & 2.52531 & -1.47975 & & I & & 711 & -1 . \\
\hline s & 831 & 0.00732 & 81 & $\mathrm{C}$ & 80 & -0. & 924 & $\mathrm{C}$ & 7 & -0 & 37 & 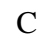 & 06 & 964 & 0.90194 \\
\hline 11 & 1.61526 & 1.02967 & 1.46750 & $\mathrm{H}$ & 1.60866 & 0.99798 & 148 & 11 & 1.63665 & 0.40923 & 507 & $\mathrm{H}$ & 810 & 025 & 1.60328 \\
\hline$H$ & 1.87293 & -0.63997 & 1.99028 & $\mathrm{H}$ & 1.86439 & -0.68235 & 1.92229 & $\mathrm{H}$ & 2.04136 & -1.30614 & 1.50424 & $\mathrm{H}$ & 2.04194 & -1.31428 & 1.48980 \\
\hline & & & & I & & & & t & & & & I & & & \\
\hline$O$ & 3.93087 & .68304 & 0.14801 & $\mathrm{O}$ & 3.93655 & .68209 & 0.18593 & $\mathrm{O}$ & 8.0030 & .65644 & -0.75911 & $\mathrm{O}$ & 3.68613 & 5559 & 0.13 \\
\hline
\end{tabular}




\begin{tabular}{|c|c|c|c|c|c|c|c|c|c|c|c|c|c|c|c|}
\hline$C$ & .98681 & 77132 & 9130 & $\mathrm{C}$ & .01458 & 7213 & 9 & C & .08989 & & & $\mathrm{C}$ & & 6 & \\
\hline $\mathrm{C}$ & 2.58787 & -1.21252 & .35152 & $\mathrm{C}$ & -2.61823 & -1.19914 & .41732 & $\mathrm{C}$ & -2.81612 & -0.82072 & 0.88491 & $\mathrm{C}$ & -2.81539 & 1503 & 891 \\
\hline $\mathrm{C}$ & .72560 & 11180 & 7446 & $c_{0}-2$ & 4533 & .14723 & 7849 & $\mathrm{C}$ & 3419 & 0115 & 7 & C & 3438 & 522 & -0.15048 \\
\hline $\mathrm{H}$ & 57 & & 1 & $\mathrm{H}$ & & & & $\mathrm{H}$ & & & & $\mathrm{T}$ & & & 7615 \\
\hline $\mathrm{H}$ & 68 & 34 & 7 & $\mathrm{H}$ & 3 & 0 & 1 & $\mathrm{H}$ & 1 & 1 & 35 & $\mathrm{H}$ & 1 & 6 & 311 \\
\hline $\mathrm{H}$ & 968 & 46 & 0 & $\mathrm{H}$ & 92 & -0 & -132443 & $\mathrm{H}$ & 337 & 9 & 2 & $\mathrm{H}$ & 6 & 80 & 98 \\
\hline $\mathrm{C}$ & 23 & 1.1 & 56 & $\mathrm{C}$ & & & & $\mathrm{C}$ & & & & $\mathrm{C}$ & & 5409 & \\
\hline $\mathrm{O}$ & 26 & 2.2 & 90 & $\Omega$ & -2.32431 & 2.23404 & 42 & $\mathrm{O}$ & -1.79558 & 88 & -1.6 & 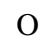 & -1.7 & .45912 & -1 \\
\hline $\mathrm{N}$ & 334 & 20411 & .35821 & 2 & -0.46975 & 0 & שדרט & 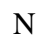 & 263 & & & a & & & 85 \\
\hline $\mathrm{H}$ & -0.3 & 1 & 0.6 & $\mathrm{H}$ & -0 . & 012 & & $\mathrm{H}$ & 8 & 61 & 622 & $\mathrm{H}$ & 83 & 530 & 1.08342 \\
\hline $\mathrm{O}$ & & & 1 & C & & & & $\mathrm{O}$ & & & & ) & & & \\
\hline $\mathrm{O}$ & 695 & 384 & 574 & 0 & 526 & -1.6 & 199 & $\mathrm{O}$ & 3.35909 & 685 & -1.16601 & 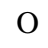 & 791 & 853 & 009 \\
\hline $\mathrm{H}$ & 25 & 81 & -0. & $\mathrm{H}$ & 35 & -2 & & $\mathrm{H}$ & & & -1 & & & 84 & \\
\hline$r$ & 1 & 74 & 0.8 & 0 & 68 & 94 & 0 & $C$ & 567 & 27 & 05 & $y$ & 24 & 39 & 0.64337 \\
\hline $\mathrm{H}$ & 76 & 93 & 0 & $\mathrm{H}$ & 25 & 1 & r & $\mathrm{H}$ & 1 & 90 & 1 & $\mathrm{H}$ & 12 & 09 & 193 \\
\hline - & 115 & .73523 & 22 & $\mathrm{H}$ & 956 & -0.73836 & 41 & $\mathrm{H}$ & 4424 & -1.24416 & 74 & I & 773 & & \\
\hline $\mathrm{H}$ & 799 & 0 & 04 & $\mathrm{H}$ & & 16 & 501 & $\mathrm{H}$ & 300 & 993 & -1 & $\mathrm{H}$ & 53 & 88 & 943 \\
\hline $\mathrm{C}$ & 34 & 1.9 & -0.0 & & & 26 & & C & & & & & & & \\
\hline $\mathrm{C}$ & -4.17475 & 1.02973 & 36 & $C$ & 33 & 315 & 17 & $\mathrm{C}$ & 978 & 16 & 34 & $\mathrm{C}$ & 71 & 156 & 246 \\
\hline $\mathrm{C}$ & -2.76221 & 1.60094 & | & $\mathrm{C}$ & -2.77028 & 1.58861 & 0.17425 & $\mathrm{C}$ & -2.77124 & 1.58653 & 0.16650 & $\mathrm{C}$ & -2.77131 & 1.58639 & 16560 \\
\hline $\mathrm{C}$ & 475 & 0.3 & 61 & $\mathrm{C}$ & 70 & & 057 & $\mathrm{C}$ & 708 & 433 & & C & 714 & 15 & 303 \\
\hline $\mathrm{H}$ & 5 & 9 & . & $\mathrm{H}$ & & 7 & 017051 & 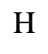 & 0 & 6 & & I & & 8 & \\
\hline $\mathrm{H}$ & -4.48318 & 0.94215 & 1.37844 & $\mathrm{H}$ & 254 & 0.93731 & 047 & $\mathrm{H}$ & 087 & 603 & 531 & 1 & 980 & 730 & 2669 \\
\hline $\mathrm{H}$ & 18 & 2 & 28 & $\mathrm{H}$ & 69 & 00 & 74 & 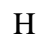 & 30 & 46 & 50 & I & 7 & 77 & 194 \\
\hline $\mathrm{H}$ & -2.53435 & 2.35346 & 0.94248 & $\mathrm{H}$ & -2.52059 & 2.34021 & 0.92318 & $\mathrm{H}$ & -2.51263 & 2.34182 & 0.90809 & H & -2.51188 & 4219 & 0.90635 \\
\hline $\mathrm{H}$ & 44 & 90 & 05 & $\mathrm{H}$ & 78 & 7 & 45 & $\mathrm{H}$ & 409 & 97 & 20 & $H$ & -1 & 093 & $770 \mathrm{C}-2$ \\
\hline C & 01 & 88 & -0.2 & $\mathrm{C}$ & -2.85071 & -0.1 & -0.27800 & $\mathrm{C}$ & -2.85914 & -0.75736 & -0.26532 & $\mathrm{C}$ & -2.85987 & 777 & -0.20502 \\
\hline $\mathrm{O}$ & -2.52225 & .81747 & -0.71235 & $\mathrm{O}$ & -2.56749 & -1.83958 & -0.7 & $\mathrm{O}$ & -2.58209 & 1991 & 337 & $\mathrm{O}$ & 335 & 104 & -0.69101 \\
\hline $\mathrm{N}$ & -0.0 & (1.42951 & -0.4 & 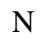 & -0.67213 & 0587 & 20 & $\mathrm{~N}$ & 年 & 9694 & & & & 9609 & -0 \\
\hline $\mathrm{C}$ & 0.36469 & -0.18140 & 0.00308 & $\mathrm{C}$ & 6333 & -0.17209 & -0.02422 & $\mathrm{C}$ & 5294 & -0.17383 & 4018 & r & 6291 & 7410 & -0.04182 \\
\hline$C$ & 2.94046 & -0.10513 & -0.04771 & $C_{1}$ & 2.94005 & -0.07810 & -0.03881 & $C_{1}+$ & 2.93916 & -0.07646 & -0.04257 & $\mathrm{C}$ & 2.93908 & -0.07663 & -0.04320 \\
\hline $\mathrm{O}$ & 29 & -0.62023 & & $\mathrm{O}$ & & -0.57820 & & $\mathrm{O}$ & 1009 & & & D & & & 1.06946 \\
\hline$C$ & 4.09547 & 0.60262 & -0.71702 & $C$ & 45 & 726 & 597 & $\mathrm{C}$ & 7 & 43 & -0.7 & 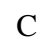 & 7 & 526 & 0207 \\
\hline $\mathrm{H}$ & 4.16651 & 0.22168 & -1.74406 & 16 & 371 & 0.20759 & -1.73059 & $\mathrm{H}$ & 3291 & 449 & -1.72507 & 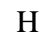 & 8399 & 0.20438 & -1.72456 \\
\hline$H$ & 79287 & 282 & 019 & $\mathrm{H}$ & 16 & 200 & 11 & $\mathrm{H}$ & 3 & 16 & 66 & $\mathrm{H}$ & 8 & 95 & -( \\
\hline
\end{tabular}




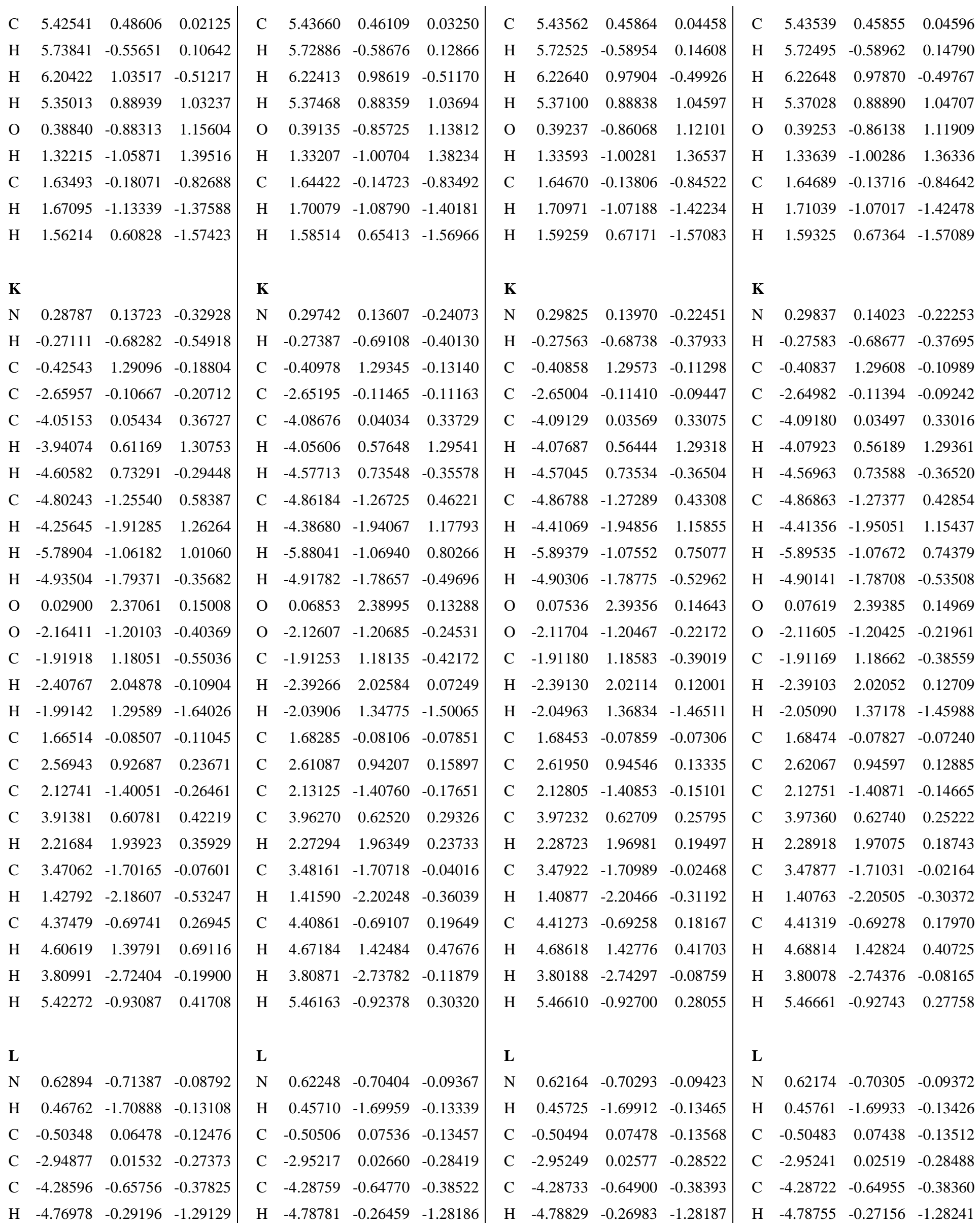




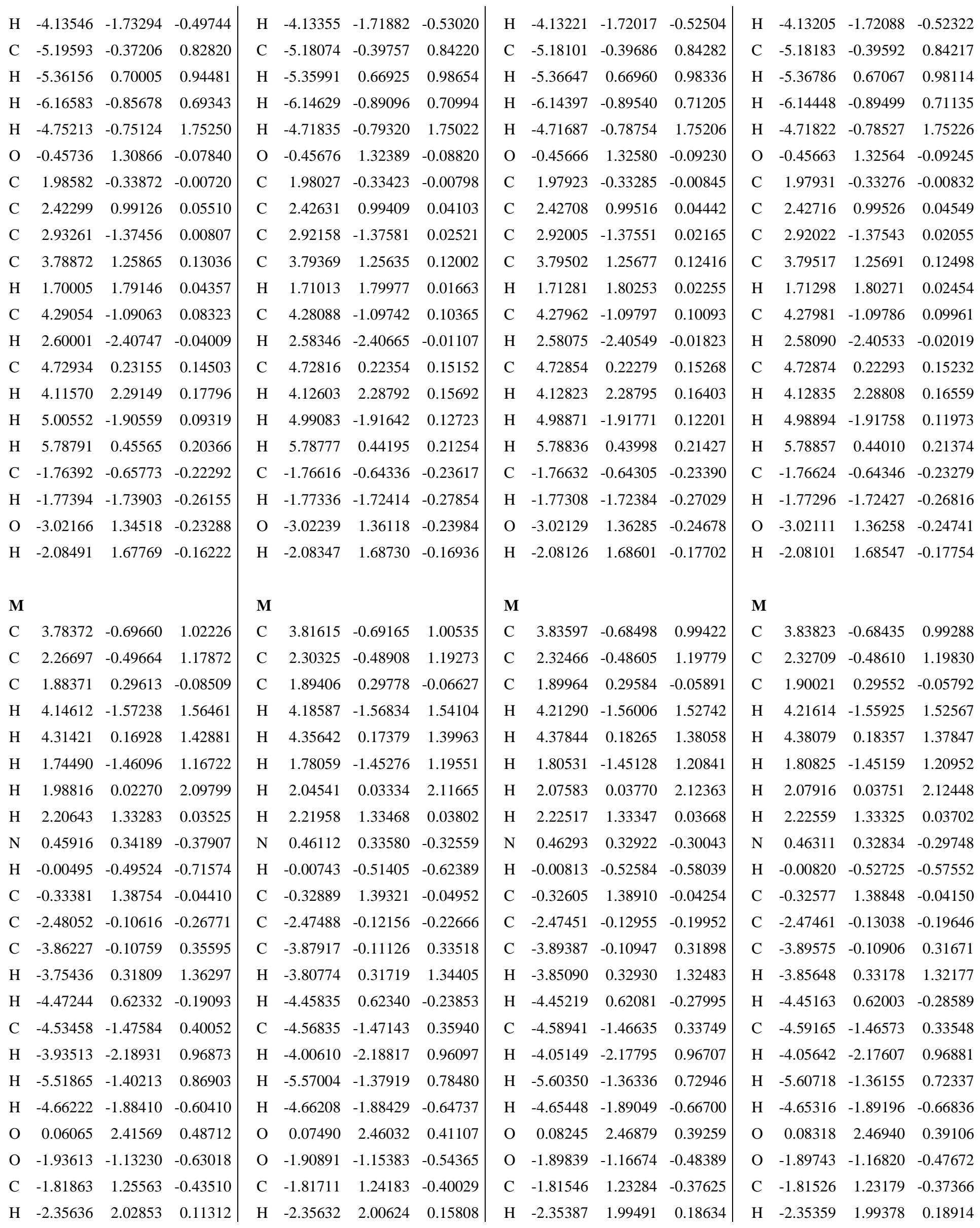




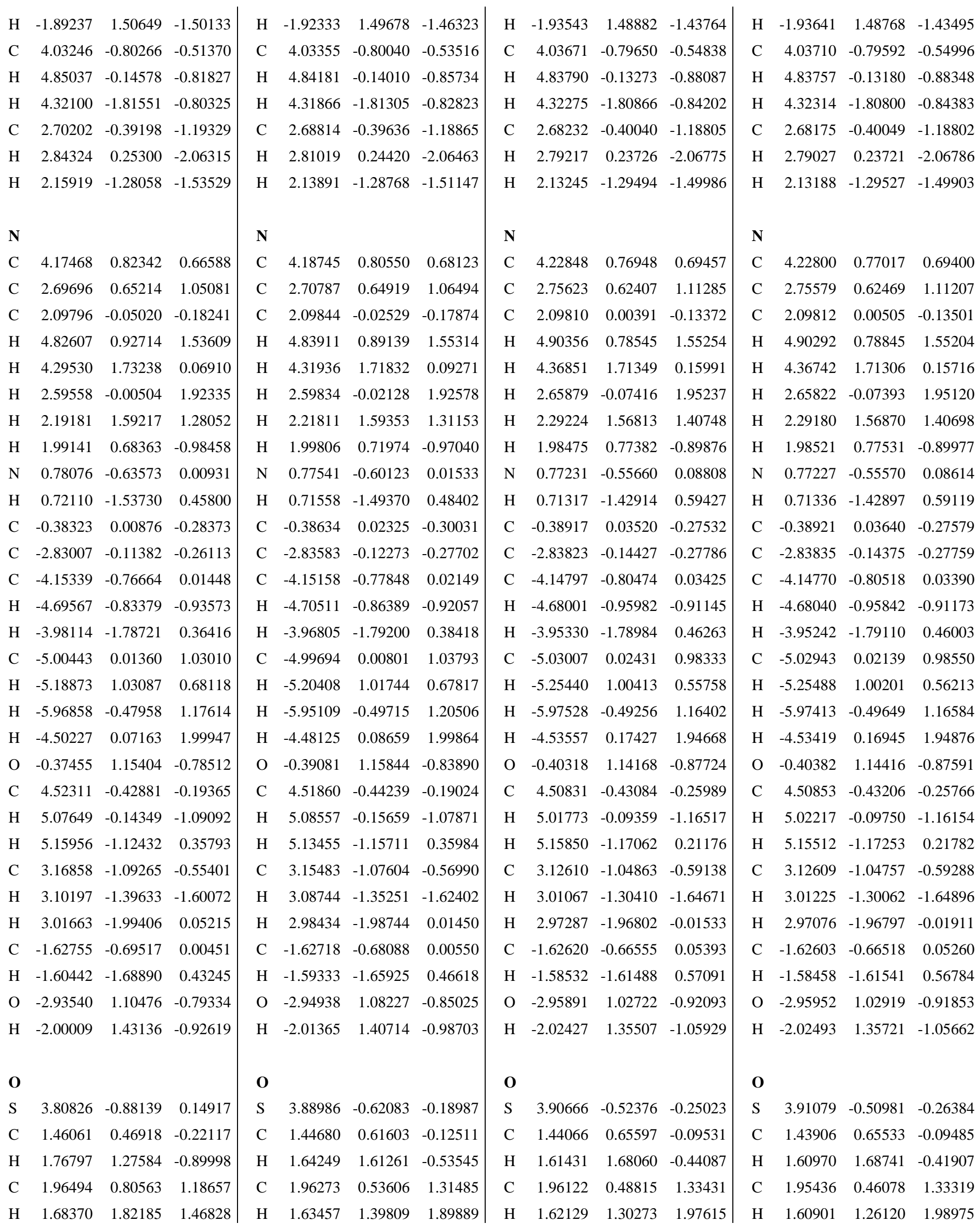




\begin{tabular}{|c|c|c|c|c|c|c|c|c|c|c|c|c|c|c|c|}
\hline $\mathrm{H}$ & 169 & 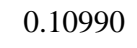 & 2 & 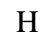 & 420 & 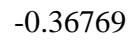 & & $\mathrm{H}$ & 73 & 65 & & H & & & \\
\hline$C$ & 3.48686 & .63521 & 15241 & C & .49084 & .47518 & 24143 & 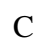 & .49006 & 0.45866 & 1.25727 & C & 3.48366 & 0.43847 & 26242 \\
\hline & 3.97861 & 48419 & .67431 & $\mathrm{H}$ & .92870 & .45696 & & & 91247 & 45709 & & & 390294 & .44056 & 7242 \\
\hline 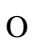 & & & & 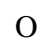 & & & & $\mathrm{O}$ & & & & 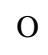 & & & 304 \\
\hline & 8 & 1 & 8 & $\mathrm{C}$ & 31 & 5 & 33 & $\mathrm{C}$ & 56 & 1 & 1 & 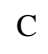 & 9 & 38 & 855 \\
\hline $\mathrm{H}$ & 46 & 9 & 0 & $\mathrm{H}$ & 7 & -( & 001803 & 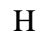 & 38 & 2 & & 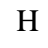 & 77 & 09 & 83 \\
\hline $\mathrm{C}$ & 0 & 80 & 93 & $\mathrm{C}$ & & & 347 & $\mathrm{C}$ & & & & C & & & 1329 \\
\hline 0 & 67 & 2.5 & 6 & $\mathrm{O}$ & -0.4 & 2.4 & 83 & $\mathrm{O}$ & 960 & 76 & 46 & 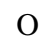 & -0 . & 2.32574 & -1.33 \\
\hline $\mathrm{C}$ & 83 & 96 & 63 & 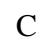 & 85 & 8 & 10 & C & 3 & 38 & 7 & $\mathrm{C}$ & & & 399 \\
\hline $\mathrm{H}$ & 98 & 1.9 & -0.5 & $\mathrm{H}$ & -2. & 1.7 & -0.99594 & $\mathrm{H}$ & -2 & 0 & -1 & $\mathrm{H}$ & & 7627 & -1 \\
\hline $\mathrm{C}$ & 54 & 12 & 0.3 & $\mathrm{C}$ & & -( & & C & & & & 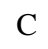 & & & \\
\hline $\mathrm{H}$ & 4.29731 & 04 & 572 & $\mathrm{H}$ & -4.4 & 01 & 14 & H & 940 & 0.95890 & 0.75607 & $I$ & -4 & 17 & (5) \\
\hline $\mathrm{H}$ & -4.90207 & 0.3 & -0. & I & -4.8 & 37 & & I & 10 & & & 1 & & & -0 \\
\hline $\mathrm{C}$ & -4.9 & -1.28841 & 0 & $\mathrm{C}$ & -4 & -1 & 00 & $\mathrm{C}$ & 736 & 13 & 13 & $C$ & -4 & 20 & 1.17672 \\
\hline $\mathrm{H}$ & 4.36591 & 32 & 19 & I & 10 & - & 2.08765 & $\mathrm{H}$ & 34 & - & $\mathrm{O}$ & 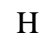 & 91 & 05 & 394 \\
\hline $\mathrm{H}$ & 82 & 09045 & 440 & $\mathrm{H}$ & -6.00243 & -0.9 & 502 & . & -6.00971 & 730 & & I & 11 & 01 & 20 \\
\hline $\mathrm{H}$ & 21 & 70 & 6 & $\mathrm{H}$ & 40 & -2 & 0 & 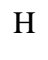 & 1 & 37 & 6 & $H$ & & & 90 \\
\hline $\mathrm{H}$ & 599 & 597 & 588 & $\mathrm{H}$ & 38 & -0. & 65 & $\mathrm{H}$ & 736 & 40 & 90 & $\mathrm{H}$ & -2 & 68 & 908 \\
\hline$C$ & -3.54775 & 1.46500 & ] & $\mathrm{C}$ & -3.55937 & -1.45447 & 0.33513 & $\mathrm{C}$ & -3.79408 & -1.21723 & 0.45910 & $\mathrm{C}$ & -3.79157 & -1.23260 & $0=1550$ \\
\hline $\mathrm{H}$ & 42 & 882 & 40 & $\mathrm{H}$ & 623 & -2.00658 & 370 & $\mathrm{H}$ & 5202 & 567 & 4058 & H & 4403 & 09 & 2779 \\
\hline $\mathrm{H}$ & -4.07958 & -1.99655 & 1.08928 & $\mathrm{H}$ & 7 & 9 & 113648 & $\mathrm{H}$ & 2 & 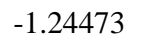 & & 1 & & 4774 & 1.21769 \\
\hline $\mathrm{O}$ & -2.50413 & 2.16662 & -0.27814 & $\mathrm{O}$ & -2.48944 & 2.15326 & 021 & $\mathrm{O}$ & 527 & 2676 & 9688 & 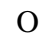 & 044 & 002 & 214 \\
\hline $\mathrm{C}$ & $-2+3$ & 0 & -0.16945 & $\mathrm{C}$ & 91 & 5 & & $C$ & 54 & 134 & 0 & $C$ & 0 & 4 & -0 \\
\hline iv & -0.32722 & 0.50702 & 0.09584 & $\mathrm{~N}$ & -0.31682 & 0.48066 & 0.08002 & $\mathrm{~N}$ & -0.26484 & 0.11543 & 0.34440 & T & -0.26667 & 0.10998 & 0.33672 \\
\hline $\mathrm{H}$ & -0.33479 & 1.51010 & 23041 & $\mathrm{H}$ & -0.31731 & .46651 & 0.30601 & $\mathrm{H}$ & 110 & 8783 & 1.09826 & $\mathrm{H}$ & -0.27917 & 0.78446 & 1.08867 \\
\hline $\mathrm{C}$ & 0 & 3 & 0. & e & 0. & -0. & 4334 & $\mathrm{C}$ & 779 & -0.13224 & -0.28470 & 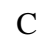 & & 535 & -0 . \\
\hline $\mathrm{O}$ & 0.86034 & -1.28579 & -0.62551 & $\mathrm{O}$ & 0.87823 & -1.27519 & -0.72075 & $\mathrm{O}$ & 443 & 1050 & 774 & 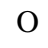 & 429 & 897 & 446 \\
\hline$C$ & 3.29341 & 2 & t. & & 3.30349 & 330 & & $\mathrm{C}$ & 2421 & 3222 & & & & & 010 \\
\hline $\mathrm{C}$ & 4.59807 & 0.80675 & -0.06278 & $\mathrm{C}$ & 144 & 838 & -0.04917 & $\mathrm{C}$ & 3312 & 7900 & 7789 & 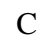 & 7689 & 9882 & .18486 \\
\hline $\mathrm{H}$ & 951 & 33 & -1.03195 & & 205 & 5 & 100 & $\mathrm{H}$ & 1 & & -0 & $\mathrm{H}$ & 5000 & 00 & -0 . \\
\hline $\mathrm{H}$ & 4 & & & 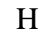 & 66 & & & & 2868 & & & I & & & .90481 \\
\hline $\mathrm{C}$ & 27 & 79 & 777 & $c$ & 99 & 9 & 54 & $\mathrm{C}$ & 8 & 55 & 3 & 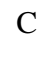 & 0 & -0 & 0.71164 \\
\hline 11 & 5.72167 & -0.90202 & .69115 & & 5.72624 & -0.89907 & 0.69328 & $\mathrm{H}$ & 5.90163 & -0.74258 & 8715 & & 0819 & -0.71544 & -0.06486 \\
\hline $\mathrm{H}$ & 45332 & 0.66725 & 987 & $\mathrm{H}$ & 75 & 8 & 44 & $\mathrm{H}$ & 6 & & & & 6.51165 & 0 & 1.04414 \\
\hline
\end{tabular}




\begin{tabular}{lrrr|rrr|rrr|rrr|rrr}
$\mathrm{H}$ & 5.03398 & 0.11846 & 1.96259 & $\mathrm{H}$ & 5.00061 & 0.08984 & 1.96989 & $\mathrm{H}$ & 5.22188 & -0.60125 & 1.54197 & $\mathrm{H}$ & 5.21956 & -0.56997 & 1.56022 \\
$\mathrm{O}$ & 3.42842 & -1.15601 & -0.70631 & $\mathrm{O}$ & 3.44542 & -1.12661 & -0.78547 & $\mathrm{O}$ & 3.50536 & -0.47250 & -1.37193 & $\mathrm{O}$ & 3.51348 & -0.46885 & -1.36012 \\
$\mathrm{H}$ & 2.50765 & -1.52812 & -0.79075 & $\mathrm{H}$ & 2.52410 & -1.49362 & -0.88718 & $\mathrm{H}$ & 2.60655 & -0.84072 & -1.59614 & $\mathrm{H}$ & 2.61755 & -0.84343 & -1.58523 \\
$\mathrm{C}$ & 2.07774 & 0.64780 & 0.01071 & $\mathrm{C}$ & 2.08274 & 0.63844 & 0.00229 & $\mathrm{C}$ & 2.09926 & 0.52904 & 0.24543 & $\mathrm{C}$ & 2.09534 & 0.53547 & 0.24500 \\
$\mathrm{H}$ & 2.02883 & 1.66302 & 0.38051 & $\mathrm{H}$ & 2.02528 & 1.63772 & 0.41167 & $\mathrm{H}$ & 2.00986 & 1.18836 & 1.09783 & $\mathrm{H}$ & 1.99882 & 1.19908 & 1.09328
\end{tabular}

Figure S1. Molecular graphs at the B3LYP/6-311++G(d,p) computational level in the gas phase for A-P structures. Green and red dot corresponds to the BCPs and ring critical points, respectively.

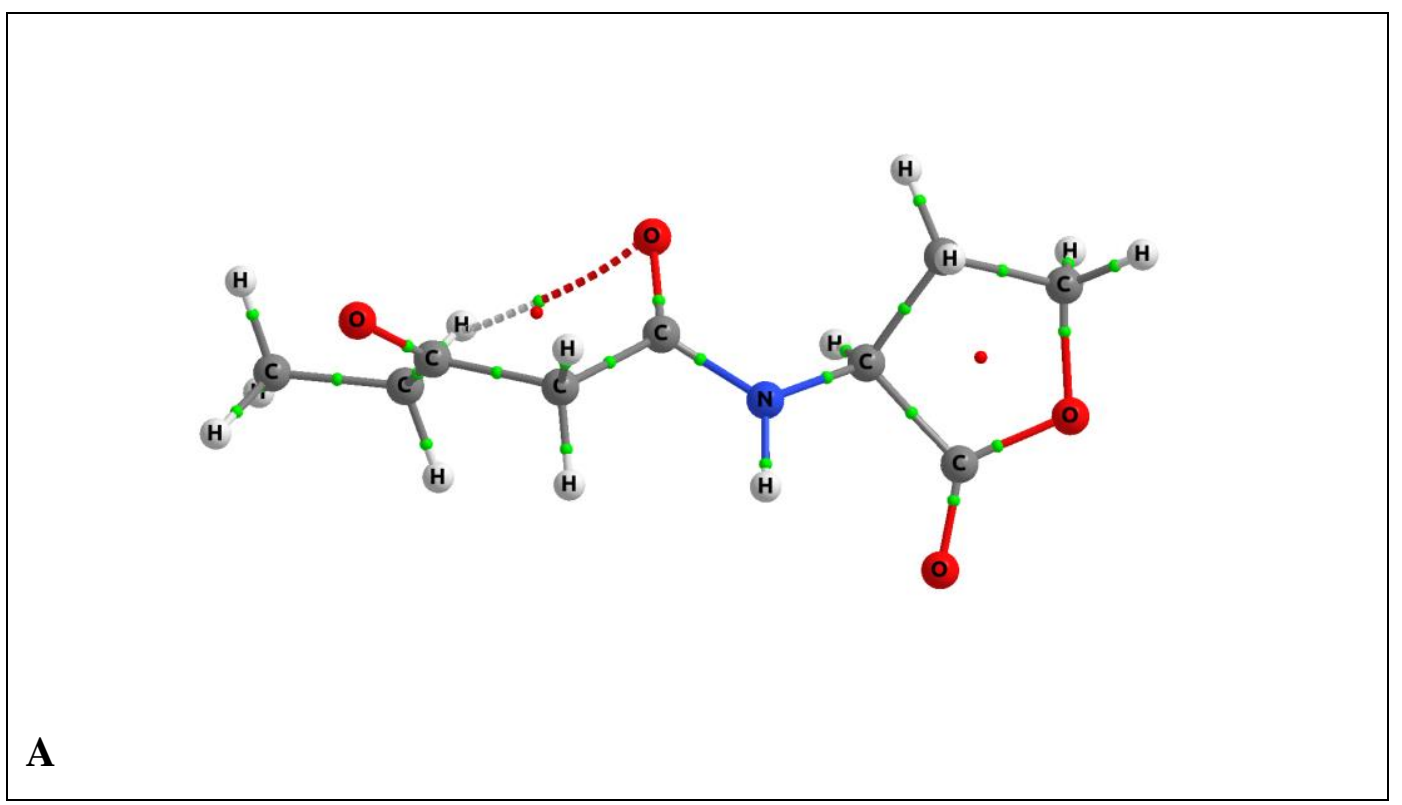




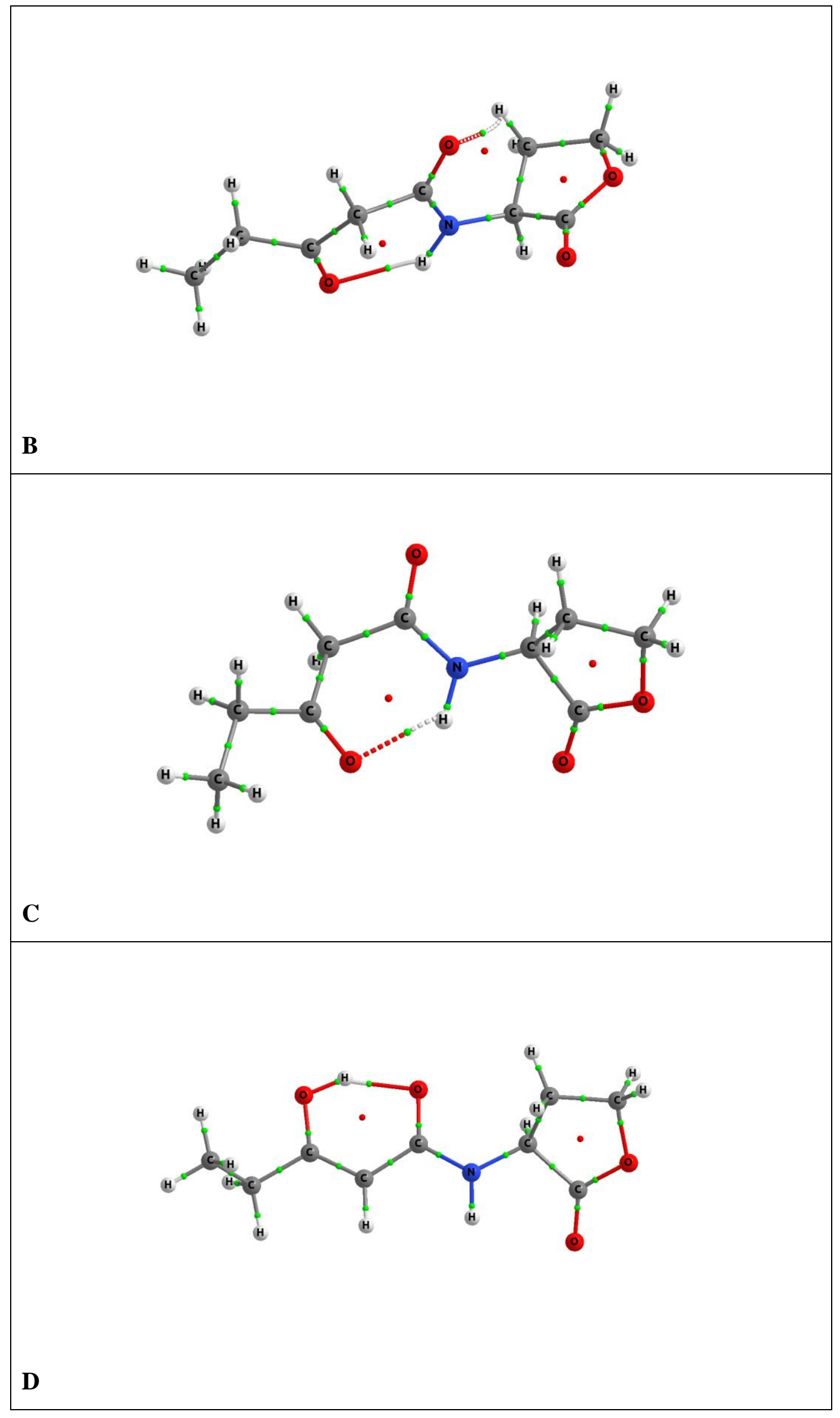




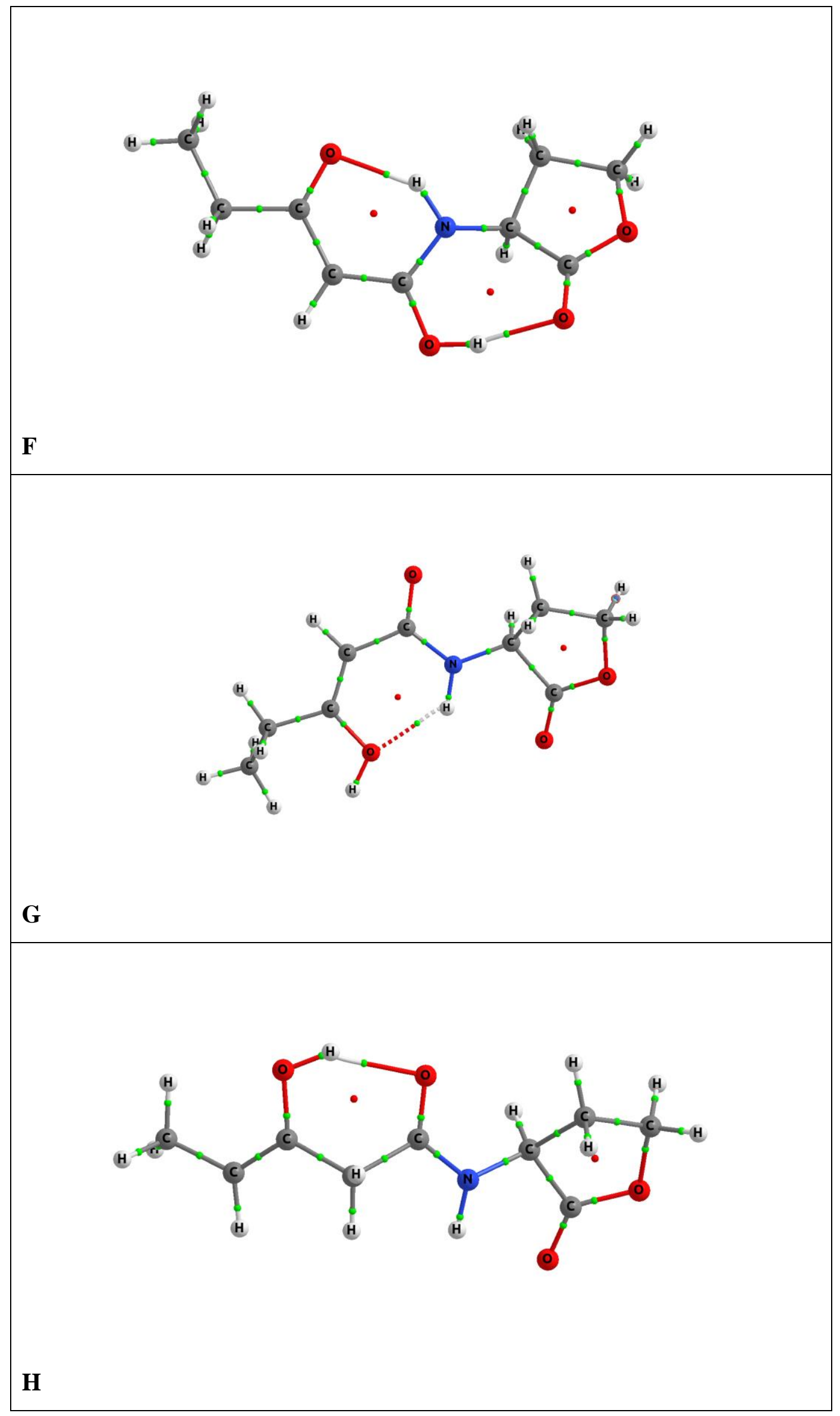




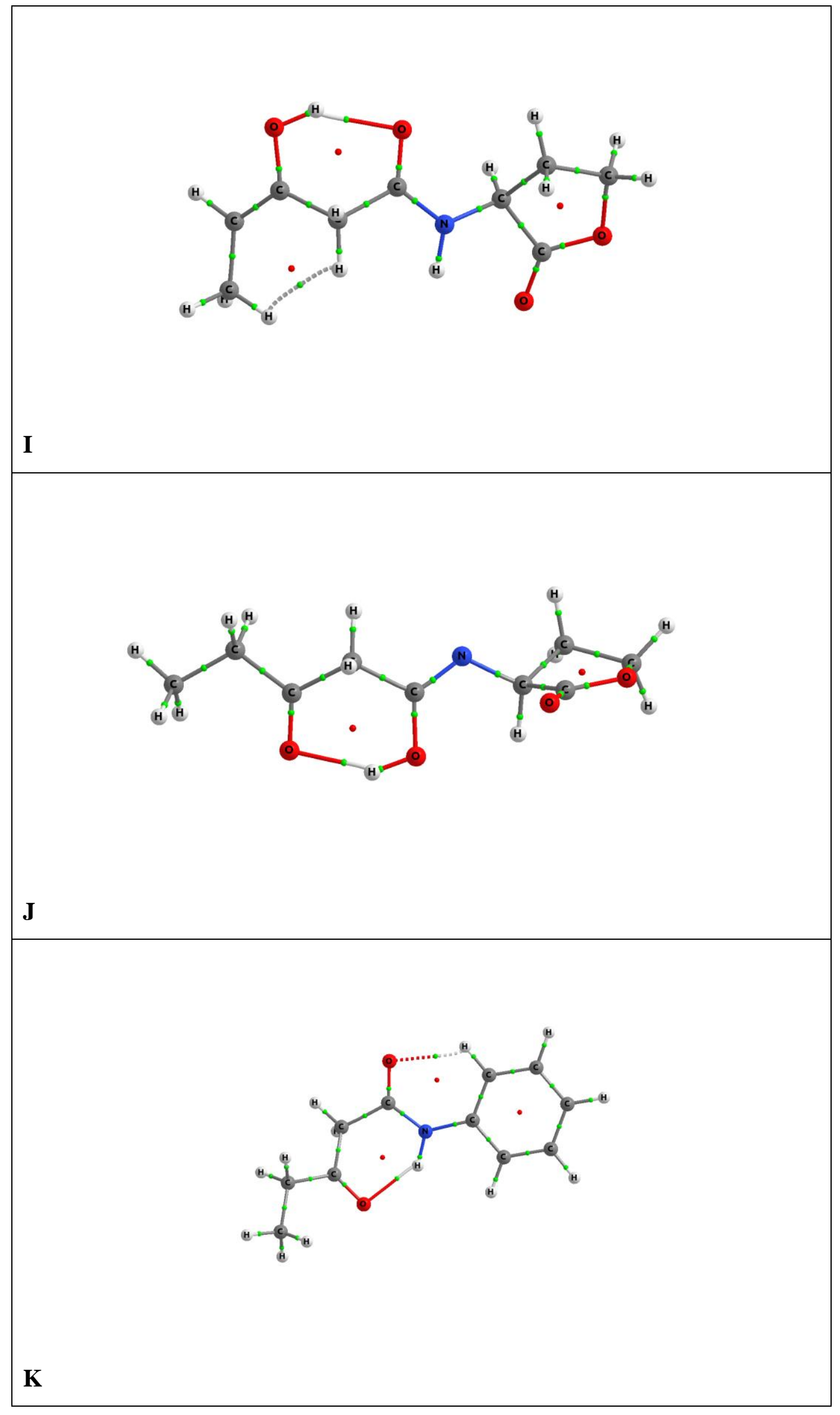




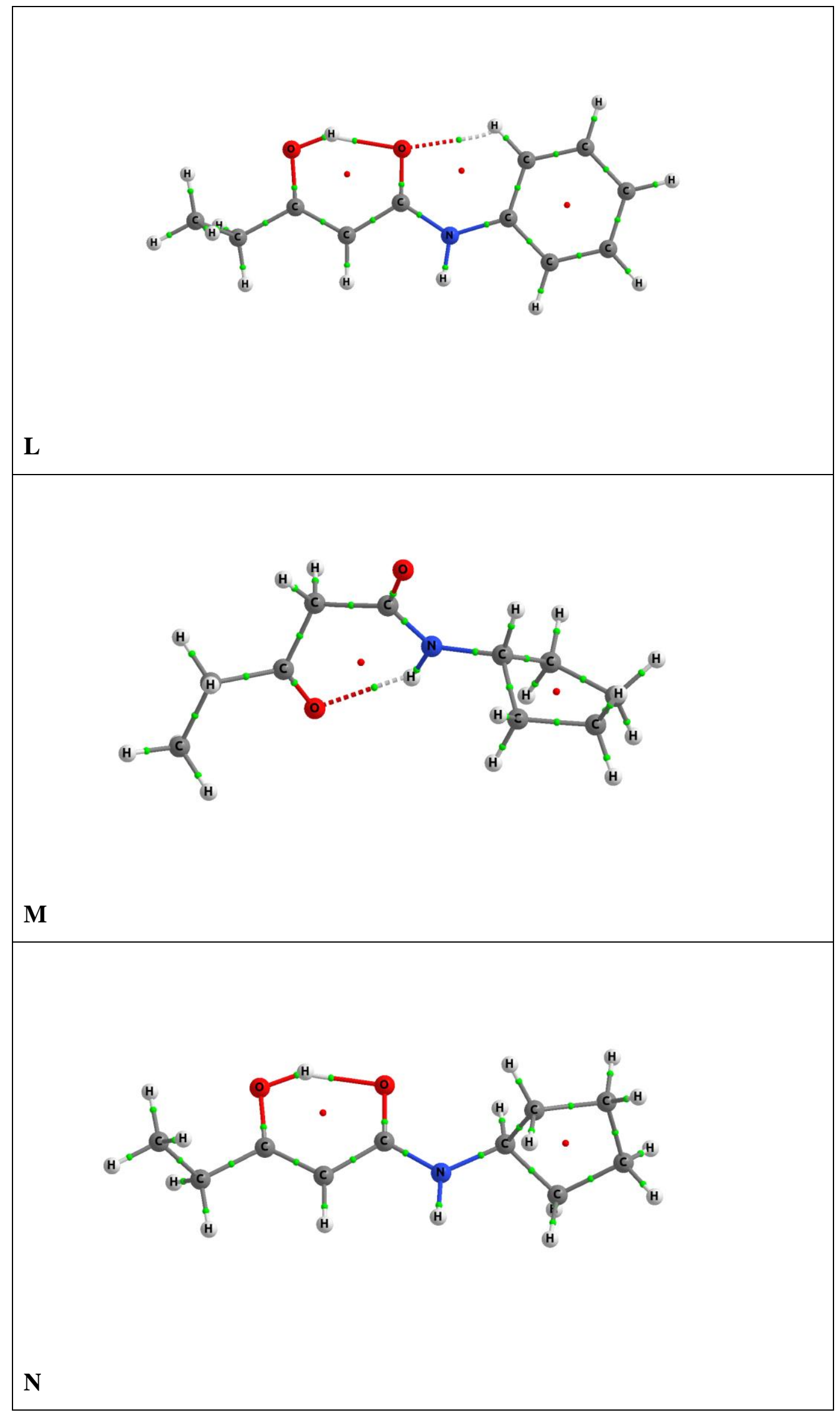




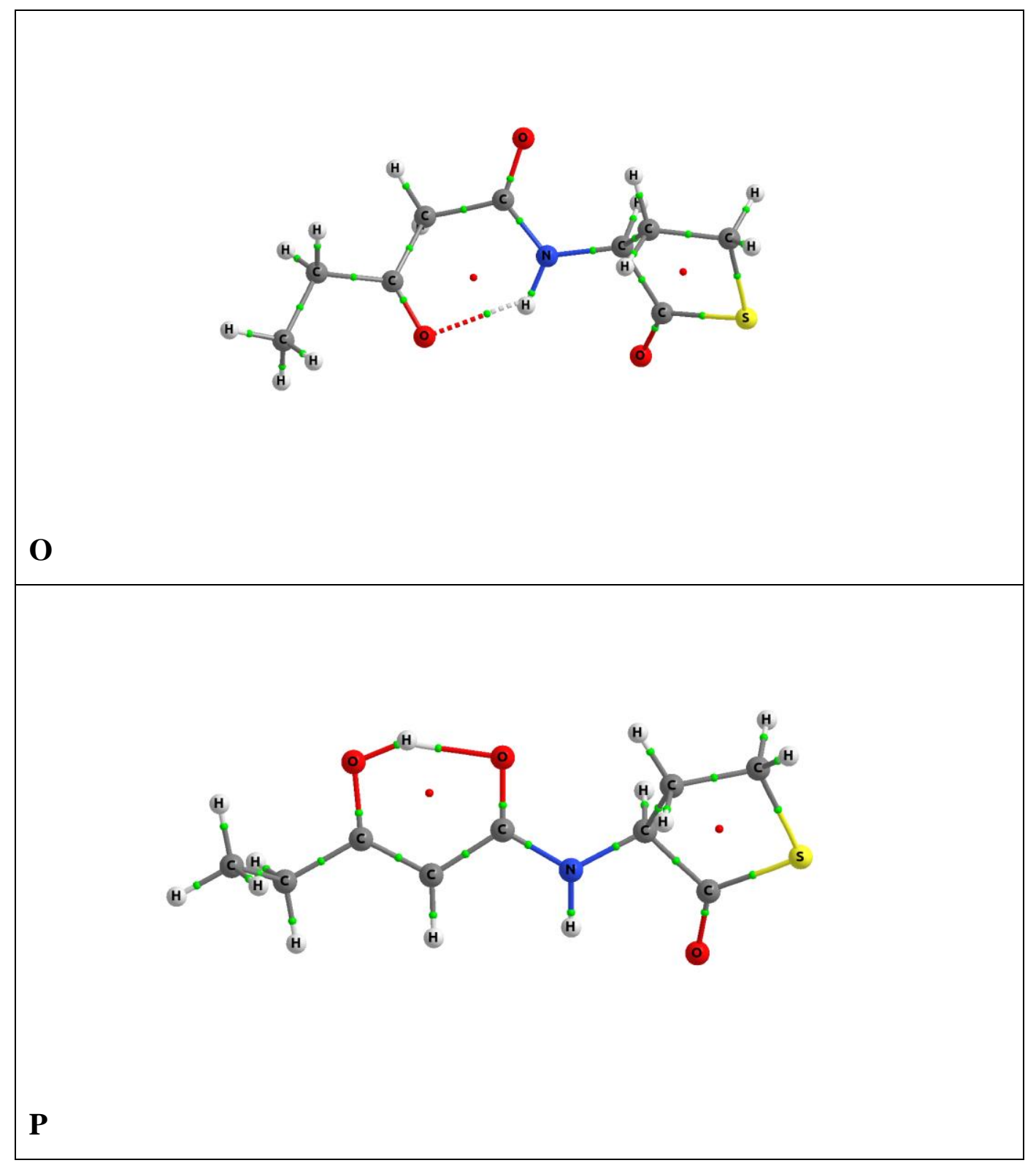




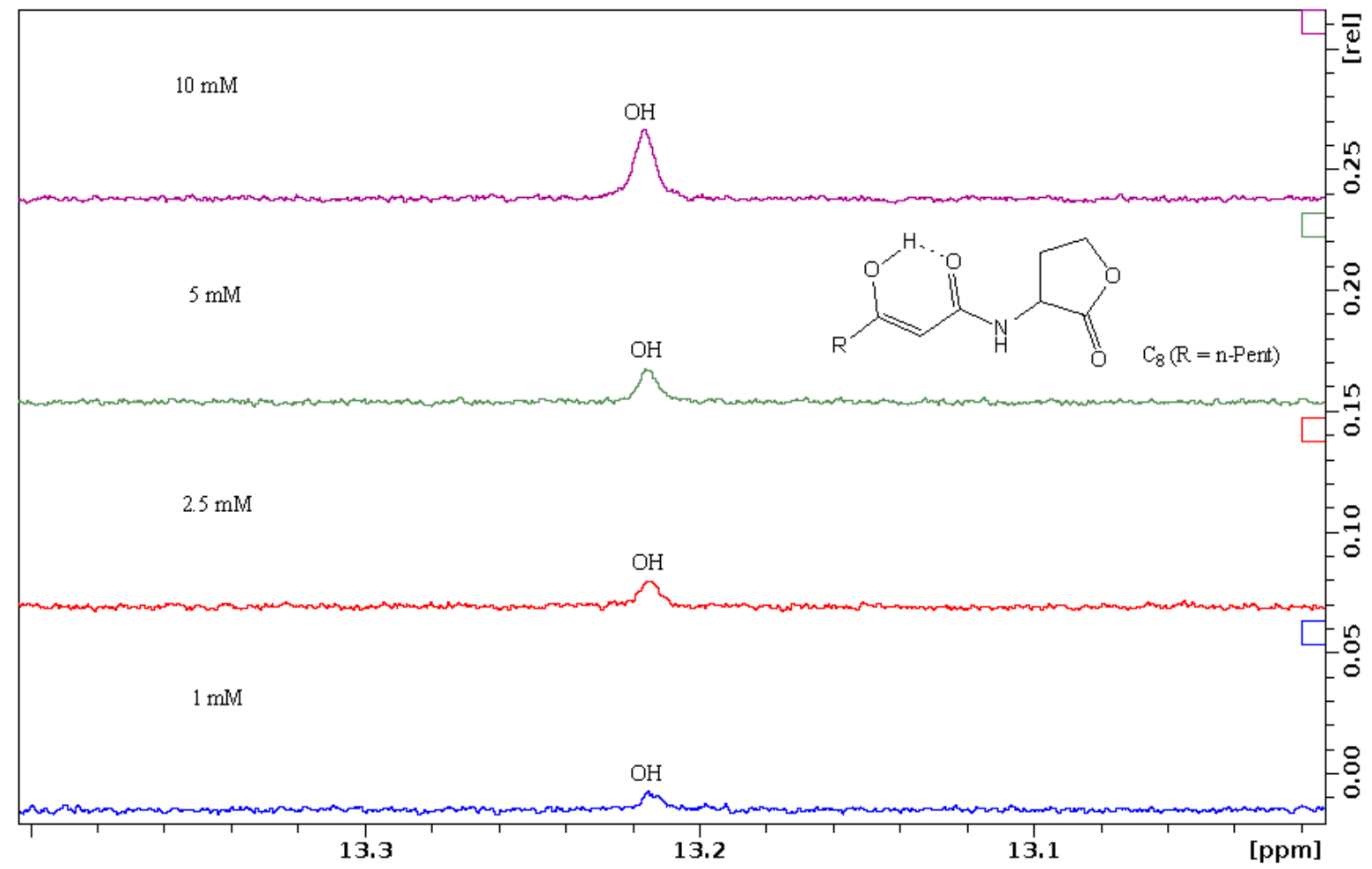

Figure S2. ${ }^{1} \mathrm{H}$ NMR stack of $\mathrm{C}_{8}-\mathrm{OHL} \mathrm{O}-\mathrm{H}$ region at $1-10 \mathrm{mM}$ concentrations in $\mathrm{CDCl}_{3}$

Table S1. Type of intramolecular interaction, $\mathrm{H} \cdots \mathrm{O}$ distance (in $\AA$ ), $\mathrm{Y}-\mathrm{H} \cdots \mathrm{O}$ angle (in ${ }^{\circ}$ ), electron density, $\rho_{\mathrm{BCP}}$, Laplacian, $\nabla_{\mathrm{BCP}}^{2}$, and total electron energy, $\mathrm{H}_{\mathrm{BCP}}$, at the bond critical point (in a.u.) and second order perturbation energy, E(2) (in $\mathrm{kcal} / \mathrm{mol}$ ) at the B3LYP/6-311++G(d,p) computational level in the gas phase (GP) and in acetonitrile (AC) for the $\mathbf{C}-\mathbf{J}$ structures.

\begin{tabular}{ccccccccc}
\hline Comp. & Type & $\mathrm{R}_{\mathrm{H} \cdots \mathrm{O}}$ & Angle & $\rho_{\mathrm{BCP}}$ & $\nabla_{\text {BCP }}^{2}$ & $\mathrm{H}_{\mathrm{BCP}}$ & $\mathrm{E}(2) \mathrm{GP}$ & $\mathrm{E}(2) \mathrm{AC}$ \\
\hline $\mathbf{C}$ & $\mathrm{N}-\mathrm{H} \cdots \mathrm{O}$ & 2.049 & 128.2 & 0.0224 & 0.0832 & 0.0024 & 4.8 & 7.7 \\
$\mathbf{D}$ & $\mathrm{O}-\mathrm{H} \cdots \mathrm{O}$ & 1.674 & 147.9 & 0.0515 & 0.1421 & -0.0074 & 25.7 & 26.4 \\
F & $\mathrm{O}-\mathrm{H} \cdots \mathrm{O}$ & 1.764 & 163.6 & 0.0391 & 0.1219 & -0.0018 & 18.0 & 21.5 \\
& $\mathrm{~N}-\mathrm{H} \cdots \mathrm{O}$ & 1.776 & 141.1 & 0.0418 & 0.1316 & -0.0019 & 18.6 & 14.4 \\
$\mathbf{G}$ & $\mathrm{N}-\mathrm{H} \cdots \mathrm{O}$ & 2.026 & 127.8 & 0.0213 & 0.0906 & 0.0032 & 3.7 & 4.6 \\
$\mathbf{H}$ & $\mathrm{O}-\mathrm{H} \cdots \mathrm{O}$ & 1.902 & 143.0 & 0.0299 & 0.1013 & 0.0007 & 8.6 & 11.8 \\
$\mathbf{I}$ & $\mathrm{O}-\mathrm{H} \cdots \mathrm{O}$ & 1.900 & 143.4 & 0.0115 & 0.0392 & 0.0018 & 8.6 & 11.8 \\
J & $\mathrm{O}-\mathrm{H} \cdots \mathrm{O}$ & 1.811 & 144.8 & 0.0369 & 0.1191 & -0.0011 & 13.5 & 17.7
\end{tabular}

Table S2. Type of intramolecular interaction, $\mathrm{H} \cdots \mathrm{O}$ distance (in $\AA$ ), $\mathrm{Y}-\mathrm{H} \cdots \mathrm{O}$ angle (in ${ }^{\circ}$ ), electron density, $\rho_{\mathrm{BCP}}$, Laplacian, $\nabla_{\mathrm{BCP}}^{2}$, and total electron energy, $\mathrm{H}_{\mathrm{BCP}}$, at the 
bond critical point (in a.u.) the B3LYP/6-311++G(d,p) computational level in the gas phase (GP) and in acetonitrile (AC) for the K-P structures.

\begin{tabular}{cccccccr}
\hline \multicolumn{7}{c}{ Gas phase } \\
\hline Comp. & Type & $\mathrm{R}_{\mathrm{H} \cdots \mathrm{O}}$ & Angle & $\rho_{\mathrm{BCP}}$ & $\nabla^{2}{ }_{\mathrm{BCP}}$ & \multicolumn{1}{c}{$\mathrm{H}_{\mathrm{BCP}}$} & \multicolumn{1}{c}{$\mathrm{E}(2)$} \\
\hline $\mathbf{K}$ & $\mathrm{N}-\mathrm{H} \cdots \mathrm{O}$ & 1.968 & 136.5 & 0.0263 & 0.0957 & 0.0022 & 7.10 \\
$\mathbf{L}$ & $\mathrm{O}-\mathrm{H} \cdots \mathrm{O}$ & 1.671 & 147.7 & 0.0519 & 0.1430 & -0.0076 & 25.96 \\
$\mathbf{M}$ & $\mathrm{N}-\mathrm{H} \cdots \mathrm{O}$ & 2.035 & 132.7 & 0.0229 & 0.0840 & 0.0023 & 5.06 \\
$\mathbf{N}$ & $\mathrm{O}-\mathrm{H} \cdots \mathrm{O}$ & 1.655 & 148.5 & 0.0540 & 0.1443 & -0.0087 & 28.12 \\
$\mathbf{O}$ & $\mathrm{N}-\mathrm{H} \cdots \mathrm{O}$ & 2.047 & 128.4 & 0.0225 & 0.0835 & 0.0024 & 4.92 \\
$\mathbf{P}$ & $\mathrm{O}-\mathrm{H} \cdots \mathrm{O}$ & 1.673 & 147.9 & 0.0516 & 0.1422 & -0.0074 & 25.81 \\
\hline & & \multicolumn{7}{c}{ Acetonitrile } & & & \\
\hline Comp. & Type & $\mathrm{R}_{\mathrm{H} \cdots \mathrm{O}}$ & Angle & $\rho_{\mathrm{BCP}}$ & $\nabla^{2}{ }_{\mathrm{BCP}}$ & $\mathrm{H}_{\mathrm{BCP}}$ & $\mathrm{E}(2)$ \\
\hline $\mathbf{K}$ & $\mathrm{N}-\mathrm{H} \cdots \mathrm{O}$ & 1.919 & 138.3 & 0.0293 & 0.1052 & 0.0018 & 9.15 \\
$\mathbf{L}$ & $\mathrm{O}-\mathrm{H} \cdots \mathrm{O}$ & 1.666 & 148.6 & 0.0526 & 0.1440 & -0.0079 & 26.66 \\
$\mathbf{M}$ & $\mathrm{N}-\mathrm{H} \cdots \mathrm{O}$ & 1.998 & 134.1 & 0.0249 & 0.0908 & 0.0022 & 6.13 \\
$\mathbf{N}$ & $\mathrm{O}-\mathrm{H} \cdots \mathrm{O}$ & 1.645 & 149.7 & 0.0555 & 0.1460 & -0.0095 & 29.63 \\
$\mathbf{O}$ & $\mathrm{N}-\mathrm{H} \cdots \mathrm{O}$ & 1.960 & 134.2 & 0.0269 & 0.0984 & 0.0021 & 7.28 \\
$\mathbf{P}$ & $\mathrm{O}-\mathrm{H} \cdots \mathrm{O}$ & 1.666 & 148.7 & 0.0525 & 0.1437 & -0.0079 & 26.78
\end{tabular}

\section{References}

1. Frisch, M. J.; Trucks, G. W.; Schlegel, H. B.; Scuseria, G. E.; Robb, M. A.; Cheeseman, J. R.; Scalmani, G.; Barone, V.; Mennucci, B.; Petersson, G. A.; Nakatsuji, H.; Caricato, M.; Li, X.; Hratchian, H. P.; Izmaylov, A. F.; Bloino, J.; Zheng, G.; Sonnenberg, J. L.; Hada, M.; Ehara, M.; Toyota, K.; Fukuda, R.; Hasegawa, J.; Ishida, M.; Nakajima, T.; Honda, Y.; Kitao, O.; Nakai, H.; Vreven, T.; Montgomery, J., J. A.; Peralta, J. E.; Ogliaro, F.; Bearpark, M.; Heyd, J. J.; Brothers, E.; Kudin, K. N.; Staroverov, V. N.; Kobayashi, R.; Normand, J.; Raghavachari, K.; Rendell, A.; Burant, J. C.; Iyengar, S. S.; Tomasi, J.; Cossi, M.; Rega, N.; Millam, N. J.; Klene, M.; Knox, J. E.; Cross, J. B.; Bakken, V.; Adamo, C.; Jaramillo, J.; Gomperts, R.; Stratmann, R. E.; Yazyev, O.; Austin, A. J.; Cammi, R.; Pomelli, C.; Ochterski, J. W.; Martin, R. L.; Morokuma, K.; Zakrzewski, V. G.; Voth, G. A.; Salvador, P.; Dannenberg, J. J.; Dapprich, S.; Daniels, A. D.; Farkas, Ö.; Foresman, J. B.; Ortiz, J. V.; Cioslowski, J.; Fox, D. J. Gaussian 09, Revision d1, Inc.: Wallingford CT, 2009.

2. Bader, R. F. W., Atoms in Molecules: A Quantum Theory. Clarendon Press: Oxford, 1990. 
3. Popelier, P. L. A., Atoms In Molecules. An Introduction. Prentice Hall: Harlow, England, 2000.

4. Keith, T. A. AIMAll, TK Gristmill Software Version 15.09.27, 2015.

5. $\quad$ Reed, A. E.; Curtiss, L. A.; Weinhold, F. Chem. Rev. 1988, 88, 899.

6. Johnson, E. R.; Keinan, S.; Mori-Sanchez, P.; Contreras-Garcia, J.; Cohen, A. J.; Yang, W., Revealing Noncovalent Interactions. J. Am. Chem. Soc. 2010, 132,6498 .

7. Humphrey, W.; Dalke, A.; Schulten, K. J. Mol. Graph. 1996, 14, 33. 